\title{
Seychelles: 2008 Article IV Consultation and Request for a Stand-By Arrangement- Staff Report; Staff Supplement; Public Information Notice and Press Release on the Executive Board Discussion; and Statement by the Executive Director for Seychelles
}

\begin{abstract}
Under Article IV of the IMF's Articles of Agreement, the IMF holds bilateral discussions with members, usually every year. In the context of a combined discussion of the 2008 Article IV consultation with Seychelles and Request for a Stand-By Arrangement, the following documents have been released and are included in this package:
\end{abstract}

- $\quad$ The staff report for the combined 2008 Article IV Consultation and Request for a Stand-By Arrangement, prepared by a staff team of the IMF, following discussions that ended on September 19, 2008, with the officials of Seychelles on economic developments and policies. Based on information available at the time of these discussions, the staff report was completed on October 31, 2008. The views expressed in the staff report are those of the staff team and do not necessarily reflect the views of the Executive Board of the IMF.

- $\quad$ Staff supplement of November 12, 2008, updating information on recent economic developments.

- $\quad$ A Press Release and a Public Information Notice (PIN), summarizing the views of the Executive Board as expressed during its November 14, 2008, discussion of the staff report on issues related to the Article IV consultation and the IMF arrangement, respectively.

- $\quad$ A statement by the Executive Director for Seychelles.

The documents listed below have been or will be separately released.

Letter of Intent sent to the IMF by the authorities of Seychelles*

Memorandum of Economic and Financial Policies by the authorities of

Seychelles*

Technical Memorandum of Understanding*

*Also included in Staff Report

The policy of publication of staff reports and other documents allows for the deletion of market-sensitive information.

Copies of this report are available to the public from

International Monetary Fund • Publication Services

$70019^{\text {th }}$ Street, N.W. • Washington, D.C. 20431

Telephone: (202) 623-7430 • Telefax: (202) 623-7201

E-mail: publications@imf.org • Internet: http://www.imf.org

Price: $\$ 18.00$ a copy

\section{International Monetary Fund}

Washington, D.C. 



\title{
INTERNATIONAL MONETARY FUND
}

\section{SEYCHELLES \\ Staff Report for the 2008 Article IV Consultation and Request for a Stand-By Arrangement}

\author{
Prepared by the African Department \\ (in consultation with other departments)
}

\author{
Approved by Thomas Krueger (AFR) and Philip Gerson (SPR)
}

October 31, 2008

\begin{abstract}
Missions: Victoria, January 17-30, July 26-August 4, and September 5-19, and at headquarters October 9-15, 2008. Staff met with President Michel, Minister of Finance Faure, Minister of National Development Dugasse, Governor of the Central Bank of Seychelles Chang Leng, other senior government officials, and representatives of the private sector, civil society, and the diplomatic community.
\end{abstract}

January mission: Mr. Funke (head), Mr. Koehler, Ms. Medina Cas (all AFR), and Mr. Zeuner (PDR). Mr. Murray (Executive Director) and Ms. Tracey Lane (World Bank) participated in some of the policy discussions. July mission: Mr. Mathieu (head), Ms. Medina Cas (all AFR), Mr. Nielsen (PDR) and Mr. Duggan (OED). September mission: Mr. Mathieu (head), Ms. Deléchat, Ms. Medina Cas, Mr. Fernandez (all AFR), Mr. Atoyan (PDR), Mr. Baban (LEG), Ms. Polan, Mr. Bartholomew (both MCM). Mr. Rogers, Senior Resident Representative in Nairobi, Mr. Plant (AFR), Mr. Blitzer (MCM), and Mr. Duggan (OED) participated in part of the meetings.

At the last Article IV consultation, (for 2006 on March 23, 2007), Directors encouraged the authorities to implement more thorough reforms, in order to reduce vulnerabilities decisively and enhance growth prospects and competitiveness. They observed that exchange market liberalization could set the stage for the elimination of restrictions on the making of payments and transfers for current international transactions that are subject to Fund approval under Article VIII, and they looked forward to further progress in this area.

The authorities are requesting a two-year SBA with access at 200 percent of quota (SDR 17.6 million), frontloaded with an initial disbursement of 70 percent of quota to cover remaining financing needs for 2008, available upon approval of the arrangement. The program aims at restoring macroeconomic stability through (i) a fundamental liberalization of the exchange regime supported by a reform of the monetary policy framework; (ii) a significant and sustained fiscal tightening complemented by a comprehensive debt restructuring; and (iii) reinforced governance and a reduced role of the state in the economy.

Seychelles accepted the obligations of Article VIII, sections 2, 3, and 4. The de facto exchange regime was a peg to a single currency until a managed float was announced on October 31, effective November 3, 2008, at which time the remaining restrictions on the making of payments and transfers for current international transactions subject to Fund jurisdiction under Article VIII were eliminated.

A safeguards assessment mission was conducted in September 2008. It found high risks in all areas of the central bank (CBS) safeguards assessment framework, including significant weaknesses in financial reporting that were not identified by the external auditor and internal control vulnerabilities. The authorities agreed to implement remedial measures, including the rapid hiring of new external auditors, and steps to be monitored under the program. 


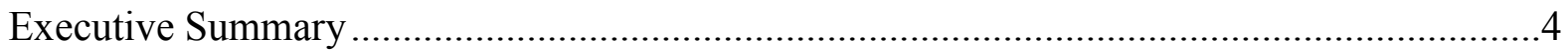

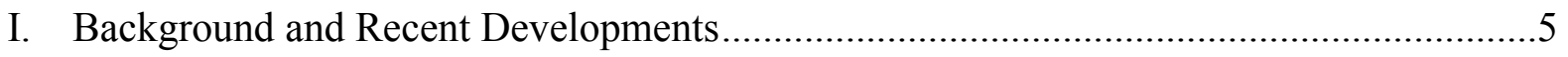

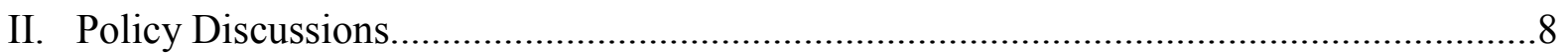

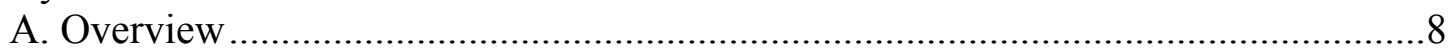

B. Macroeconomic Framework .................................................................... 9

C. Exchange Regime Reform and Exchange Rate Policy ....................................10

D. Restoring Public Debt Sustainability ................................................................14

E. Reforming Monetary Policy and Maintaining Financial Sector Stability ..............17

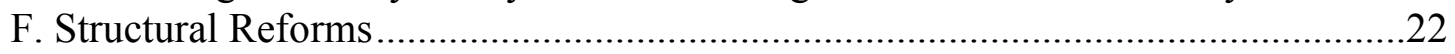

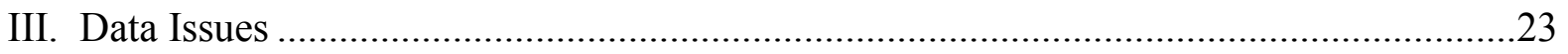

IV. Program Design, Financing and Risks.....................................................................24

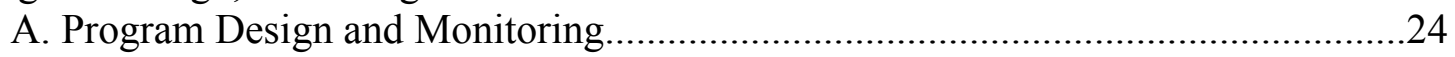

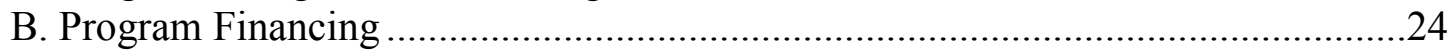

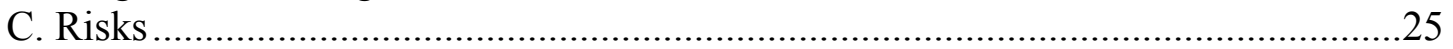

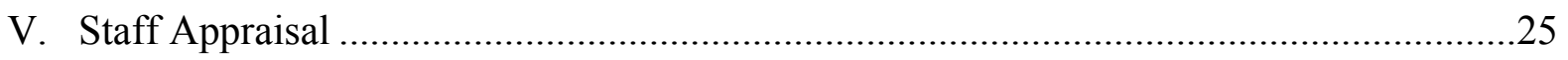

Boxes

1. External Stability and Exchange Rate Assessment..................................................... 13

2. Financial Sector Vulnerabilities and Stress-Testing Results .......................................... 21

Figures

1. Selected Economic Indicators, 2001-08 .................................................................. 7

2. Official Versus Parallel Exchange Rate Developments, Jan.-Sept. 2008 .......................11

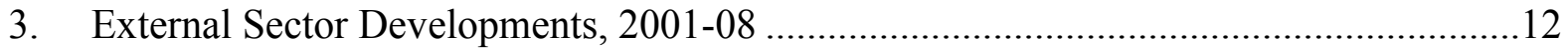

4. Selected Small-State Indicators, 2002-08 ................................................................... 16

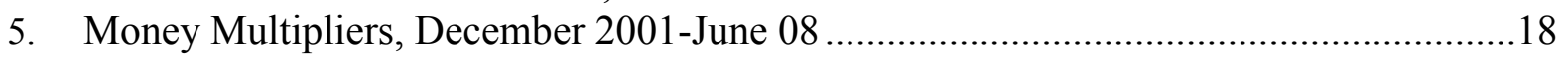

6. Financial Sector Developments, 2001-08 ............................................................20

Tables

1. Selected Economic and Financial Indicators, 2005-13 ............................................28

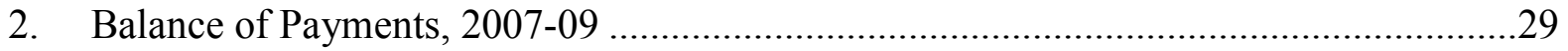

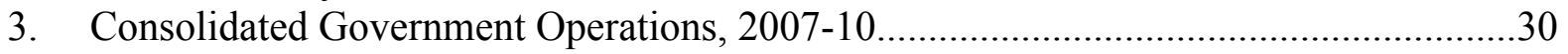

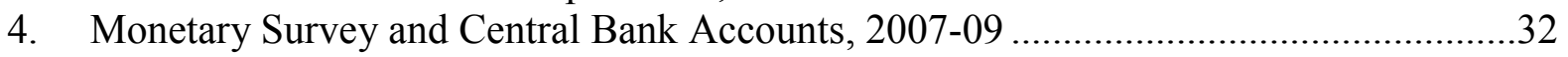

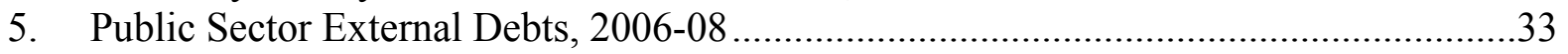

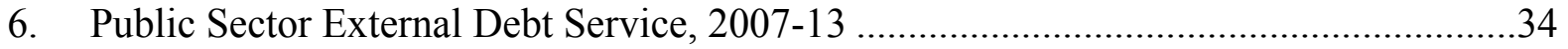

7. Financial Soundness Indicators for the Banking Sector, 2002-08 ..............................35

8. Balance of Payments, 2007-18 ..................................................................................36

9. Fund Disbursements and Timing of Reviews Under the Prospective Two-Year

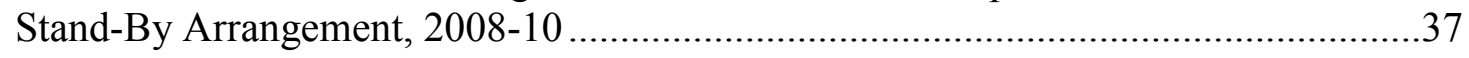

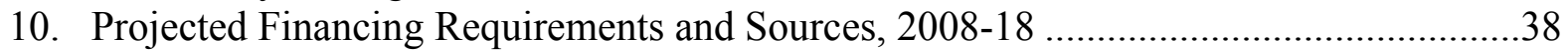

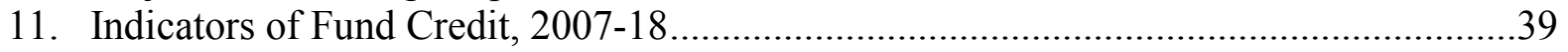


Appendices

I. Letter of Intent.

Attachment I. Memorandum of Economic and Financial Policies for 2008-09 ..........42

Attachment II. Technical Memorandum of Understanding .....................................57

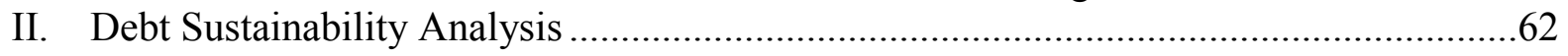




\section{EXECUTIVE SUMMARY}

Seychelles is in the midst of an acute balance of payments and public debt crisis, which jeopardizes its high living standards and economic development. Large macroeconomic imbalances and vulnerabilities resulting from longstanding unsustainable macroeconomic policies, combined with recent external shocks, culminated in mid 2008 with the nearexhaustion of foreign reserves and missed payments on public debt obligations. Growth is declining and inflation has risen sharply. The pegged exchange rate that was incompatible with fundamentals, together with a complex system of exchange restrictions and controls, has resulted in economic dislocation, a parallel exchange market, and pervasive dollarization.

The authorities have requested Fund assistance in support of a comprehensive reform strategy. Acknowledging that past piecemeal reform efforts have been insufficient to address imbalances and vulnerabilities, the authorities have begun implementing a package of major macroeconomic and structural reforms, including:

- A fundamental liberalization of the exchange regime, involving the elimination of all exchange restrictions and a float of the rupee;

- A significant and sustained tightening of fiscal policy backed by a reduction in public employment and the replacement of indirect subsidies by a targeted social safety net;

- $\quad$ A reform of the monetary policy framework to focus on liquidity management based on indirect instruments; and

- A reduction in the role of the state in the economy to boost private sector development, through further privatization, enhanced fiscal governance, and a review of the tax regime.

However, to put public debt on a sustainable path, the reform effort-notwithstanding its strength-will need to be complemented by a comprehensive public debt restructuring involving asubstantial reduction in the debt service burden consistent with the long-term ability to pay .

The reforms are heavily frontloaded, with the bulk of the fiscal adjustment and other key measures implemented in the fourth quarter of 2008. The turnaround in the primary fiscal balance from 2007 is about 8 percent of GDP in 2008, with sustained primary surpluses of about $6 \frac{1}{2}$ percent through 2011. Fiscal reforms also include the removal of tax exemptions, a strengthening of tax administration and of public financial management.

A comprehensive structural reform effort is needed to sustain growth and competitiveness over the medium-term. Together with Fund staff, the World Bank, and other partners, the authorities intend to elaborate a well-articulated medium-term structural reform agenda in 2009 and have indicated their intention to seek later support for these reforms under a successor EFF arrangement.

In view of the strength of the proposed policies, staff recommends approval of the authorities' request for Fund support of their reform efforts through a two-year SBA in the amount of SDR 17.6 million (200 percent of quota). 


\section{BACKGROUND AND RECENT DEVELOPMENTS}

1. Seychelles is in the midst of an acute balance of payments and public debt crisis, which jeopardizes its high living standards and economic development. Expansionary fiscal and monetary policies have been incompatible with the maintenance of the pegged exchange rate for some years and despite step devaluations in 2006-07. A system of complex exchange controls and restrictions were progressively introduced and foreign exchange shortages ensued. The parallel exchange market flourished (the parallel market premium was over 50 percent) and dollarization rose. Competitiveness and growth deteriorated as the real effective exchange rate exchange became increasingly overvalued (Figure 1).

2. The authorities introduced a number of reforms starting in 2003 with a fiscal adjustment and a gradual liberalization of the economy. In October 2006, they issued a US\$200 million Eurobond and began a sizable depreciation of the rupee over the next twelve months. In 2007, the authorities launched the medium-term development plan "Seychelles Strategy 2017", aiming at a doubling of nominal per-capita income in ten years and a reduction of public debt to 60 percent of GDP. In late 2007 they issued a private placement note for $€ 54.7$ million and a US\$30 million supplement to the Eurobond to pay for the clearance of the backlog of unremitted profits by foreign investors.

3. However, the gradual and piecemeal reform effort has been insufficient to address longstanding macroeconomic imbalances. The fuel and food price shocks and the global economic slowdown exacerbated existing vulnerabilities (Table 1):

- $\quad$ Foreign exchange shortages-disrupting manufacturing output-and less buoyant tourism growth are expected to lead to a sharp decline in real GDP growth in 2008, to 3.1 percent from an average of about 7.5 percent of GDP in 2005-07.

- Inflation has risen rapidly, in part as a result of the 2006-07 nominal depreciation of the rupee, up to 37.5 percent (year-on-year) at end-August 2008, compared to 5.2 percent in August 2007, and virtually zero in 2005-06.

- $\quad$ The external current account deficit is projected to widen in 2008, from 23 percent of GDP in 2007 to almost 29 percent, due to lower growth in tourism receipts, the petroleum an food price shock, and higher costs of transportation services. As of midOctober official reserves had fallen to about US\$14 million, and the balance of payments is increasingly financed by external arrears accumulation (Table 2).

4. In light of these developments, in $\mathbf{2 0 0 8}$ the authorities began to tighten fiscal and monetary policy:

- $\quad$ The 2008 budget has been implemented broadly as approved, and further tightened in October, implying a substantial correction (Table 3). Compared to a 2.3 percent deficit in 2007, the primary surplus is now projected at 5.6 percent of GDP in 2008 (excluding a 1.5 percent of GDP transfer of valuation gains from the central bank). 
- $\quad$ In June 2008, the Central Bank of Seychelles (CBS) raised reserve requirements significantly. However, the local asset ratio (LAR-met only by holding domestic treasury securities) was reduced, offsetting in part the increase in reserve requirements. Broad money growth remained high at end-September 2008 (20.4 percent, year-on-year) (Table 4).

5. At almost 151 percent of GDP, public debt is unsustainable. External public debt represents some 98 percent of GDP (US\$808 million), of which some US\$313 million is arrears, mostly to Paris Club creditors and on the privately placed amortizing notes that the authorities stopped servicing in July 2008 (Tables 5 and 6). There is a small amount of arrears (US\$2.2 million) to multilateral creditors. In October 2008, facing near exhaustion of international reserves, the authorities announced that they would not be able to make a coupon payment on the US\$230 million of Eurobond, and indicated that they would approach creditors to seek an agreement on a comprehensive debt restructuring. Standard and Poor's has downgraded Seychelles to SD (selective default).

\section{Commercial banks are adequately capitalized and have long net open positions} in foreign exchange, but are vulnerable to interest rate and credit default risk. As of end-June 2008, banking industry assets totaled about SR 8.8 billion (113 percent of GDP). Domestic lending accounted for only about 25 percent of assets with most funds invested abroad (34 percent), and in domestic government securities ( 24 percent). Bank regulatory capital, measured on the most stringent capitalization measure - capital net of all provisions for loan loss and intangibles - stood at 5.6 percent of net assets -40 basis points short of being considered well capitalized. However, banks' large exposure to government securities makes them highly vulnerable to declines in the values of those investments. Whereas industry capital as of June 30,2008, covered about 22 percent of holdings of government securities, three banks had coverage of only 11-14 percent (Table 7). 


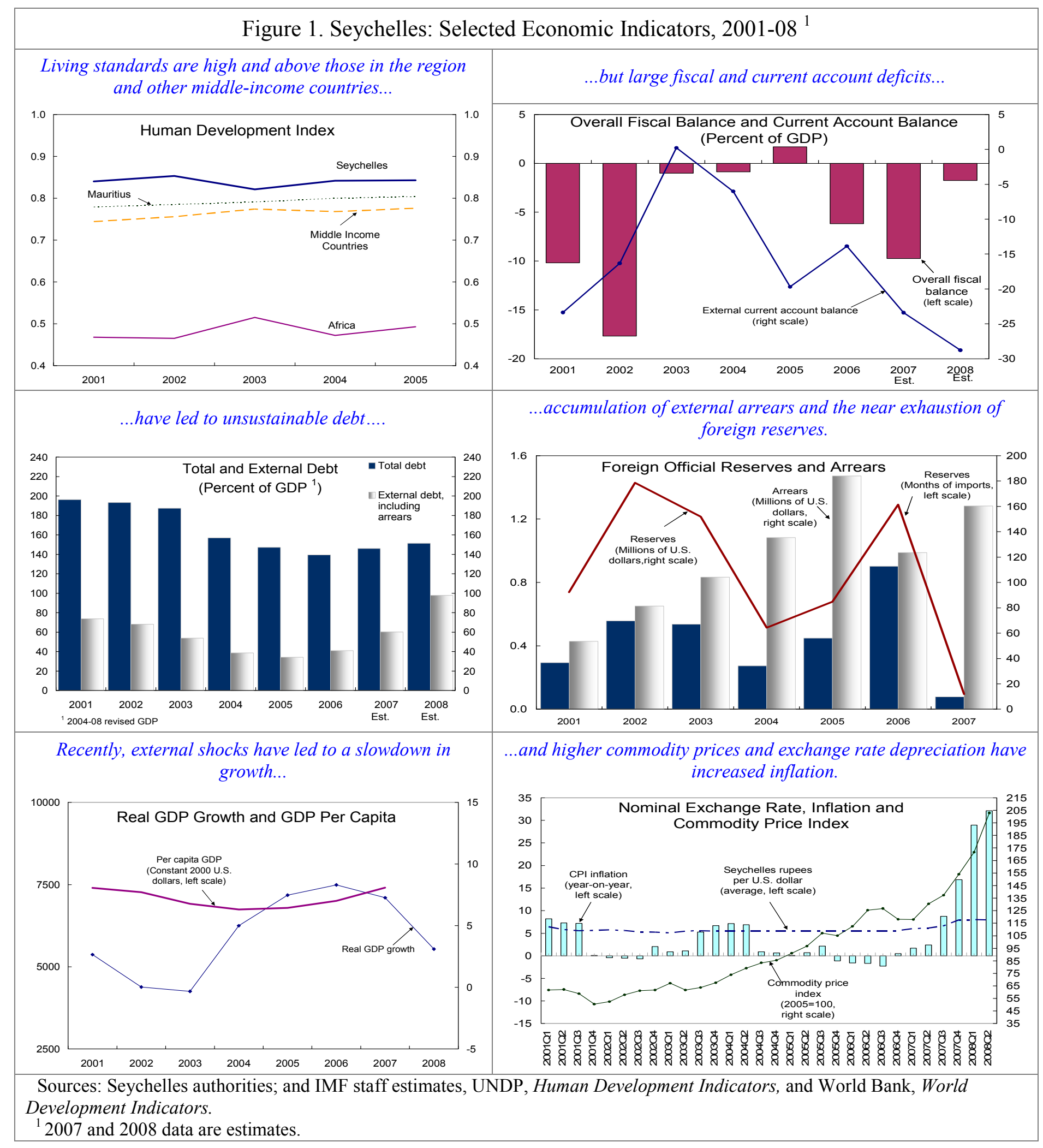




\section{Policy Discussions}

\section{A. Overview}

7. A strong political consensus in favor of a coherent reform effort emerged in mid2008. Previous Article IV consultation discussions have highlighted Seychelles' significant vulnerabilities, including from an overvalued exchange rate, and recommended a comprehensive reform effort but at the time the authorities favored a more gradual approach. President Michel's popular mandate, support from the ruling party's electoral base and a broad-based realization that the current policies are unsustainable have given the government the needed support to break with the past.

\section{Program discussions focused on a package of policies aiming at restoring} internal and external stability, with strong ownership on the part of the authorities. In particular, the authorities are committed to implementing far-reaching reforms to resolve the longstanding macroeconomic imbalances, address an overvalued exchange rate, and place public debt on a sustainable path. The key elements of the program are the following:

- $\quad$ Achieve full convertibility of the Seychelles rupee and introduce a floating exchange rate regime. The removal of all exchange restrictions and introduction of a marketbased float of the rupee will play a key role in the improvement of external competitiveness and reduction in macroeconomic imbalances.

- $\quad$ Sustain a significant fiscal tightening to address the macroeconomic imbalances, underpin competitiveness gains and put public debt on a sustainable path.

- $\quad$ Reform monetary policy to focus on liquidity management with market-based instruments. A floating exchange rate regime places increased emphasis on monetary policy to achieve price stability. At the same time, maintaining financial system stability in the aftermath of the reforms will require enhanced bank supervision.

- $\quad$ Reduce the role of the state in the economy and improve the business environment. Steps to boost private sector investment and growth include privatization, the strengthening of monitoring and oversight of public entities; and enhancing transparency and governance.

9. However, these fundamental policy reforms are not sufficient in themselves to put Seychelles' public debt on a sustainable footing. Paris Club creditors have informally indicated their willingness to considering treatment of Seychelles' debt under the Evian approach. The authorities are working on a debt restructuring strategy which would be consistent with Fund's lending into arrears policy, with focus on information transparency, intercreditor equity, and dialogue with all creditor groups. A large cash flow relief on external public debt service is needed in 2009-11. Regarding domestic debt, largely held by the domestic banking system and CBS, there is limited margin to absorb a nominal haircut. 


\section{B. Macroeconomic Framework}

\section{The medium-term macroeconomic framework is based on full implementation of the policies envisaged under the program (Text Table 1).}

- $\quad$ The global downturn and tight macroeconomic policies will lead to a contraction of GDP in 2009, by about 0.5 percent. A recovery is projected to emerge thereafter with average real GDP growth of about 5 percent from 2011, under the impulse of rising foreign investment in tourism following the lifting of exchange restrictions and other bottlenecks.

- $\quad$ The rupee depreciation following the float is expected to lead in the short-run to higher inflation, which would peak in the second quarter of 2009 and gradually decline to 22 percent at end-2009. The REER would depreciate on average in 2009, followed by a small appreciation.

- $\quad$ Together with a temporary decline in FDI-related imports, the rupee depreciation is projected to significantly improve the non-interest current account deficit in 2009 to 16.4 percent, from 26.6 percent in 2008 . The non-interest current account deficit should widen moderately over the medium term, as rising tourism earnings are offset by higher tourism- and FDI- related imports and greater profit and dividend repatriation. The program envisages relatively rapid accumulation of official foreign reserves, albeit from a very low base of 0.5 weeks of imports in 2008 to 10.4 weeks by 2011 (Table 8 ).

- Without a debt restructuring, total public debt would increase to 161 percent of GDP in 2009 and remain at unsustainably high levels over the medium term. Domestic debt would be expected to decline through a combination of fiscal restraint and the impact of negative real rates in 2008, especially on long term securities with fixed coupons. With extremely limited debt servicing capacity for 2009-11 and unsustainable public debt levels, a comprehensive official and private debt restructuring is needed to close financing gaps and put medium-term debt on a sustainable path (Section C and DSA supplement).

- $\quad$ Downside risks to the outlook have risen. The main upside risks would come from faster declines in world food and fuel prices, which would contribute to lower projected inflation and reduce the current account deficit. However, uncertainty about the monetary transmission mechanism and weak instruments could hamper CBS' control of inflation. Furthermore, a global slowdown will dampen growth and widen the current account deficit through lower tourism receipts and FDI growth. FDI projections are based on conservative assumptions about implementation of the existing pipeline of projects, mostly hotels. Tight credit conditions in advanced and emerging economies may affect FDI financing and delay implementation. However, due to the high import content of FDI ( 85 percent) and assumptions about profit repatriation, FDI's balance of payments impact is modest. 
Text Table 1. Seychelles: Main Macroeconomic Assumptions and Targets, 2007-2013

\begin{tabular}{|c|c|c|c|c|c|c|c|}
\hline & $\begin{array}{r}2007 \\
\text { Est. }\end{array}$ & $\begin{array}{c}2008 \\
\text { Proj. }\end{array}$ & $\begin{array}{l}2009 \\
\text { Proj. }\end{array}$ & $\begin{array}{l}2010 \\
\text { Proj. }\end{array}$ & $\begin{array}{l}2011 \\
\text { Proj. }\end{array}$ & $\begin{array}{l}2012 \\
\text { Proj. }\end{array}$ & $\begin{array}{l}2013 \\
\text { Proj. }\end{array}$ \\
\hline & \multicolumn{7}{|c|}{ (Annual percentage change, unless otherwise indicated) } \\
\hline Real GDP & 7.3 & 3.1 & -0.5 & 3.5 & 5.0 & 5.0 & 5.0 \\
\hline CPI (Annual average) & 5.7 & 32.2 & 33.8 & 12.6 & 5.8 & 3.2 & 3.0 \\
\hline \multirow[t]{2}{*}{ CPI (End-of-period) } & 16.8 & 38.8 & 21.6 & 11.5 & 3.0 & 3.0 & 3.0 \\
\hline & \multicolumn{7}{|c|}{ (Percent of GDP) } \\
\hline Overall fiscal balance, including grants (above the line) & -9.8 & -1.8 & -6.1 & -1.1 & 0.9 & 3.5 & 3.0 \\
\hline Primary fiscal balance $1 /$ & -2.3 & 7.1 & 6.2 & 6.6 & 6.8 & 5.8 & 5.5 \\
\hline Total public debt $2 /$ & 146.0 & 151.3 & 161.3 & 149.5 & 138.4 & 126.6 & 121.0 \\
\hline Domestic & 74.1 & 53.5 & 41.5 & 34.3 & 26.7 & 20.0 & 20.0 \\
\hline External & 71.9 & 97.8 & 119.8 & 115.2 & 111.7 & 106.6 & 101.0 \\
\hline Current account balance after official transfers & -23.4 & -28.8 & -20.9 & -21.4 & -21.7 & -20.2 & -20.6 \\
\hline Total stock of arrears (millions of U.S. dollars) & 160.4 & 330.6 & $\ldots$ & $\ldots$ & $\ldots$ & $\ldots$ & $\ldots$ \\
\hline Gross official reserves (weeks of imports) & 0.1 & 0.2 & 0.8 & 9.2 & 12.1 & 14.1 & 15.9 \\
\hline
\end{tabular}

\section{Exchange Regime Reform and Exchange Rate Policy}

\section{Staff and the authorities agreed that a fundamental liberalization of the} exchange regime and the rate-determination mechanism are critical to restore credibility in the rupee and eliminate the parallel market (MEFP -14-15). Staff's analysis suggests that, as of mid-2008, the exchange rate remained significantly overvalued, notwithstanding the 2006-07 step devaluations (Box 1 and Figure 3). Indications are that the parallel exchange rate has remained fairly stable at a premium above the official rate (about 55 percent lately), but dollarization has been rising rapidly in recent years (Figure 2). Staff is of the view that given the lack of credibility in the peg, the near-exhaustion of external reserves, a significant parallel market, a managed float of the rupee was the only alternative, at least in the short-term. This does not prejudge what the appropriate long-run exchange rate regime for Seychelles would be. Various options, including full dollarization or euroization, or a currency board, have their merits for a small open economy such as Seychelles and will be carefully assessed once the economy has stabilized. A large step devaluation did not appear feasible given the difficulty of assessing the magnitude of adjustment needed and the CBS'very limited ability to defend the new rate. 
Figure 2. Seychelles: Official versus Parallel Exchange Rate Developments, Jan. - Sept., 2008 (Seychelles rupee versus official U.S. dollar and Euro, and parallel U.S. dollar)

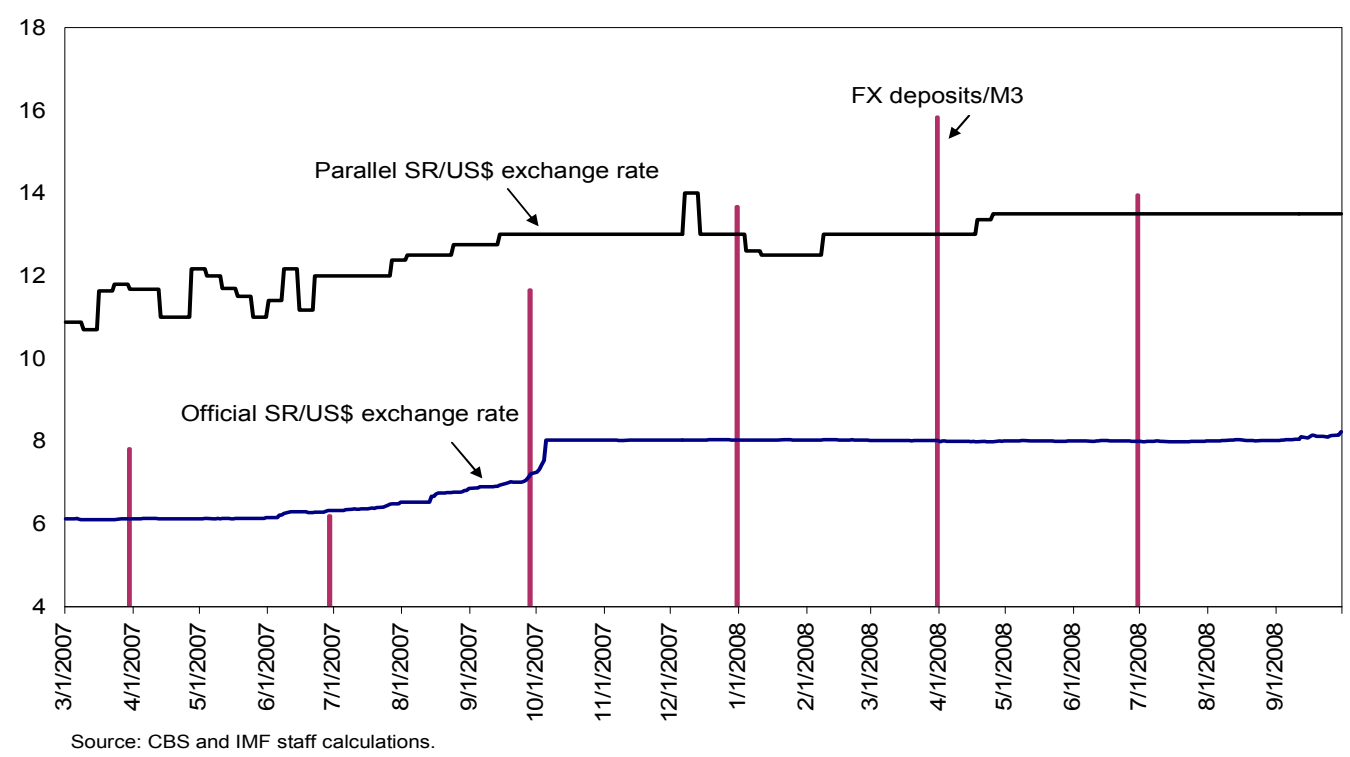

12. The authorities indicated a strong determination to removing all exchange restrictions subject to Fund jurisdiction under Article VIII and other exchange measures, in a clear break with past policies. In particular, requirements to surrender foreign exchange earnings and to pay for certain transactions and taxes in foreign exchange were repealed on October 31, effective November 3. With the elimination of these measures, the exchange system is free of restrictions on both current and capital transactions.

Remaining restrictions subject to Fund jurisdiction under Article VIII have disappeared.

\section{The authorities are committed to limit their interventions in the foreign} exchange market to smoothing excessive volatility, preserving orderly market conditions and supporting the reserve accumulation objective. With technical assistance from the Fund, the authorities have established a platform at the CBS for interbank foreign exchange trading. Initially, trading will be supported by a manual book-entry system, with the view to moving to a real-time gross settlement system over the coming year. In parallel, supervision of commercial banks' risk management and FX trading practices will be strengthened, to ensure that they promptly establish internal rules based on international best practices. To stimulate competition in the foreign exchange market new foreign exchange bureaus will be licensed.

\section{The authorities are aware of the risks associated with a large exchange rate} depreciation and are ready to take necessary supporting measures. Maintaining an appropriately tight monetary and, particularly, fiscal policies will be key to anchor the move to a floating regime. A remaining overhang of unrepatriated profits and dividends by foreign firms, subsequent to the late-2007 clearing, may put pressure on the exchange rate initially. Given the initial low level of official reserves, vulnerabilities to further unfavorable external developments would remain high for some time. 


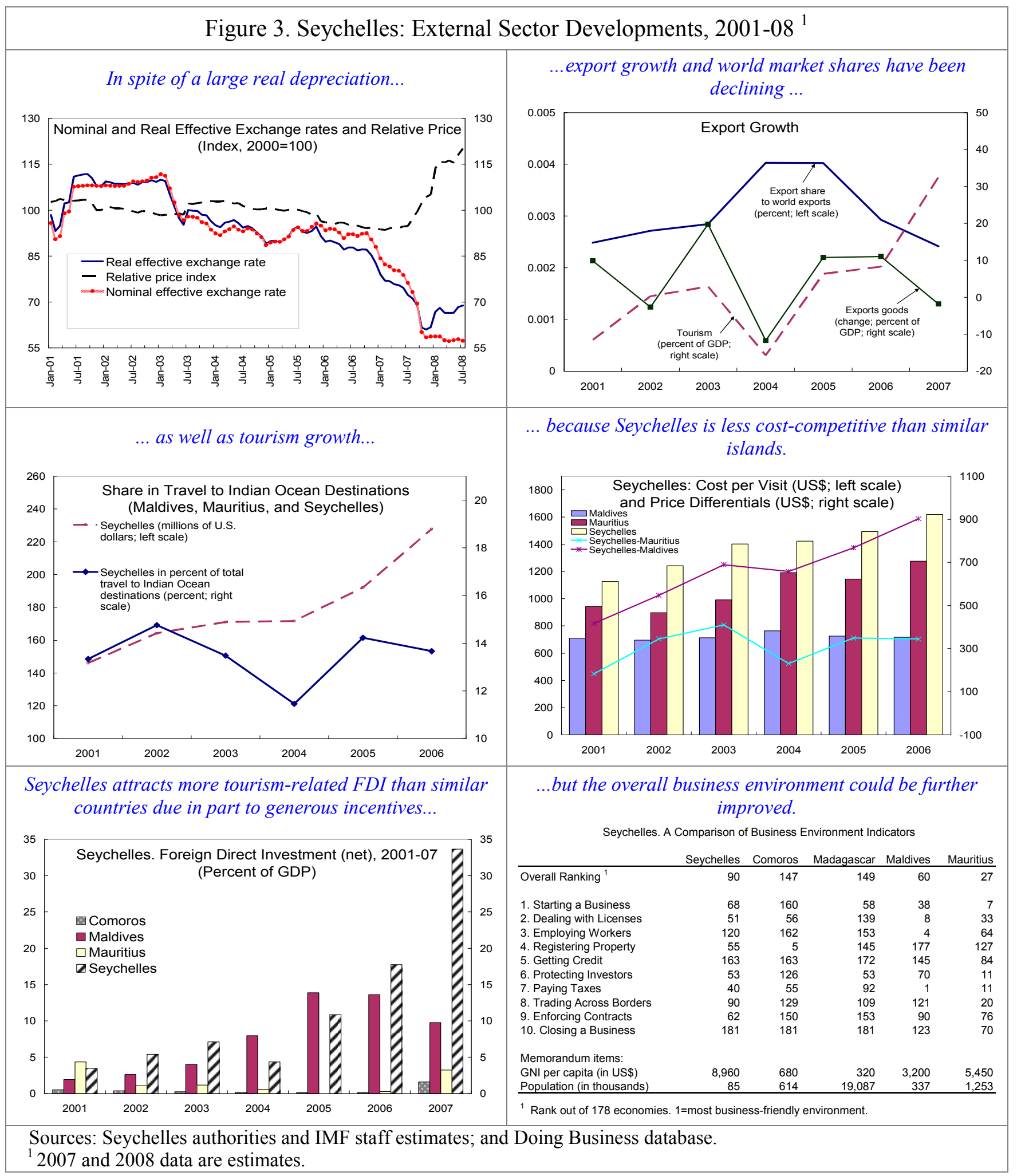




\section{Box 1. Seychelles: External Stability and Exchange Rate Assessment}

In spite of some competitiveness gains stemming from the 2006-07 step devaluations of the fixed exchange rate, most indicators continue to point to a significant overvaluation of the real effective exchange rate (REER) in mid-2008. By end-June 2008, the REER had depreciated by about 38 percent since its peak in Januar 2003. However, the current account deficit widened markedly from 2007, external arrears have grown rapidly, and the parallel market premium remains high at about 55 percent. A more formal exchange rate assessment based on a variety of approaches, indicates the following.

\section{Equilibrium real exchange rate} (ERER) estimation based on past values of fundamentals points to an overvaluation of about 11-26 percent. ERER estimation for a panel of 28 subSaharan African (SSA) countries finds the REER for Seychelles to be about 26 percent overvalued. Using a smaller panel of small Indian Ocean islands

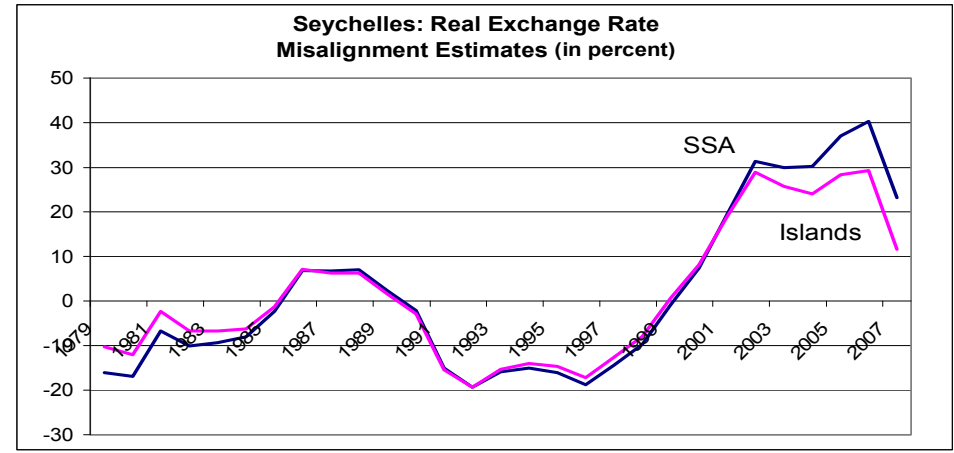

Sources: INS, IFS; IMF staff calculations.

Notes: SSA line indicates estimated REER misalignment based on estimation of the ERER for a panel of 28 sub-Saharan African countries, using Pesaran et al (1999) pooled mean group estimator-Variables used in the estimation include openness, terms of trade, and government consumption and GDP per capita, both relative to trading partners.

Island line indicates estimated misalignment based on a panel of 4 Indian Ocean islands (Comoros, Madagascar, Mauritius and Seychelles), using the same set of fundamentals and Pedroni's (2000) fully modified OLS estimator.

(Islands) and a different estimator, the overvaluation is found to be about 11 percent. Panel estimation mitigates some of the problems of single-equation methods, including poor REER and CPI data in Seychelles and the short sample period.

The external sustainability approach suggests a commensurate overvaluation of 12-33 percent for plausible ranges of the benchmark net foreign asset position (NFAP). As indicated by the DSA, the external debt position (and underlying current account path) is clearly unsustainable, so that a comprehensive debt restructuring would be needed. Therefore the benchmark NFAP is calculated based on long-run values of each NFAP component consistent with debt sustainability. The calculations illustrate the change in the exchange rate that would be needed to bring about the necessary adjustment in the underlying current account. A plausible range for the benchmark NFAP is assumed to be -200 to -100 percent of GDP, depending on whether one assumes that the private sector's net foreign position would remain positive, or that it would decline as improved confidence Seychelles: Sustainable Long-Run NFA Position (in percent of GDP; unless otherwise indicated)

\begin{tabular}{lrr}
\hline & 45.6 & 45.6 \\
Central bank net foreign assets 1/ & 8.8 & 8.8 \\
Commercial banks net foreign assets 2/ & -40.0 & -40.0 \\
Public external debt 3/ & -200.0 & -200.0 \\
Net FDI stock 2/ & 0.0 & 0.0 \\
Net portfolio investments & 159.4 & 79.7 \\
Net external position of non-bank private sector & -26.2 & -105.9 \\
Total & & \\
Source: IMF staff calculations. & \\
Notes: 1/ Corresponds to 3 months of imports. \\
2/ Consistent with medium-term balance of payments. \\
3/ Based on the authorities' target of a total public debt of 60 \% of GDP, \\
leaves 20\% of GDP for domestic debt.
\end{tabular}

Seychelles: External Sustainability Approach 1/ (in percent of GDP; unless otherwise indicated)

\begin{tabular}{|c|c|c|c|c|}
\hline \multirow{3}{*}{$\begin{array}{c}\text { Benchmark } \\
\text { NFAP }\end{array}$} & \multicolumn{3}{|c|}{ Current account } & \multirow{3}{*}{$\begin{array}{c}\text { Misalignment } \\
\text { in percent } 4 /\end{array}$} \\
\hline & that stabilizes & Underlying CA & Deviation $3 /$ & \\
\hline & NFAP & $20082 /$ & & \\
\hline \multicolumn{5}{|c|}{ Based on an estimated current account elasticity of -0.4} \\
\hline-25 & -1.9 & -21.2 & -19.3 & 46.7 \\
\hline-100 & -7.5 & -21.2 & -13.7 & 33.0 \\
\hline-200 & -15.1 & -21.2 & -6.1 & 14.9 \\
\hline \multicolumn{5}{|c|}{ Sensitivity analysis for current account elasticity of -0.5 . } \\
\hline-25 & -1.9 & -21.2 & -19.3 & 38.6 \\
\hline-100 & -7.5 & -21.2 & -13.7 & 27.3 \\
\hline-200 & -15.1 & -21.2 & -6.1 & 12.3 \\
\hline
\end{tabular}

Source: IMF staff calculations and projections.

$1 /$ Based on an estimated current account elasticity of -0.4 .

2/ Underlying current account is actual current account corrected for the peak in food and fuel prices.

3/ Underlying current account less NFAP-stabilizing current account.

4/ Implied overvaluation ("+") of the real effective exchange rate. include offshore transactions which, at 159 percent of GDP in March 2008, overstate the private sector's NFAP). The 2008 underlying current account deficit (21.1 percent of GDP) excludes the net impact of the peak in food and fuel prices.

Competitiveness indicators paint a more mixed picture but overall indicate that a combination of exchange rate adjustment and structural improvement in the business environment would be needed (see Figure 3 ). 


\section{Restoring Public Debt Sustainability}

\section{Fiscal Policy}

\section{A sustained fiscal tightening is critical to anchor a floating exchange rate and to} place public debt on a sustainable path. After a large adjustment in 2008, primary surpluses of 6.5 percent of GDP on average are programmed in 2009-11. ${ }^{1}$ The authorities' fiscal strategy rests on a combination of expenditure restraint, revenue enhancement, strengthened public financial management, and public sector reform, including further privatization of public enterprises (MEFP 118). The World Bank is conducting a Public Expenditure Review with the objective of helping the authorities raise the efficiency of health and education spending, as well as prepare an agenda for civil service, social security, and public enterprise reforms. Staff welcomed the revenue and expenditure measures already implemented in October and November 2008, which, together with those to be introduced with the 2009 budget, reflect the authorities' strong

\begin{tabular}{|lcc|}
\hline \multicolumn{2}{|c|}{ Text Table 2. Seychelles: Budgetary Impact of Fiscal Measures } & \\
\hline Fiscal Measures & \multicolumn{2}{c|}{ Impact $^{1}$} \\
& $\mathbf{2 0 0 8}$ & $\mathbf{2 0 0 9}$ \\
\hline Revenue Measures & $\mathbf{0 . 4}$ & $\mathbf{3 . 1}$ \\
Eliminate tax exemptions & 0.0 & 0.6 \\
Raise taxes & 0.3 & 1.6 \\
Adjust fees, fines, charges and rents and royalties for inflation & 0.0 & 0.5 \\
New taxes & 0.1 & 0.4 \\
Expenditure Measures & $-\mathbf{0 . 1}$ & $\mathbf{2 . 0}$ \\
Eliminate subsidies & 0.1 & 1.5 \\
Introduce a targeted social safety net by enacting Agency on Welfare Act & -0.2 & -1.0 \\
Reduction in the public sector wage bill & 0.0 & 1.5 \\
Net Budgetary Impact & $\mathbf{0 . 3}$ & $\mathbf{5 . 0}$ \\
\hline Sources: Ministry of Finance and IMF staff calculations. & & \\
' In percent of GDP. & & \\
\hline
\end{tabular}
commitment to tighten the fiscal stance (Text Table 2).

16. The 2009 budget will aim at a primary surplus achieved through savings on transfers and subsidies, a decline in the wage bill, and a rise in tax revenues. The impact of the exchange rate depreciation is expected to be only moderately positive on the budget given the high share of imports in spending. Fiscal adjustment is somewhat back loaded in 2009 owing to the frontloading of the contingency for potential recapitalization needs for the public financial institutions, the seasonality of revenue collections, and staffing redundancy payments in the first quarter. ${ }^{2}$ Expenditure measures focus on:

- $\quad$ The replacement of indirect product subsidies by a targeted, modernized social safety net is an essential part of the authorities' strategy to mitigate the negative social

\footnotetext{
${ }^{1}$ This fiscal path is in line with the experience of large fiscal adjustments in small states where the fiscal effort is often frontloaded and sustained for a number of years, see Chapter I of Seychelles: Selected Issues (www.imf.org).

${ }^{2}$ The program includes an adjustor raising the primary balance target for any contingency amounts not used for that purpose.
} 
impact of the policy reforms, and should produce net budgetary savings in 2009 (MEFP q20).

- Implementation of a voluntary and involuntary departure scheme is expected to reduce the number of public sector employees by 12.5 percent by end 2008 . Together with moderate wage increases, this should lead to a significant reduction of the wage bill (MEFP q23).

17. On the revenue side, staff welcomed the authorities' strategy of moving toward a simplified and harmonized tax system, while strengthening revenue administration. As a first step, some tax exemptions have been removed, and discretionary powers to grant exemptions have been eliminated. In spite of adjustments for inflation (MEFP 919), overall non-tax revenue is projected to decline in 2009 and 2010 because of lower dividend payments from public enterprises and a decline in the statutory transfer from the central bank. ${ }^{3}$ Importantly, the authorities are committed to a fundamental review of the tax regime with IMF technical assistance.

\section{Toward A Comprehensive Debt Restructuring Strategy}

18. The authorities, assisted by financial and legal advisors, are elaborating a comprehensive debt restructuring strategy to put public debt back on a sustainable path.

- The fiscal effort envisaged under the program aims at a significant reduction in the stock of domestic debt, the value of which is being eroded by negative real interest rates in 2008, especially on the long-term maturities with fixed coupons. Given the domestic banks' exposure to government securities (almost 45 percent of assets) and vulnerability to higher default risk under the program, staff and the authorities agreed that banks would not be in a position to take a further significant haircut on government securities.

- $\quad$ Public debt is projected to remain unsustainable over the medium-term in the absence of debt restructuring, even assuming full implementation of all program reforms (Table 9 and Supplement 1). Seychelles' debt is among the highest in the world and far higher than in other small states (Figure 4). The restructuring strategy is predicated on securing significant cash flow relief in the short to medium-term and a debt burden consistent with long-term payments capacity. The authorities have already engaged in preliminary consultations with Paris Club creditors, who have indicated a willingness to consider Seychelles' debt under the Evian approach. Debt reconciliation efforts are under way, and debt stock data may well be revised. A census of commercial debt holders has been launched, but the wide dispersion of

\footnotetext{
${ }^{3}$ Unrealized valuation gains from foreign currency fluctuations will not longer be transferred from the CBS to the government.
} 
holdings and the current financial market turmoil may lengthen the identification process and negotiations with commercial creditors. Discussions with commercial and other official creditors are planned to begin in November 2008.

Figure 4. Selected Small-State Indicators, 2002-2008
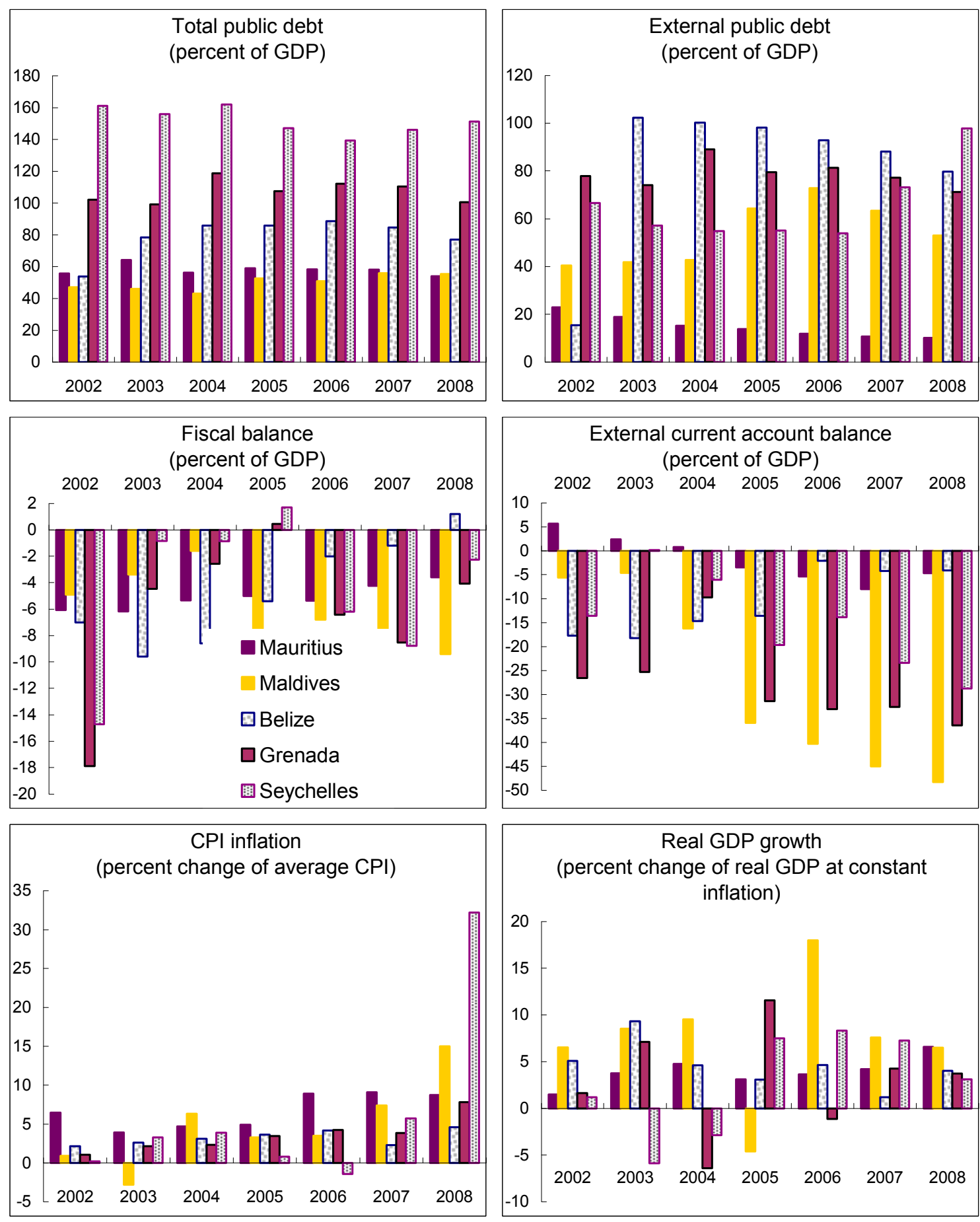

Source: WEO, October 2008; and IMF staff calculations. 
19. The staff's preliminary debt sustainability analysis (DSA, Supplement 1) clearly shows that public debt is unsustainable. Under a baseline scenario assuming new borrowing on commercial terms to refinance arrears and close financing gaps, external debt reaches 165 percent of GDP by 2018. Bounds tests clearly show that it is also highly vulnerable to all standard shocks.

20. Given the magnitude of Seychelles' debt burden, a comprehensive debt restructuring involving a substantial reduction in the debt service burden consistent with Seychelles' long-term ability to pay will be needed to restore debt sustainability. Moreover, staff's preliminary analysis suggests that even with a sharp present value reduction of the public debt burden, Seychelles is likely to remain highly vulnerable to a wide variety of shocks for an extended period of time. Staff believes that there are reasonable expectations that a restructuring of the public debt consistent with Seychelles' payments capacity is possible. Staff expects to present a more comprehensive sustainability analysis on the basis of an updated medium-term outlook, at the time of the first program and financing review.

21. The authorities are committed to strengthening public debt management (MEFP q17). A new Public Debt Law will define a legal framework for debt management and operations will be strengthened with IMF technical assistance. Debt and recording systems need to be enhanced, together with the public financial management framework, to ensure that no new external or domestic arrears are accumulated. The Public Debt Management Committee will closely monitor parastatal borrowing. Priority areas for technical assistance include communication and coordination between various bodies responsible for public debt, reporting and auditing, improving operational risk procedures (data records and audits, operational manuals), and managing contingent liabilities (such as guarantees on parastatal debt).

\section{E. Reforming Monetary Policy and Maintaining Financial Sector Stability}

\section{Monetary Policy Framework}

22. The CBS attaches priority to reforming monetary policy, a key element to securing price stability and supporting a successful move to a floating regime. The ability of the central bank to contain monetary expansion has been limited to date, reflecting the pegged exchange rate regime, fiscal dominance and-until recently-the absence of indirect instruments of monetary control. In preparing for the float of the rupee, the authorities have established weekly auctions for short-term commercial bank deposits at the CBS and for 91-day Treasury bills. Banks are actively participating in the market and the beginnings of a yield curve are emerging (Text Table 3). Higher market-determined interest rates will be crucial to limit the extent of exchange rate overshooting, following the move to a floating regime. As part of the reform, the CBS is committed to regularly communicate policy changes and implementation to the market (MEFP $\mid 27-28$ ) 
Text Table 3. Seychelles: Auction Results, September-October 2008

Treasury Bills (weekly auction results; average tender rate in percent)

Maturity period

91 days

\begin{tabular}{rrrrr|}
\hline $23-$ Sep & 3 -Oct & $10-$ Oct & 17 -Oct & $24-$ Oct \\
\hline 5.9 & 8.7 & 10.2 & 10.2 & 10.5
\end{tabular}

Deposit Auction Arrangement (weighted average DAA rate in percent)

Maturity periods

7 days

14 days

28 days

$22-S e p$
5.3
5.1

$\begin{array}{rr}2 \text {-Sep } & 1-\mathrm{O} \\ 5.3 & 5 \\ 5.1 & 6 \\ 5.3 & 7.7\end{array}$

5.3

Oct
5.7
6.8
7.7

7.7

8-Oct

7.1

7.8

15-Oct

22-Oct

Source: Central Bank of Seychelles.

23. The monetary program is based on a quarterly reserve money target. Staff considers that a monetary aggregate target is the most viable nominal anchor for Seychelles (as compared to an interest rate or inflation target) due to the low level of financial market development and very recent liberalization of interest rates. However, the stability of the money multipliers is likely to be affected by the exchange regime switch, as indicated by the 2006-07 devaluation episode (Figure 5) and staff will closely monitor developments.

Figure 5. Seychelles: Money Multipliers, December 2001 - June 2008

(Quarterly data)

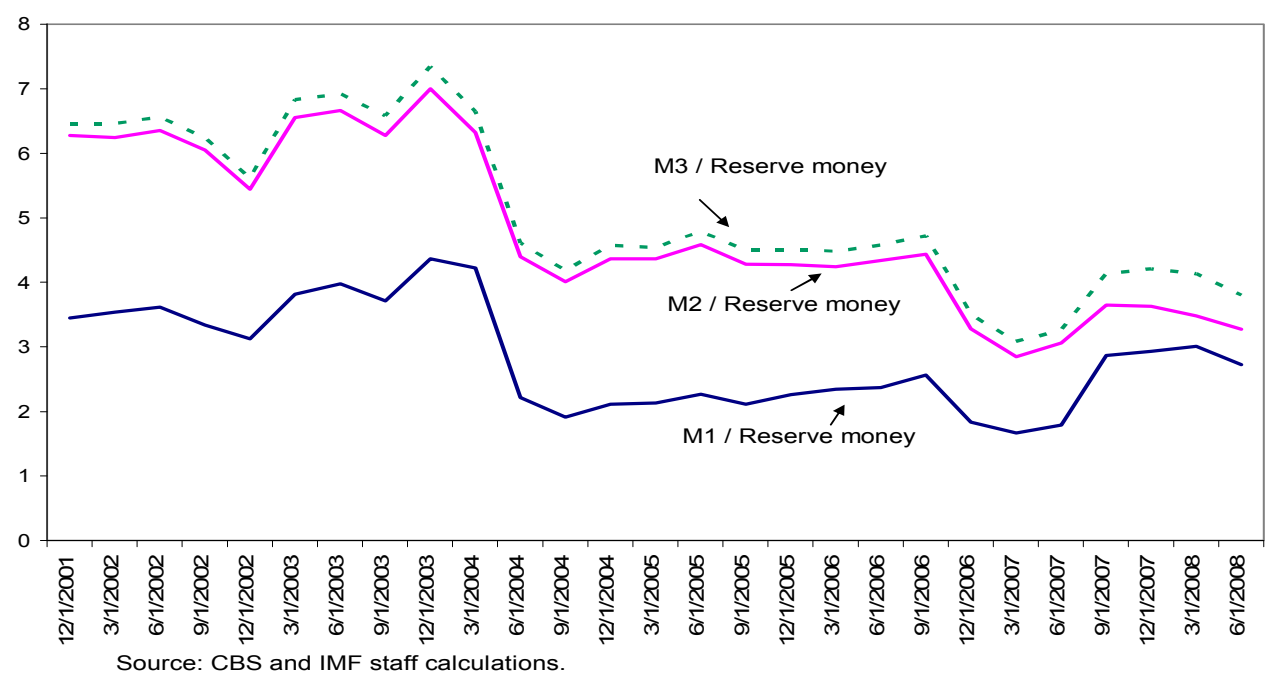

24. The program envisages that the velocity of circulation will rise initially as will the money multiplier, implying the need to maintain very tight reign on reserves money in the period around the float of the currency. As confidence in the new regime, with the support of tight fiscal policy and likely much higher market-based interest rates, there will be room for some recovery in liquidity growth and credit to the economy. A key challenge to the conduct of monetary policy, particularly at the onset of the float, will be uncertainty about the monetary transmission mechanism, and a considerable amount of "learning by doing" will be needed. In particular, close cooperation between Treasury and the CBS is essential for improving liquidity management. 


\section{Staff agreed with the authorities that the continuation of the substantial IMF} technical assistance to the CBS would be necessary to support the reform effort. In particular, staff strongly supports the authorities' request for a long-term monetary advisor to help them deal with the transition from a fixed to floating exchange rate regime. Fund technical assistance will also be necessary to support other key reform areas, including establishing and automating the interbank market for securities, bank deposits and foreign exchange; introducing a reserve money monetary framework; strengthening bank supervision; and reinforcing CBS governance and transparency in light of the recommendations from the September 2008 safeguards assessment mission.

26. The authorities are committed to addressing the high risk areas identified by the recent safeguards assessment mission. The authorities have recently issued a tender for new external auditors to begin with the 2008 accounts in compliance with international audit standards. The Ministry of Finance and CBS will sign by end-December 2008 a memorandum of understanding strengthening and formalizing the terms and conditions under which the CBS transacts on behalf of government. A revision of the CBS act to strengthen governance and accountability will be implemented with Fund technical assistance and is a condition for completion of the first program review (MEFP \30).

\section{Financial Sector Stability}

\section{The large changes to monetary and exchange policies pose a significant} adjustment challenge in the short term for the financial system. Staff discussed various measures that the authorities could implement to mitigate the risk for the stability of the financial system during the transition. Based on financial analysis and stress testing, the major risk confronting banks comes from expected increases in default rates on bank loans (Figure 6 and Box 2). Banks are well positioned for first round effects of changes in interest rates (as their loans are effectively variable rate) and exchange rate depreciation (due to their large net open positions). Both of these changes, however, will impact some borrowers' ability to service their loans and lead to higher default rates. Estimating the impact of both FX depreciation and heightened interest rates is problematic. One way to judge the risk, however, is to calculate the coverage bank capital after first round effects can withstand second round effects. After adjusting bank capital for credit risk, the possible consequences of higher interest rates and the exchange rate leave banks with capital coverage of 27 to 34 percent of their loan portfolio. Distribution of this risk is fairly even. Banks also have some interest rate risk from their holdings of government bonds, although one third of these are due to mature within one year.

\section{The program includes contingencies to cushion for the impact of increased} default risk on bank capitalization. In addition to CBS liquidity support, the 2009 budget includes a specific contingency for the potential recapitalization needs of government-owned financial institutions. It is important to note that the CBS does not have experience handling bank failure and MCM TA on supervisory intervention and failed bank resolution has not yet been delivered. 


\section{Global financial turbulence may also directly affect the five foreign-owned banks} in Seychelles, through the impact on their parents. Staff encouraged the CBS to closely coordinate analysis of potential recapitalization costs with the Ministry of Finance.

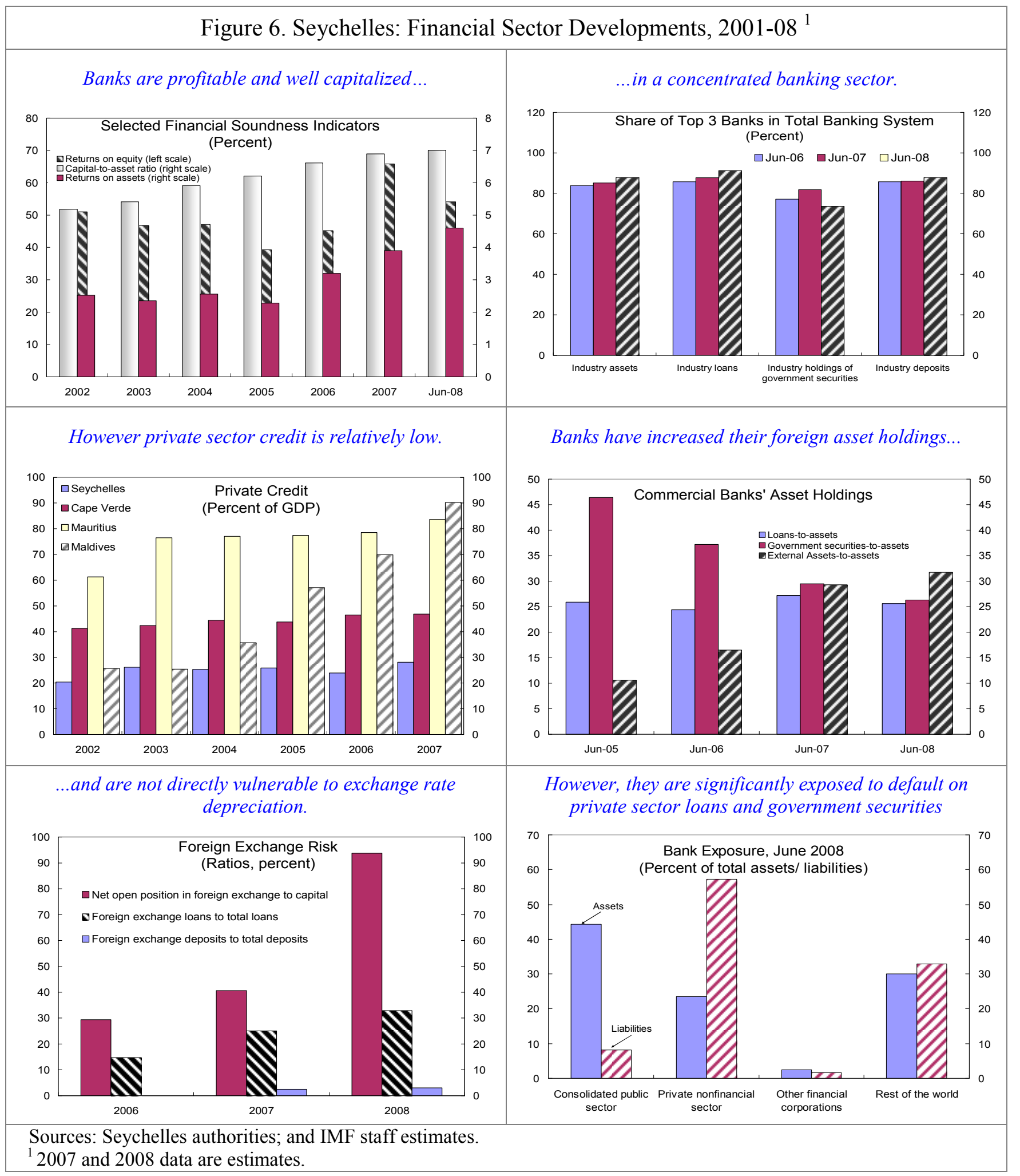




\section{Box 2. Seychelles: Financial Sector Vulnerabilities and Stress-Testing Results}

Stress testing of interest rate increases and rupee depreciation reveals that, while banks are presently sound, their capitalization may be significantly strained.

First round effects stemming from a depreciation are expected to be positive. Because banks have long net open positions in foreign currencies, ceteris paribus, a depreciation of the exchange rate against those currencies improves net capitalization.

\begin{tabular}{|l|l|l|l|l|}
\hline \multicolumn{5}{|c|}{$\begin{array}{l}\text { Illustrative Scenarios: Impact of Exchange Rate Devaluation on Banking System } \\
\text { Capitalization (in percent, as of end-June, 2008) }\end{array}$} \\
\hline & $\begin{array}{l}\text { Current Net } \\
\text { Capitalization }\end{array}$ & $\begin{array}{l}\text { New Net } \\
\text { Capitalization } \\
\text { with stronger bad } \\
\text { loan provisioning }\end{array}$ & $\begin{array}{l}\text { New Net } \\
\text { Capitalization } \\
\text { After Direct FX } \\
\text { Shock }\end{array}$ & $\begin{array}{l}\text { Capital } \\
\text { Coverage of } \\
\text { Net Loans } \\
\text { (2nd round } \\
\text { effects) }\end{array}$ \\
\hline $\begin{array}{l}50 \text { percent } \\
\text { devaluation }\end{array}$ & 5.6 & 5.4 & 6.6 & 26.5 \\
\hline $\begin{array}{l}125 \text { percent } \\
\text { devaluation }\end{array}$ & 5.6 & 5.4 & 8.3 & 33.9 \\
\hline
\end{tabular}

Higher interest rates could have negative first and second round effects.

As banks in Seychelles have the capacity to re-price domestic loans as fast as their liabilities, it is assumed banks can maintain their net interest margins and largely be unaffected from the first round direct effects of changes in interest rates. The banks cannot re-price all of their domestic investments, however. For example, treasury bonds have fixed coupons and the stateowned savings bank has some term loans whose rates are fixed. Stress tests show that one bank would become under-capitalized if treasury bonds were marked-to-market (though not required in Seychelles). Nevertheless, five of the banks would suffer income losses during a high interest rate period until their bonds mature (28 percent of the banks' aggregate bond portfolio was to mature within one year as of June 30, 2008).

An additional risk comes from second round effects. Banks would achieve maintenance of their interest margins by increasing interest rates on their customers' loans, and default rates on those loans should be expected to increase. As the relationship between default rates and higher interest rates cannot be forecast accurately with available data, the tolerance of bank capital to loan losses is calculated.

Altogether, with a 50 percent depreciation, bank industry capital (unadjusted for interest rate first round shocks) can absorb a 27 percent loss to their loan portfolio before industry capital were to be exhausted-34 percent with a 125 percent depreciation.

Some government-owned financial institutions would be vulnerable to foreign exchange risks and to second-round effects of higher interest rates on loan defaults. If loan losses grow to 20 percent of June 2008 loan balances, only one institution is projected to require recapitalization, with the fiscal cost amounting to about SR 82 million (1 percent of GDP). If loan losses rose to 40 percent, all four government-owned institutions would require recapitalization or resolution, and the total cost could reach about SR 333 million (4 percent of GDP). 


\section{F. Structural Reforms}

30. Structural reforms under the SBA-supported program would focus on key areas to support macroeconomic stabilization. The authorities are also committed to working with staff and other development partners to develop a more comprehensive structural reform program that would be implemented over the medium term. Once this work is finalized, the authorities intend to request a longer-term engagement with the Fund under the Extended Fund Facility.

\section{Enhancing Fiscal Governance and Transparency}

31. Strengthening the public financial management system is a key priority of the authorities, and is essential to support and facilitate the fiscal consolidation. The authorities are committed to implementing the key recommendations of a recent review of public financial management by an IMF technical assistance mission (MEFP q22), including by strengthening budget preparation, execution, accounting and reporting. Key measures include:

- $\quad$ Preparing a medium-term macroeconomic framework aimed at achieving fiscal sustainability to help frame annual budgets;

- Including the social security fund and the pension fund in all fiscal analysis and in presentations, and integrating the current and capital budget process;

- $\quad$ Setting detailed expenditure ceilings for each ministry and authority and distinguishing between base-line and new expenditures in budget submissions;

- $\quad$ Establishing a cash management system and a single treasury account; and

- $\quad$ Strengthening financial management, reporting and auditing in line ministries.

32. A fundamental review of tax policy and revenue administration is needed to eliminate distortions to economic activity and discourage evasion. The current system, characterized by differentiated and high overall business tax rates, with significant exemptions, should be harmonized and the base broadened to enhance fairness and improve compliance. The authorities have requested IMF technical assistance to conduct a comprehensive diagnostic tax policy and revenue administration review. The review is also expected to assist with strengthening tax auditing capacity (MEFP $\mid 24-25$ ).

33. The authorities are committed to providing a clear, rules-based and transparent regulatory framework for domestic and foreign investment, and to improving governance and accountability. 
- $\quad$ The authorities are revamping the framework for FDI to provide a more transparent and level playing field to new investors. ${ }^{4}$ The approval of new projects will require Ministry of Finance vetting and the ability of line ministries to grant tax incentives will be removed. As a first step, provisions for the granting of new discretionary exemptions in the trade and business tax acts have been repealed (MEFP q32).

- $\quad$ The authorities are in the process of strengthening the legal framework to enhance governance and accountability. A Public Officers Ethics Act was adopted in August 2008, which requires full financial disclosure by November 2008 and prohibits conflicts of interest. A Public Procurement Act will be passed by December 2008, which will enhance the transparency of bidding procedures (MEFP 933 ).

\section{Reducing the Role of the State in the Economy}

34. The authorities are committed to gradually reduce the size of the public sector, through civil service reform and further privatization. The public sector in Seychelles is large even by small-state standards (about 40 percent of total employment), and government involvement in economic activity is crowding out the private sector. With the World Bank's assistance, the government's public service reform aims at avoiding duplication of functions, outsourcing to the private sector, and reducing public employment. As of end-2007, public enterprises represented a net drain on the budget of 2.8 percent of GDP, and government guarantees on parastatal loans amounted to 5.2 percent of GDP as of mid-2008. The authorities highlighted their commitment to privatizing a number of public enterprises in 2009 in the trade sector and to avoid retaining minority stakes in these enterprises (MEFP q26).

\section{DATA Issues}

\section{Though Seychelles statistics are generally adequate for surveillance, key} macroeconomic statistics need to be improved. In particular, weaknesses in deflator estimates and foreign trade statistics limit their usefulness for surveillance, economic analysis, and policy formulation. The country participates in the GDDS and is one of two pilot countries in AFR for the GFSM 2001 framework for compiling fiscal data. The authorities are reviewing national accounts data, and are have recently revised up nominal GDP by some 20 percent, mainly due to improved coverage. The authorities are strongly encouraged to continue their efforts to improve national statistics and will request technical assistance from the Fund.

\footnotetext{
${ }^{4}$ See Chapter II of Seychelles: Selected Issues (www.imf.org).
} 


\section{Program Design, Financing ANd Risks}

\section{A. Program Design and Monitoring}

36. Quarterly quantitative performance criteria would be set on net international reserves (NIR), reserve money, and the fiscal primary balance (MEFP Table 1). There would be a symmetric adjustor on NIR for deviations from projected program financing, and the usual interdiction on the accumulation of external and domestic arrears. The program would include a non-zero limit on external borrowing from official creditors for program financing purposes, and zero sub-ceilings on short-term external borrowing and commercial external borrowing, respectively.

37. Access under the two-year SBA is proposed at SDR 17.6 million (200 percent of quota), with 70 percent of quota disbursed upon approval of the arrangement (Table 9). This frontloading of access is a reflection of the front-loaded nature of the reform program and is in consideration of the low level of official reserves as the authorities launch the fundamental liberalization of the exchange regime and float the currency.

38. Structural conditionality focuses on macro-critical measures to strengthen fiscal and CBS governance (MEFP Table 2). Important measures have already been implemented. These include the upfront fiscal adjustment and fiscal reforms to eliminate subsidies and reduce exemptions, the liberalization of the exchange regime, and the reform of the monetary policy framework. The structural performance criterion reflects the authorities' commitment to bolstering tax administration on the fiscal adjustment effort, and they have already announced the measure in the press. The program includes initial steps to address important weaknesses at the CBS identified by the safeguards assessment conducted in September 2008. The program also includes a requirement for the CBS's new external auditor to confirm NIR and reserve money data at each program test date. The first program review will focus on key areas for program success including a full work plan to address all safeguards areas (MEFP, ๆ 38).

\section{B. Program Financing}

39. Timely financial support from multilateral and official creditors is critical for the success of the program as residual financing gaps are significant. The program is fully financed for 2008. For 2009, the external nonproject financing requirement is expected to be closed by disbursements from the Fund under the prospective SBA (30 percent of quota; SDR 2.64 million), from other multilateral creditors such as the World Bank and the AfDB (US\$15 million), and from public debt relief (US\$85 million) (Table 10). Financing assurances reviews will be completed at the time of program reviews (MEFP 937 ).

40. The proposed program is consistent with the Fund's arrears policy. Staff have approached the Paris Club creditors seeking financing assurances aimed at addressing both liquidity and sustainability issues of Seychelles' debt under the Evian approach. The authorities have engaged in discussions with multilateral creditors and plan to clear arrears to 
those creditors during the program period. The authorities are committed to engaging in collaborative discussions with private creditors with a view to reaching agreement through an open and transparent dialogue based on the principle of inter-creditor equity. Staff believes that there are reasonable expectations that a restructuring of the public debt consistent with Seychelles' payments capacity is possible. A census of external commercial creditors has been launched but the wide dispersion of individual holdings and recent financial market turmoil may lengthen the identification process and negotiations with commercial creditors. Staff understands that contacts with commercial creditors are planned in November 2008 (MEFP \16).

\section{Indicators of Fund credit suggest Seychelles should not have difficulty meeting} its obligations to the Fund under the proposed arrangement. Seychelles has no outstanding liabilities to the Fund. Under the proposed two year SBA in an amount of 200 percent of quota, outstanding Fund credit would peak in 2010 at 2.5 percent of exports, or about 18 percent of projected official reserves (Table 11). Prospective obligations to the Fund would peak in 2013 at a moderate 0.8 percent of exports or 3.3 percent of projected reserves. However, a more difficult global economic and financial environment, as well as a more protracted negotiation process with commercial creditors are major risks to Seychelles capacity to service its prospective obligations to the Fund

\section{Risks}

42. The main risks to the program relate to the external environment, banking sector vulnerabilities, external financing availability, adjustment fatigue, and implementation capacity constraints. The global economic slowdown could be worse than anticipated, with adverse effects on tourism and growth. The impact of the policy change on commercial banks may be more severe than anticipated and require greater recapitalization. External financing availability may prove more difficult to mobilize than anticipated, and global financial turbulences may increase the risk of protracted discussions with private creditors, and thus compromise program financing. The move to a float will impose a heavy burden on the CBS and its administrative capacity. The social and political consensus for reform may wane under the severity of the adjustment, and pressures for fiscal and monetary relaxation emerge. The staff believes that the authorities are strongly committed to implementing the program, as demonstrated by the upfront measures already taken, in line with the understandings and are willing to take additional measures to ensure program success. In light of these risks, staff proposes quarterly program and financing assurance reviews.

\section{Staff Appraisal}

43. The staff welcomes the Seychelles authorities' commitment to implement a farreaching reform program to address the macroeconomic imbalances that have built-up over the past decades. Piecemeal reform efforts in recent years have proved insufficient to address deep-seated distortions and reduce vulnerabilities. However, since mid-2008 a strong political consensus in favor of a coherent and reform effort has emerged. Of particular 
importance is the fundamental liberalization of the exchange regime and floating of the rupee, which addresses longstanding concerns raised during previous consultations and is a key to program success. The main pillars of the authorities' program consist of a significant and sustained fiscal tightening; a reform of the monetary framework; and a reduction of the role of the state in the economy. This effort will need to be supported by a comprehensive restructuring of the public debt, which even with the domestic reform efforts would remain unsustainable.

\section{Staff commends the authorities' decision to implement a fundamental} liberalization of the exchange regime and allow the rupee to float. The maintenance of a significantly overvalued exchange rate for several years, aggravated by extensive exchange restrictions and distortionary regulations, severely constrained the economy. The early removal of these distortions represents a sea-change for Seychelles and was urgently needed to restore credibility in the rupee and unify the exchange rates. A market-determined exchange rate regime in a small open economy poses challenges, especially as the exit from the peg occurs at a time of crisis and official reserves are virtually exhausted, but there is little alternative at this juncture and the program includes provisions to contain the risks. The frontloading of access under the program is a key component of efforts to raise the likelihood of success.

45. The authorities' program includes a significant tightening of fiscal policy, which will need to sustain substantial primary surpluses over the medium term. The public sector employment retrenchment exercise, together with the replacement of indirect product subsidies by a targeted social safety net and removal of tax exemptions, are important policy reforms. The strong fiscal policy reforms already adopted or soon to be implemented form a convincing foundation for the proposed fiscal path, which is key to program success.

\section{A major strengthening of the monetary policy framework is underway, notably} in the CBS's ability to manage liquidity through indirect market-based monetary intervention. A flexible exchange rate regime places increased emphasis on monetary policy to achieve price stability. Staff encourages the authorities to maintain their efforts to tighten liquidity significantly and raise interest rates to positive real levels. Allowing domestic interest rates to rise to market determined levels is especially important in the effort to contain any potential overshooting in the nominal exchange rate, given the very limited ability to intervene in the foreign exchange market, should conditions warrant. There is a need for closer collaboration between the CBS and Ministry of Finance to improve liquidity forecasting and management. Importantly, the program includes steps to contain the risks to the financial system by bolstering banking supervision and a fiscal provision for potential recapitalization needs by state-owned financial institutions.

\section{The debt sustainability analysis clearly indicates that Seychelles' public debt is} unsustainable. The authorities have taken credible first steps in the process of elaborating and implementing a comprehensive public debt restructuring effort. Staff supports the authorities' intention to seek negotiations with external creditors on a restructuring aimed at 
reestablishing public debt sustainability, consistent with Seychelles' long-term payment capacity. In this regard, a substantial reduction in the debt service burden consistent with Seychelles' long-term ability to pay is clearly needed. Staff believe that the authorities' are in compliance with the Fund's policy on lending into arrears, based on their good faith efforts to engage with their external creditors and commitment to clear the small amount of arrears to multilateral institutions.

48. A sustained reform effort, including a major structural component, is needed over the medium term. Staff welcomes the authorities' intention to elaborate, with the support of staff and other development partners, a well-articulated medium-term structural reform agenda.

49. The program also includes several important measures to bolster public sector governance and transparency. The authorities' decision to publish the program documents and staff report - a first for Seychelles is welcome. The authorities have already initiated actions to address areas identified in the safeguards assessment. While data provided to the Fund are broadly adequate for surveillance and program monitoring, staff notes the commitment to address weaknesses in quality and timeliness of key macroeconomic data to improve their usefulness for policy formulation, with technical assistance from the Fund.

50. The staff believes that the comprehensive and frontloaded nature of the reform program merits a frontloading of access under the arrangement. Also, given the low level of reserves at the time major policy changes are implemented, staff considers frontloaded access key to ensure the success of major policy changes. While there are significant risks to the program, including from a severe global downturn, the early and important policy reforms the authorities have already undertaken are indicative of their strong ownership of the reform effort.

51. The staff recommends that the next Article IV consultation be held in accordance with the provisions of the Decision No. 12794 of July 15, 2002 on consultation cycles. 
Table 1. Seychelles: Selected Economic and Financial Indicators, 2005-13

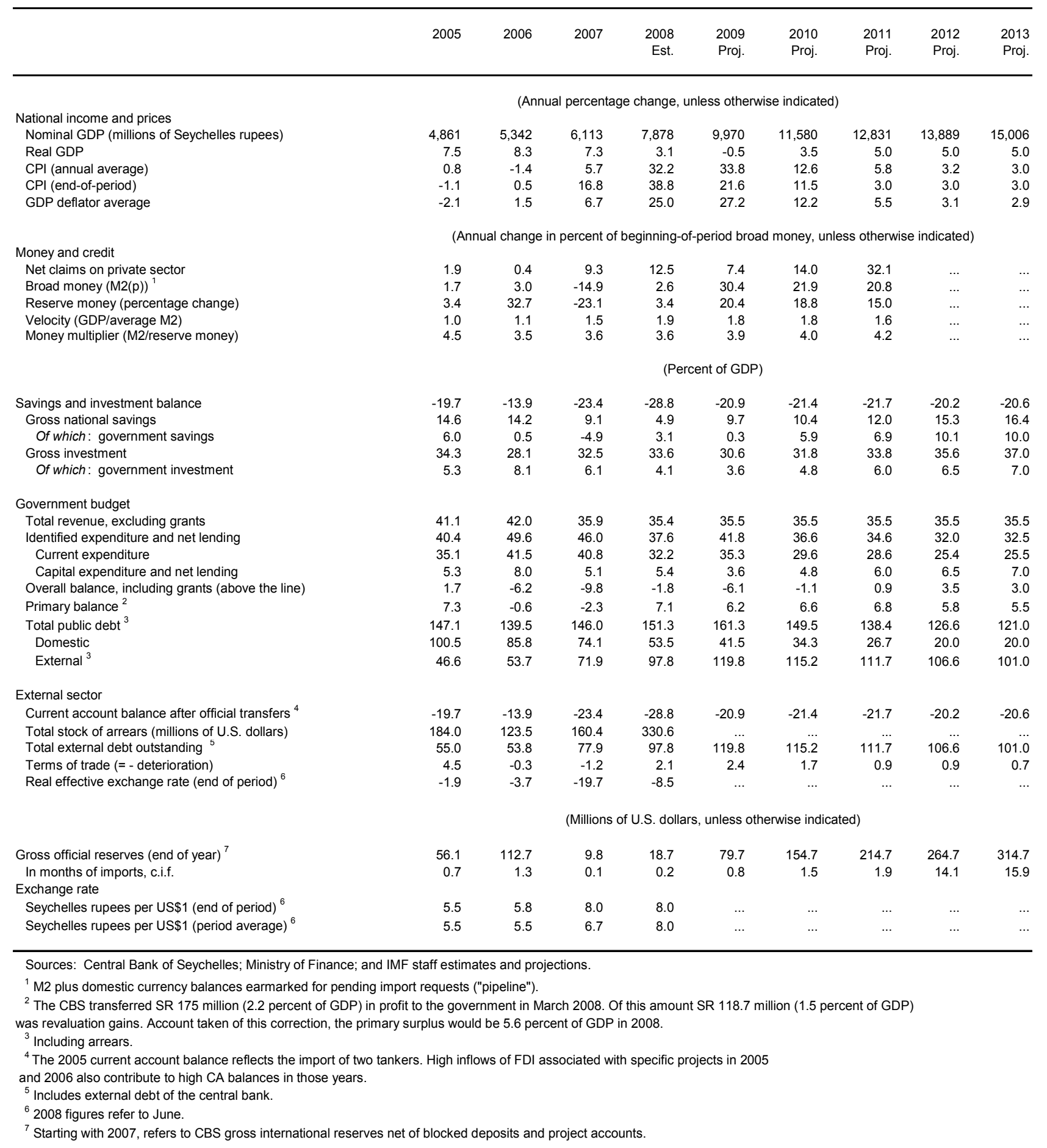


Table 2. Seychelles: Balance of Payments, 2007-09 (Millions of U.S. dollars)

\begin{tabular}{|c|c|c|c|c|c|c|c|c|c|c|c|}
\hline & \multirow{2}{*}{$\frac{2007}{\text { Act. }}$} & \multicolumn{3}{|c|}{2008} & \multirow[b]{2}{*}{ Q4 } & \multirow{2}{*}{$\frac{2008}{\text { Proj. }}$} & \multicolumn{3}{|c|}{2009} & \multirow[b]{2}{*}{ Q4 } & \multirow{2}{*}{$\frac{2009}{\text { Proj. }}$} \\
\hline & & Q1 & Q2 & Q3 & & & Q1 & Q2 & Q3 & & \\
\hline $\begin{array}{l}\text { Current account } \\
\text { (percent of GDP) }\end{array}$ & $\begin{array}{r}-213 \\
-23\end{array}$ & $\begin{array}{r}-70 \\
-7\end{array}$ & $\begin{array}{r}-83 \\
-8\end{array}$ & $\begin{array}{r}-82 \\
-8\end{array}$ & $\begin{array}{r}-12 \\
-2\end{array}$ & $\begin{array}{r}-247 \\
-29\end{array}$ & $\begin{array}{r}-23 \\
-3\end{array}$ & $\begin{array}{r}-54 \\
-8\end{array}$ & $\begin{array}{r}-33 \\
-4\end{array}$ & $\begin{array}{r}-44 \\
-6\end{array}$ & $\begin{array}{r}-153 \\
-21\end{array}$ \\
\hline $\begin{array}{l}\text { Trade balance } \\
\text { Exports of goods }\end{array}$ & $\begin{array}{r}-175 \\
392\end{array}$ & $\begin{array}{r}-68 \\
118\end{array}$ & $\begin{array}{l}-70 \\
121\end{array}$ & $\begin{array}{l}-78 \\
117\end{array}$ & $\begin{array}{r}0 \\
156\end{array}$ & $\begin{array}{r}-216 \\
511\end{array}$ & $\begin{array}{l}-13 \\
122\end{array}$ & $\begin{array}{l}-27 \\
131\end{array}$ & $\begin{array}{r}-24 \\
122\end{array}$ & $\begin{array}{l}-21 \\
158\end{array}$ & $\begin{array}{r}-85 \\
533\end{array}$ \\
\hline Of which: oil re-exports & 190 & 65 & 71 & 63 & 94 & 293 & 68 & 74 & 66 & 99 & 307 \\
\hline Of which: tuna exports & 184 & 50 & 45 & 49 & 54 & 198 & 50 & 51 & 51 & 51 & 202 \\
\hline Imports of goods & -734 & -222 & -224 & -218 & -190 & -854 & -173 & -183 & -185 & -228 & -769 \\
\hline Oil imports & -236 & -74 & -106 & -85 & -71 & -337 & -65 & -98 & -72 & -91 & -327 \\
\hline FDI-related imports & -153 & -40 & -50 & -64 & -37 & -190 & -35 & -43 & -55 & -32 & -165 \\
\hline Other & -345 & -85 & -61 & -56 & -128 & -327 & -73 & -42 & -58 & -105 & -277 \\
\hline Exports of services & 481 & 144 & 129 & 113 & 118 & 505 & 143 & 118 & 126 & 130 & 517 \\
\hline Of which: Tourism earnings & 284 & 82 & 71 & 72 & 77 & 303 & 86 & 73 & 79 & 79 & 318 \\
\hline Imports of services & -313 & -108 & -96 & -90 & -83 & -377 & -105 & -92 & -87 & -82 & -366 \\
\hline Income, net & -72 & -13 & -24 & -12 & -19 & -68 & -21 & -38 & -20 & -30 & -109 \\
\hline Of which: transfers of profits and dividends & -33 & -10 & -8 & -7 & -3 & -28 & -18 & -23 & -16 & -17 & -74 \\
\hline Of which: interest payments & -33 & -2 & -14 & -3 & -14 & -33 & -3 & -14 & -3 & -13 & -33 \\
\hline Current transfers, net & 33 & 11 & 10 & 9 & 7 & 37 & 12 & 11 & 10 & 8 & 41 \\
\hline General government, net & 10 & 4 & 3 & 4 & 2 & 14 & 5 & 5 & 6 & 3 & 19 \\
\hline Other sectors, net & 23 & 7 & 6 & 4 & 5 & 23 & 7 & 6 & 4 & 5 & 22 \\
\hline Capital and financial account & 261 & 64 & 54 & 1 & 12 & 130 & 19 & 13 & 56 & 43 & 130 \\
\hline Capital account & 8 & 0 & 0 & 0 & 4 & 4 & 1 & 1 & 1 & 1 & 6 \\
\hline Financial account & 254 & 64 & 54 & 1 & 8 & 126 & 18 & 11 & 54 & 41 & 124 \\
\hline Direct investment, net & 225 & 62 & 68 & 136 & 30 & 296 & 36 & 52 & 58 & 63 & 208 \\
\hline Portfolio investment, net & 31 & 0 & 0 & 0 & 0 & 1 & 0 & 0 & 0 & 0 & 0 \\
\hline Other investment, net & -2 & 2 & -15 & -136 & -22 & -171 & -18 & -41 & -3 & -22 & -84 \\
\hline Assets & -66 & -22 & 17 & -3 & -5 & -13 & -3 & -3 & -3 & -3 & -13 \\
\hline Liabilities & 63 & 24 & -32 & -133 & -17 & -158 & -15 & -38 & 0 & -18 & -71 \\
\hline Government and government-guaranteed & 34 & -5 & -13 & -125 & -13 & -155 & -9 & -32 & 6 & -13 & -48 \\
\hline Disbursements & 101 & 2 & 10 & 10 & 4 & 26 & 5 & 5 & 20 & 5 & 35 \\
\hline Project loans & 101 & 2 & 10 & 10 & 3 & 24 & 5 & 5 & 5 & 5 & 20 \\
\hline Program loans & 0 & 0 & 0 & 0 & 2 & 2 & 0 & 0 & 15 & 0 & 15 \\
\hline Amortization & -67 & -7 & -22 & -135 & -18 & -181 & -14 & -37 & -14 & -18 & -83 \\
\hline Parastatals & 42 & -3 & -1 & -3 & -1 & -7 & -1 & -1 & -1 & -1 & -3 \\
\hline Disbursements & 49 & 0 & 0 & 0 & 0 & 0 & 0 & 0 & 0 & 0 & 0 \\
\hline Amortization & -7 & -3 & -1 & -3 & -1 & -7 & -1 & -1 & -1 & -1 & -3 \\
\hline Other & -12 & 32 & -19 & -5 & -3 & 5 & -5 & -5 & -5 & -5 & -20 \\
\hline Net errors and omissions & -8 & 1 & 12 & 0 & 0 & 14 & 0 & 0 & 0 & 0 & 0 \\
\hline Overall balance & 40 & -5 & -17 & -81 & 0 & -104 & -3 & -41 & 22 & -1 & -23 \\
\hline Financing & -40 & 5 & 17 & 81 & 0 & 104 & -6 & 3 & -38 & -22 & -62 \\
\hline Change in net international reserves (increase: -) & 49 & -10 & 11 & 1 & 4 & 5 & -1 & 3 & -38 & -22 & -57 \\
\hline Change in gross official reserves (increase: - ) & 49 & -10 & 11 & 1 & -5 & -4 & -1 & 2 & -39 & -23 & -61 \\
\hline Prospective liabilities to IMF, net & 0 & 0 & 0 & 0 & 9 & 9 & 0 & 1 & 1 & 1 & 4 \\
\hline Other NFA (increase: -) & 0 & 0 & 0 & -54 & 0 & -54 & 0 & 0 & 0 & 0 & 0 \\
\hline Change in arrears (increase: $+{ }^{1}$ & -89 & 16 & 6 & 134 & -5 & 152 & -5 & 0 & 0 & 0 & -5 \\
\hline Of which: public sector new arrears & 6 & 5 & 3 & 131 & 31 & 170 & 0 & 0 & 0 & 0 & 0 \\
\hline Debt relief & 0 & 0 & 0 & 0 & 0 & 0 & 0 & 0 & 0 & 0 & 0 \\
\hline Financing gap & 0 & 0 & 0 & 0 & 0 & 0 & 9 & 37 & 15 & 23 & 85 \\
\hline \multicolumn{12}{|l|}{ Memorandum items: } \\
\hline Exports growth, percent & -8.2 & 17.5 & 43.1 & 21.5 & 40.1 & 30.4 & 3.3 & 8.3 & 4.3 & 1.8 & 4.3 \\
\hline Tourism growth, percent & 25.1 & 48.2 & 14.8 & 7.9 & -17.2 & 6.6 & 4.4 & 2.6 & 9.6 & 3.3 & 5.0 \\
\hline Imports growth, percent & 2.5 & 48.9 & 25.9 & 27.8 & -19.6 & 16.3 & -22.2 & -18.1 & -15.3 & 19.7 & -10.0 \\
\hline Exports, percent of GDP & 42.9 & $\ldots$ & $\ldots$ & $\ldots$ & $\ldots$ & 59.4 & $\ldots$ & $\ldots$ & $\ldots$ & $\ldots$ & 72.6 \\
\hline Imports, percent of GDP & 80.5 & $\ldots$ & $\ldots$ & $\ldots$ & $\ldots$ & 99.4 & $\ldots$ & $\ldots$ & $\ldots$ & $\ldots$ & 104.8 \\
\hline Gross international reserves (stock, e.o.p.) ${ }^{2}$ & 10 & 18 & 14 & 14 & 19 & 19 & 20 & 18 & 57 & 80 & 80 \\
\hline Months of prospective G\&S imports & 0.1 & $\cdots$ & $\ldots$ & $\cdots$ & $\ldots$ & 0.2 & $\cdots$ & $\cdots$ & $\cdots$ & $\ldots$ & 0.8 \\
\hline Scheduled public external debt service ${ }^{3,4}$ & 100 & 12 & 37 & 140 & 32 & 222 & 19 & 51 & 18 & 31 & 119 \\
\hline (Percent of G\&S exports) & 11.4 & 4.4 & 14.9 & 61.0 & 11.8 & 21.8 & 7.1 & 20.6 & 7.4 & 10.6 & 11.3 \\
\hline Public external debt ${ }^{4}$ & 710 & $\ldots$ & $\ldots$ & $\ldots$ & $\ldots$ & 840 & $\ldots$ & $\ldots$ & $\ldots$ & $\ldots$ & 880 \\
\hline (percent of GDP) & 77.9 & $\ldots$ & $\ldots$ & $\ldots$ & $\ldots$ & 97.8 & $\ldots$ & $\ldots$ & $\ldots$ & $\ldots$ & 119.8 \\
\hline Of which: arrears ${ }^{3,4}$ & 160 & $\ldots$ & $\ldots$ & $\ldots$ & $\ldots$ & 331 & $\ldots$ & $\ldots$ & $\ldots$ & $\ldots$ & 331 \\
\hline (percent of GDP) & 17.6 & $\ldots$ & $\ldots$ & $\ldots$ & $\ldots$ & 38.5 & $\ldots$ & $\ldots$ & $\ldots$ & $\ldots$ & 45.0 \\
\hline GDP & 912 & 985 & 985 & 985 & 622 & 859 & 696 & 712 & 767 & 767 & 734 \\
\hline
\end{tabular}

${ }^{1}$ In 2008, includes accelerated promissory notes. In 2008-09, includes repayment of accrued investor profits.

${ }^{2}$ Starting with 2007, refers to CBS gross international reserves net of blocked deposits and project accounts.

${ }^{3}$ Debt service projections are based on exhisting stock of debt and identified new borrowing, assuming no debt restructuring and no repayment of arrears.

${ }^{4}$ Preliminary and subject to reconcilliation with creditors. 
Table 3. Seychelles: Consolidated Government Operations, 2007-10 ${ }^{1}$

\begin{tabular}{|c|c|c|c|c|c|c|c|c|c|c|c|c|c|}
\hline & \multirow{2}{*}{$\begin{array}{r}2007 \\
\text { Act. }\end{array}$} & \multicolumn{3}{|c|}{2008} & \multicolumn{3}{|c|}{2008} & \multicolumn{3}{|c|}{2009} & \multicolumn{2}{|r|}{2009} & \multirow{2}{*}{$\begin{array}{l}2010 \\
\text { Prog. }\end{array}$} \\
\hline & & $\begin{array}{r}\text { Q1 } \\
\text { Act. }\end{array}$ & $\begin{array}{r}\text { Q2 } \\
\text { Act. } \\
\end{array}$ & $\begin{array}{l}\text { Q3 } \\
\text { Est. }\end{array}$ & $\begin{array}{r}\text { Q4 } \\
\text { Prog. } \\
\end{array}$ & Prog. & Budget & $\begin{array}{r}\text { Q1 } \\
\text { Prog. } \\
\end{array}$ & $\begin{array}{r}\text { Q2 } \\
\text { Prog. } \\
\end{array}$ & $\begin{array}{r}\text { Q3 } \\
\text { Prog. } \\
\end{array}$ & $\begin{array}{l}\text { Q4 } \\
\text { Prog. } \\
\end{array}$ & Prog. & \\
\hline & \multicolumn{13}{|c|}{ (Millions of Seychelles rupees) } \\
\hline Total revenue and grants & $2,214.2$ & 742.7 & 532.5 & 702.0 & 849.4 & $2,826.6$ & $2,491.3$ & 826.2 & 759.4 & 925.2 & $1,053.0$ & $3,563.7$ & $4,111.6$ \\
\hline Total revenue & $2,197.5$ & 740.9 & 529.6 & 670.1 & 845.4 & $2,786.1$ & $2,476.2$ & 821.2 & 754.4 & 920.2 & $1,048.0$ & $3,543.7$ & $4,111.6$ \\
\hline Tax & $1,896.4$ & 527.4 & 492.9 & 612.9 & 711.2 & $2,344.5$ & $2,139.1$ & 695.8 & 702.8 & 848.9 & 886.1 & $3,133.5$ & $3,657.2$ \\
\hline Social Security Tax & 301.3 & 76.9 & 82.2 & 97.3 & 64.4 & 320.8 & 314.4 & 77.4 & 88.0 & 91.5 & 95.0 & 352.0 & 414.1 \\
\hline Trade tax & 265.2 & 90.2 & 75.7 & 98.1 & 160.0 & 424.0 & 360.0 & 115.0 & 132.3 & 155.3 & 172.5 & 575.0 & 612.3 \\
\hline Goods and Services Tax (GST) & 799.6 & 210.4 & 211.9 & 201.6 & 292.3 & 916.2 & 920.0 & 336.4 & 343.5 & 352.5 & 409.6 & $1,442.0$ & $1,747.0$ \\
\hline Business tax & 360.5 & 96.8 & 97.5 & 172.5 & 150.0 & 516.8 & 359.1 & 106.1 & 107.8 & 168.7 & 168.5 & 551.0 & 640.0 \\
\hline Other & 169.8 & 53.1 & 25.6 & 43.5 & 44.5 & 166.7 & 185.6 & 60.9 & 31.3 & 80.9 & 40.4 & 213.5 & 243.8 \\
\hline Nontax & 301.1 & 213.5 & 36.7 & 57.2 & 134.2 & 441.7 & 337.1 & 125.4 & 51.6 & 71.4 & 161.9 & 410.3 & 454.4 \\
\hline Fees and charges & 175.8 & 32.6 & 32.6 & 24.7 & 35.5 & 125.4 & 90.9 & 43.1 & 41.0 & 38.9 & 42.1 & 165.1 & 202.8 \\
\hline Dividends from parastatals & 94.8 & -0.9 & 0.0 & 23.1 & 89.6 & 111.8 & 112.0 & 0.0 & 0.0 & 16.0 & 107.0 & 123.0 & 110.0 \\
\hline Other ${ }^{2}$ & 30.5 & 181.8 & 4.1 & 9.4 & 9.2 & 204.5 & 134.2 & 82.3 & 10.6 & 16.4 & 12.8 & 122.1 & 141.6 \\
\hline External grants & 16.7 & 1.7 & 2.8 & 31.8 & 4.0 & 40.4 & 15.1 & 5.0 & 5.0 & 5.0 & 5.0 & 20.0 & 0.0 \\
\hline Expenditure and net lending & $2,810.2$ & 614.5 & 673.7 & 599.1 & $1,078.1$ & $2,965.4$ & $2,458.7$ & $1,000.6$ & $1,145.8$ & 950.8 & $1,073.9$ & $4,171.2$ & $4,233.5$ \\
\hline Current expenditure & $2,497.2$ & 498.5 & 625.8 & 520.2 & 896.0 & $2,540.4$ & $2,148.7$ & 829.1 & 963.7 & 804.7 & 917.2 & $3,514.7$ & $3,429.5$ \\
\hline Primary current expenditure & $2,041.5$ & 422.9 & 459.4 & 432.5 & 526.5 & $1,841.2$ & $1,715.5$ & 581.7 & 561.7 & 568.3 & 573.5 & $2,285.4$ & $2,546.2$ \\
\hline Wages and salaries & 699.7 & 163.1 & 168.6 & 150.9 & 238.0 & 720.6 & 678.6 & 206.9 & 180.1 & 180.1 & 180.1 & 747.2 & 739.4 \\
\hline Goods and services & 499.8 & 87.7 & 121.4 & 103.1 & 134.9 & 447.0 & 410.2 & 146.7 & 151.9 & 161.2 & 165.3 & 625.0 & 725.9 \\
\hline Interest payments due & 455.8 & 75.6 & 166.4 & 87.6 & 369.5 & 699.1 & 433.3 & 247.4 & 402.0 & 236.3 & 343.7 & $1,229.4$ & 883.3 \\
\hline Foreign interest $^{3}$ & 219.4 & 17.4 & 112.8 & 22.5 & 191.0 & 343.7 & 215.2 & 43.8 & 196.3 & 41.0 & 181.4 & 462.5 & 425.2 \\
\hline Domestic interest & 236.4 & 58.2 & 53.6 & 65.2 & 178.5 & 355.4 & 218.0 & 203.5 & 205.7 & 195.4 & 162.3 & 766.9 & 458.1 \\
\hline Transfers & 833.6 & 171.2 & 167.8 & 178.4 & 150.3 & 667.6 & 620.2 & 226.2 & 227.7 & 225.0 & 226.1 & 905.1 & $1,071.8$ \\
\hline Social program of central government & 166.7 & 42.1 & 48.7 & 56.9 & 45.8 & 193.5 & 121.3 & 88.3 & 89.8 & 88.3 & 89.3 & 355.8 & 476.2 \\
\hline Transfers to public sector from central government & 375.6 & 58.9 & 47.2 & 46.7 & 29.6 & 182.3 & 194.6 & 45.6 & 45.6 & 44.4 & 44.5 & 180.1 & 156.9 \\
\hline Benefits and programs of Social Security Fund & 291.3 & 70.2 & 71.9 & 74.8 & 74.9 & 291.8 & 304.4 & 92.3 & 92.3 & 92.3 & 92.3 & 369.2 & 438.8 \\
\hline Other & 8.3 & 0.9 & 1.6 & 0.2 & 3.3 & 6.0 & 6.4 & 2.0 & 2.0 & 2.0 & 2.0 & 8.0 & 9.1 \\
\hline $\begin{array}{l}\text { Capital expenditure } \\
\text { Externally financed }\end{array}$ & 375.7 & 23.0 & 63.7 & 69.9 & 167.5 & 324.2 & 310.0 & 71.5 & 82.1 & 96.1 & 106.7 & 356.4 & 554.0 \\
\hline Net lending & -62.7 & 93.0 & -15.9 & 9.0 & 14.6 & 100.8 & 0.0 & 0.0 & 0.0 & 0.0 & 0.0 & 0.0 & 0.0 \\
\hline Contingency ${ }^{4}$ & & & & & & & & 100.0 & 100.0 & 50.0 & 50.0 & 300.0 & 250.0 \\
\hline Primary balance, commitment basis ${ }^{2}$ & -140.3 & 203.8 & 25.3 & 190.5 & 140.8 & 560.3 & 465.9 & 72.9 & 15.6 & 210.7 & 322.8 & 622.0 & 761.4 \\
\hline Overall balance, commitment basis & -596.1 & 128.2 & -141.2 & 102.9 & -228.7 & -138.8 & 32.6 & -174.5 & -386.4 & -25.6 & -20.9 & -607.4 & -121.9 \\
\hline Change in arrears & 59.4 & 14.5 & -15.0 & 1.4 & -0.3 & 0.5 & 0.0 & 0.0 & 0.0 & -181.4 & 0.0 & -181.4 & 0.0 \\
\hline External interest & 3.9 & 11.8 & -15.3 & 14.0 & 0.0 & 10.5 & 0.0 & 0.0 & 0.0 & 0.0 & 0.0 & 0.0 & 0.0 \\
\hline Domestic budget & 55.5 & 2.8 & 0.2 & -12.7 & -0.3 & -10.0 & 0.0 & 0.0 & 0.0 & -181.4 & 0.0 & -181.4 & 0.0 \\
\hline Overall balance, cash basis (after grants) & -536.7 & 142.7 & -156.2 & 104.2 & -229.0 & -138.2 & 32.6 & -174.5 & -386.4 & -207.0 & -20.9 & -788.8 & -121.9 \\
\hline Cash balance before external debt service & -317.3 & 160.1 & -43.3 & 126.7 & -38.0 & 205.5 & 247.8 & -130.6 & -190.1 & -166.0 & 160.5 & -326.3 & 303.3 \\
\hline Financing & 536.7 & -142.7 & 156.2 & -104.2 & 229.0 & 138.2 & -32.6 & 42.9 & -137.4 & -7.6 & -296.3 & -398.4 & -404.6 \\
\hline Foreign financing (cash basis, net) & 408.1 & -33.9 & -67.6 & 16.8 & 232.1 & 147.3 & 475.5 & -150.7 & -450.0 & 64.4 & -178.1 & -714.4 & -330.3 \\
\hline Foreign financing (accrual basis, net) & 410.8 & -63.0 & -107.0 & $-1,019.1$ & -199.5 & $-1,388.7$ & & -150.7 & -450.0 & 64.4 & -178.1 & -714.4 & -330.3 \\
\hline Disbursements & 859.4 & 12.3 & 78.3 & 81.2 & 60.8 & 232.6 & 250.6 & 70.0 & 70.0 & 280.0 & 70.0 & 490.0 & 502.8 \\
\hline Project loans & 859.4 & 12.3 & 78.3 & 81.2 & 39.2 & 211.0 & 250.6 & 70.0 & 70.0 & 70.0 & 70.0 & 280.0 & 287.3 \\
\hline Program/Budget Support & 0.0 & 0.0 & 0.0 & 0.0 & 21.6 & 21.6 & $\ldots$ & 0.0 & 0.0 & 210.0 & 0.0 & 210.0 & 215.5 \\
\hline Amortization due ${ }^{3}$ & -448.6 & -75.3 & -185.3 & $-1,100.4$ & -260.3 & $-1,621.3$ & -224.9 & -220.7 & -520.0 & -215.6 & -248.1 & $-1,204.4$ & -833.1 \\
\hline Change in amortization arrears & -2.7 & 29.0 & 39.4 & $1,035.9$ & 431.6 & $1,536.0$ & $\ldots$ & 0.0 & 0.0 & 0.0 & 0.0 & 0.0 & 0.0 \\
\hline Debt relief & 0.0 & 0.0 & 0.0 & 0.0 & 0.0 & 0.0 & & 0.0 & 0.0 & 0.0 & 0.0 & 0.0 & 0.0 \\
\hline Domestic financing, net & -19.5 & -87.2 & 184.2 & -171.1 & -144.4 & -218.6 & -722.4 & 108.1 & 276.6 & -174.0 & -289.0 & -78.3 & -163.4 \\
\hline Bank financing & -50.3 & -109.2 & 159.0 & -162.6 & -137.2 & -249.9 & $\ldots$ & 102.7 & 262.8 & -165.3 & -274.5 & -74.4 & -155.2 \\
\hline Nonbank & 30.7 & 22.0 & 25.1 & -8.6 & -7.2 & 31.4 & $\ldots$ & 5.4 & 13.8 & -8.7 & -14.4 & -3.9 & -8.2 \\
\hline Privatization and long-term lease of fixed assets & 134.3 & 42.2 & 22.2 & 50.2 & 141.4 & 256.0 & 214.3 & 85.6 & 36.0 & 102.0 & 170.8 & 394.3 & 89.2 \\
\hline Statistical discrepancy & 13.9 & -63.8 & 17.4 & 0.0 & 0.0 & -46.4 & $\ldots$ & 0.0 & 0.0 & 0.0 & 0.0 & 0.0 & 0.0 \\
\hline Fiscal financing gap & 0.0 & 0.0 & 0.0 & 0.0 & 0.0 & 0.0 & $\ldots$ & 131.5 & 523.9 & 214.6 & 317.2 & $1,187.2$ & 526.5 \\
\hline \multicolumn{14}{|l|}{ Memorandum items: } \\
\hline External debt service due ${ }^{3}$ & 667.9 & 92.7 & 298.1 & $1,122.8$ & 451.3 & $1,965.0$ & 440.1 & 264.5 & 716.3 & 256.6 & 429.5 & $1,666.9$ & $1,258.4$ \\
\hline
\end{tabular}

Sources: Ministry of Finance; Social Security Fund; Pension Fund; Central Bank of Seychelles (CBS); and IMF staff estimates and projections.

Includes the central government and the social security system.

${ }^{2}$ The CBS transferred SR 175 million (2.2 percent of GDP) in profit to the government in March 2008. Of this amount SR 118.7 million (1.5 percent of GDP) was revaluation gains.

Account taken of this correction, the primary surplus would be 5.6 percent of GDP in 2008.

${ }^{3}$ Includes debt service on existing debt and on identified financing.

${ }^{4}$ This is created to cover potential losses in state-controlled financial institutions. 
Table 3. Seychelles: Consolidated Government Operations, $2007-10^{1}$ (concluded)

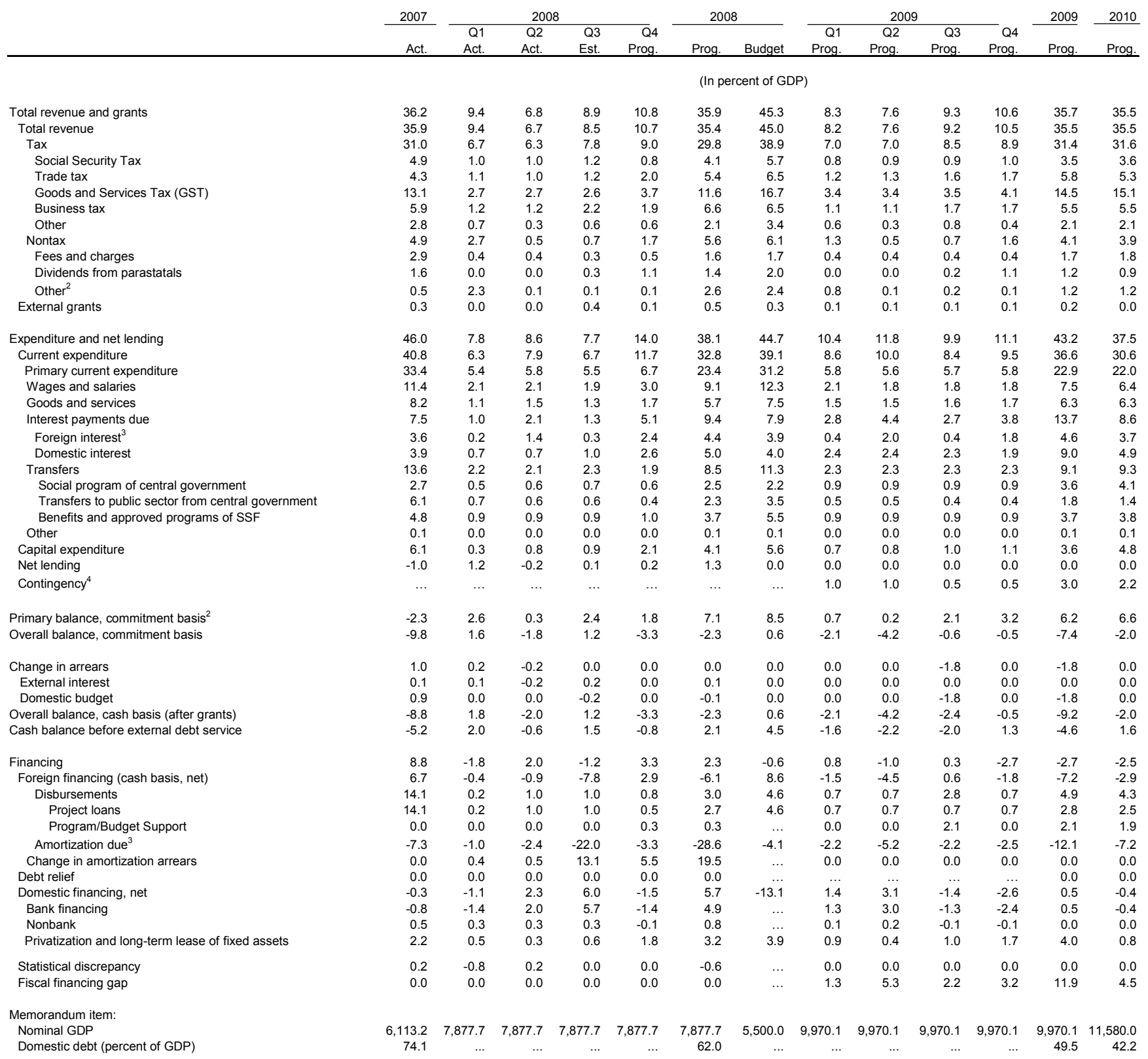

Sources: Ministry of Finance; Social Security Fund; Pension Fund; Central Bank of Seychelles (CBS); and IMF staff estimates and projections.

${ }^{1}$ Includes the central government and the social security system.

${ }^{2}$ The CBS transferred SR 175 million (2.2 percent of GDP) in profit to the government in March 2008. Of this amount SR 118.7 million (1.5

percent of GDP) was revaluation gains. Account taken of this correction, the primary surplus would be 5.6 percent of GDP in 2008.

${ }^{3}$ Includes debt service on existing debt and on identified financing.

${ }^{4}$ This is created to cover potential losses in state-controlled financial institutions. 
Table 4. Seychelles: Monetary Survey and Central Bank Accounts, 2007-09

\begin{tabular}{|c|c|c|c|c|c|c|c|c|c|c|c|c|}
\hline & \multicolumn{4}{|c|}{2007} & \multicolumn{4}{|c|}{2008} & \multicolumn{4}{|c|}{2009} \\
\hline & Mar. & Jun. & Sep. & Dec. & Mar. & Jun. & Sep. & Dec. & Mar. & Jun. & Sep. & Dec. \\
\hline & \multicolumn{4}{|c|}{ Act. } & Act. & Act. & Proj. & Proj. & \multicolumn{4}{|c|}{ Projections } \\
\hline & \multirow{2}{*}{\multicolumn{12}{|c|}{ (Seychelles rupees millions, unless otherwise indicated) }} \\
\hline Monetary Survey & & & & & & & & & & & & \\
\hline Net foreign assets & 740.1 & 598.5 & 580.1 & 423.4 & 423.0 & 482.8 & 992.1 & $1,738.1$ & $1,822.1$ & $1,844.2$ & $2,443.1$ & $2,814.2$ \\
\hline Central bank & 739.1 & 698.9 & 477.4 & 322.5 & 406.3 & 319.5 & 775.9 & $1,320.3$ & $1,334.3$ & $1,286.5$ & $1,815.3$ & $2,116.4$ \\
\hline Deposit money banks & 1.0 & -100.4 & 102.6 & 100.9 & 16.8 & 163.3 & 216.2 & 417.7 & 487.7 & 557.7 & 627.7 & 697.7 \\
\hline Net domestic assets & $4,443.6$ & $4,662.4$ & $3,863.6$ & $4,214.7$ & $4,255.2$ & $4,362.2$ & $4,484.8$ & $3,694.8$ & $3,748.3$ & $4,024.9$ & $4,039.6$ & 3,922.4 \\
\hline Domestic credit & $4,875.1$ & $5,209.4$ & $5,215.9$ & $5,108.1$ & $5,104.7$ & $5,300.3$ & $5,401.9$ & $5,358.2$ & $5,413.6$ & $5,687.2$ & $5,704.0$ & $5,588.7$ \\
\hline Net claims on the government & $3,361.4$ & $3,573.1$ & $3,396.2$ & $3,178.2$ & $3,069.0$ & $3,228.1$ & $3,065.5$ & $2,928.3$ & $3,030.9$ & $3,293.7$ & $3,128.4$ & $2,853.9$ \\
\hline Credit to the economy & $1,513.6$ & $1,636.3$ & $1,819.7$ & $1,929.9$ & $2,035.6$ & $2,072.3$ & $2,336.4$ & $2,429.9$ & $2,382.7$ & $2,393.5$ & $2,575.5$ & $2,734.8$ \\
\hline Other items, net (assets $=+$ ) & -431.5 & -547.0 & $-1,352.3$ & -893.4 & -849.4 & -938.2 & -917.1 & $-1,663.3$ & $-1,665.3$ & $-1,662.3$ & $-1,664.3$ & $-1,666.3$ \\
\hline M3 & $5,209.8$ & $5,290.9$ & $4,470.9$ & $4,680.9$ & $4,716.3$ & $4,874.0$ & $5,476.9$ & $5,432.9$ & $5,570.4$ & $5,869.1$ & $6,482.7$ & $6,736.6$ \\
\hline Foreign currency deposits & 407.2 & 327.8 & 521.2 & 639.7 & 746.5 & 680.2 & 719.9 & $1,288.0$ & $1,330.0$ & $1,330.0$ & $1,330.0$ & $1,330.0$ \\
\hline M2 & $4,802.6$ & $4,963.1$ & $3,949.7$ & $4,041.2$ & $3,969.8$ & $4,193.8$ & $4,757.0$ & $4,144.9$ & $4,240.4$ & $4,539.1$ & $5,152.7$ & $5,406.6$ \\
\hline Currency in circulation & 410.1 & 421.1 & 418.1 & 450.6 & 442.4 & 447.7 & 443.2 & 477.6 & 468.9 & 474.6 & 469.8 & 506.3 \\
\hline Local currency deposits & $4,392.5$ & $4,542.0$ & $3,531.5$ & $3,590.6$ & $3,527.4$ & $3,746.1$ & $4,313.8$ & $3,667.3$ & $3,771.4$ & $4,064.5$ & $4,682.9$ & $4,900.2$ \\
\hline \multicolumn{13}{|l|}{ Central Bank } \\
\hline Net foreign assets & 739.1 & 698.9 & 477.5 & 322.5 & 406.3 & 319.5 & 775.9 & $1,320.3$ & $1,334.3$ & $1,286.5$ & $1,815.3$ & $2,116.4$ \\
\hline Foreign assets & 739.1 & 698.9 & 477.5 & 322.5 & 406.3 & 319.5 & 775.9 & $1,451.7$ & $1,465.7$ & $1,437.2$ & $1,985.3$ & $2,305.7$ \\
\hline Of which: official reserves & 739.1 & 698.9 & 477.4 & 78.6 & 141.1 & 113.9 & 109.5 & 261.7 & 275.7 & 247.2 & 795.3 & $1,115.7$ \\
\hline Foreign liabilities & 0.0 & 0.0 & 0.0 & 0.0 & 0.0 & 0.0 & 0.0 & 131.4 & 131.4 & 150.7 & 170.0 & 189.3 \\
\hline Of which: use of Fund resources & -1.0 & 0.0 & 0.0 & 0.0 & 0.0 & 0.0 & 0.0 & 131.3 & 131.3 & 150.6 & 169.9 & 189.3 \\
\hline Net domestic assets & 949.4 & 923.8 & 605.4 & 790.5 & 734.5 & 962.8 & 495.2 & -169.0 & -188.3 & -25.6 & -422.7 & -730.1 \\
\hline Domestic credit & $1,073.5$ & $1,099.0$ & $1,349.2$ & $1,102.6$ & 894.6 & $1,093.5$ & 629.4 & 549.3 & 532.0 & 691.7 & 296.6 & -8.8 \\
\hline Government (net) & $1,073.5$ & $1,099.0$ & $1,342.2$ & $1,102.6$ & 894.6 & $1,063.7$ & $1,046.6$ & $1,032.2$ & $1,043.0$ & $1,070.7$ & $1,053.3$ & $1,024.4$ \\
\hline Nongovernment credit & 0.0 & 0.0 & 7.0 & 0.0 & 0.0 & 29.7 & -417.2 & -482.9 & -511.0 & -379.0 & -756.7 & $-1,033.2$ \\
\hline Other items, net & -124.1 & -175.2 & -743.8 & -312.1 & -160.0 & -130.7 & -134.2 & -718.3 & -720.3 & -717.3 & -719.3 & -721.3 \\
\hline Reserve money & $1,688.5$ & $1,622.7$ & $1,082.8$ & $1,113.1$ & $1,140.8$ & $1,282.3$ & $1,271.1$ & $1,151.4$ & $1,146.0$ & $1,260.9$ & $1,392.6$ & $1,386.3$ \\
\hline \multicolumn{13}{|l|}{ Memorandum items: } \\
\hline Gross international reserves (millions of U.S. dollars) & 121.2 & 110.9 & 66.4 & 9.8 & 17.7 & 14.3 & 13.7 & 18.7 & 19.7 & 17.7 & 56.8 & 79.7 \\
\hline Foreign Currency Deposits (millions of U.S. dollars) & 66.8 & 52.0 & 72.5 & 80.0 & 93.5 & 85.4 & 90.0 & 92.0 & 95.0 & 95.0 & 95.0 & 95.0 \\
\hline M2 growth (12-month percent change) & 3.7 & 4.7 & -18.2 & -14.9 & -17.3 & -15.5 & 20.4 & 2.6 & 6.8 & 8.2 & 8.3 & 30.4 \\
\hline M3 growth (12-month percent change) & 6.5 & 5.8 & -13.1 & -7.6 & -9.5 & -7.9 & 22.5 & 16.1 & 18.1 & 20.4 & 18.4 & 24.0 \\
\hline Credit to the economy (12-month percent change) & 17.7 & 20.8 & 37.0 & 32.7 & 34.5 & 26.6 & 28.4 & 25.9 & 17.1 & 15.5 & 10.2 & 12.5 \\
\hline Reserve money (12-month percent change) & 54.9 & 48.5 & -0.6 & -23.1 & -32.4 & -21.0 & 17.4 & 3.4 & 0.5 & -1.7 & 9.6 & 20.4 \\
\hline Money multiplier (M2/reserve money) & 2.8 & 3.1 & 3.6 & 3.6 & 3.5 & 3.3 & 3.7 & 3.6 & 3.7 & 3.6 & 3.7 & 3.9 \\
\hline Velocity (GDP/M2; end of period) & 1.2 & 1.2 & 1.5 & 1.5 & 1.6 & 1.7 & 1.6 & 1.9 & 2.0 & 2.0 & 1.8 & 1.8 \\
\hline Velocity (GDP/M3; end of period) & 1.1 & 1.1 & 1.3 & 1.3 & 1.4 & 1.4 & 1.4 & 1.5 & 1.5 & 1.5 & 1.5 & 1.5 \\
\hline Changes in Net Credit to Government (millions of rupees) & 133.0 & 211.7 & -176.9 & -218.0 & -109.2 & 159.0 & -162.6 & -137.2 & 102.7 & 262.8 & -165.3 & -274.5 \\
\hline Real M2 Index $($ Mar.06 $=100)$ & 102.0 & 104.1 & 78.0 & 74.4 & 65.5 & 67.0 & 70.1 & 55.0 & 51.0 & 51.4 & 57.1 & 59.0 \\
\hline Real M3 Index (Mar.06 $=100)$ & 104.7 & 105.0 & 83.6 & 81.6 & 73.7 & 73.7 & 76.4 & 68.3 & 63.4 & 63.0 & 68.0 & 69.6 \\
\hline
\end{tabular}

Sources: Central Bank of Seychelles, and IMF staff estimates and projections. 
Table 5. Seychelles: Public Sector External Debt, 2006-08 ${ }^{1}$

\begin{tabular}{|c|c|c|c|c|}
\hline & $2006^{2}$ & 2007 & 2008 & 2008 \\
\hline & & & end-June & end-Aug \\
\hline & \multicolumn{4}{|c|}{ (millions of U.S. dollars) } \\
\hline Public sector external debt & 514.1 & 710.2 & 793.3 & 808.9 \\
\hline Multilateral & 40.7 & 50.6 & 48.4 & 53.9 \\
\hline Bilateral & 178.8 & 205.4 & 217.2 & 249.3 \\
\hline Paris Club & 131.9 & 149.2 & 155.3 & 154.2 \\
\hline Others & 47.0 & 56.2 & 61.9 & 95.1 \\
\hline Commercial & 294.6 & 454.2 & 527.7 & 505.6 \\
\hline Banks & 94.6 & 100.3 & 168.7 & 153.3 \\
\hline \multirow[t]{2}{*}{ Securities } & 200.0 & 353.9 & 359.0 & 352.3 \\
\hline & \multicolumn{4}{|c|}{ (millions of U.S. dollars) } \\
\hline Arrears & 123.5 & 162.5 & 180.0 & 313.7 \\
\hline Multilateral & 0.3 & 3.0 & 1.3 & 2.2 \\
\hline Bilateral & 103.8 & 134.9 & 147.4 & 162.5 \\
\hline Paris Club & 100.2 & 119.8 & 126.5 & 119.1 \\
\hline Others & 3.6 & 15.1 & 20.9 & 43.4 \\
\hline Commercial & 19.4 & 24.6 & 31.3 & 149.0 \\
\hline Banks & 19.4 & 24.6 & 31.3 & 26.8 \\
\hline Securities & 0.0 & 0.0 & 0.0 & 122.3 \\
\hline \multicolumn{5}{|l|}{ Memorandum items: } \\
\hline Nominal GDP (millions of Seychelles rupees) & 5,342 & 6,113 & 7,878 & 7,878 \\
\hline Nominal GDP (millions of U.S. dollars) & 968 & 912 & 859 & 859 \\
\hline
\end{tabular}

Sources: Ministry of Finance; Central Bank of Seychelles, and IMF staff calculations.

1 Preliminary and subject to reconciliation with creditors.

${ }^{2}$ Excludes external liabilities of the Central Bank of Seychelles. 
Table 6. Seychelles: Scheduled public sector external debt service, annual, $2007-13^{1}$ (millions of U.S. dollars)

\begin{tabular}{|c|c|c|c|c|c|c|c|c|c|c|c|c|}
\hline & $\begin{array}{r}2007 \\
\text { Act. }\end{array}$ & 2008 & 2009 & 2010 & 2011 & 2012 & 2013 & 2014 & 2015 & 2016 & 2017 & 2018 \\
\hline Public sector external debt service & 93.82 & 99.67 & 117.09 & 85.28 & 284.36 & 15.60 & 12.17 & 10.23 & 4.59 & 4.03 & 3.59 & 2.86 \\
\hline Amortization & 61.66 & 66.93 & 86.03 & 57.99 & 259.52 & 13.10 & 10.21 & 8.67 & 3.87 & 3.44 & 3.10 & 2.47 \\
\hline Multilateral & 8.92 & 4.73 & 24.58 & 3.69 & 3.52 & 2.03 & 2.09 & 1.96 & 1.89 & 1.93 & 1.96 & 1.35 \\
\hline Bilateral & 8.14 & 23.64 & 15.72 & 15.59 & 12.02 & 9.41 & 8.11 & 6.72 & 1.97 & 1.51 & 1.14 & 1.12 \\
\hline Paris Club & 3.78 & 3.95 & 3.72 & 3.46 & 2.77 & 2.76 & 2.76 & 2.72 & 0.64 & 0.64 & 0.46 & 0.46 \\
\hline Others & 4.36 & 19.69 & 12.01 & 12.13 & 9.25 & 6.65 & 5.36 & 4.00 & 1.33 & 0.87 & 0.68 & 0.66 \\
\hline Commercial & 44.60 & 38.56 & 45.73 & 38.71 & 243.98 & 1.66 & 0.00 & 0.00 & 0.00 & 0.00 & 0.00 & 0.00 \\
\hline Banks & 44.60 & 36.85 & 45.73 & 38.71 & 13.98 & 1.66 & 0.00 & 0.00 & 0.00 & 0.00 & 0.00 & 0.00 \\
\hline Securities & 0.00 & 1.71 & 0.00 & 0.00 & 230.00 & 0.00 & 0.00 & 0.00 & 0.00 & 0.00 & 0.00 & 0.00 \\
\hline Interest forecast & 32.16 & 32.73 & 31.06 & 27.29 & 24.84 & 2.50 & 1.96 & 1.55 & 0.72 & 0.60 & 0.49 & 0.39 \\
\hline Multilateral & 2.15 & 1.78 & 1.82 & 0.89 & 0.74 & 0.61 & 0.54 & 0.47 & 0.40 & 0.34 & 0.27 & 0.22 \\
\hline Bilateral & 2.39 & 3.48 & 3.69 & 3.34 & 2.76 & 1.85 & 1.43 & 1.09 & 0.32 & 0.26 & 0.21 & 0.18 \\
\hline Paris Club & 1.80 & 1.37 & 1.14 & 0.93 & 0.73 & 0.55 & 0.38 & 0.20 & 0.07 & 0.05 & 0.04 & 0.03 \\
\hline Others & 0.59 & 2.11 & 2.55 & 2.42 & 2.04 & 1.30 & 1.05 & 0.89 & 0.25 & 0.20 & 0.17 & 0.14 \\
\hline Commercial & 27.62 & 27.47 & 25.55 & 23.06 & 21.33 & 0.05 & 0.00 & 0.00 & 0.00 & 0.00 & 0.00 & 0.00 \\
\hline Banks & 6.63 & 6.48 & 4.57 & 2.07 & 0.35 & 0.05 & 0.00 & 0.00 & 0.00 & 0.00 & 0.00 & 0.00 \\
\hline Securities & 20.99 & 20.99 & 20.99 & 20.99 & 20.99 & 0.00 & 0.00 & 0.00 & 0.00 & 0.00 & 0.00 & 0.00 \\
\hline \multicolumn{13}{|l|}{ Memorandum item: } \\
\hline Arrears outstanding ${ }^{2}$ & 162.49 & 313.70 & & & & & & & & & & \\
\hline
\end{tabular}

Sources: Ministry of Finance and IMF staff calculations.

${ }^{1}$ All data are preliminary and subject to reconcilliation with creditors. Debt service is on existing external debt as of end-August 2008 . Does not include service on program financing, new lending, and arrears repayment.

${ }^{2}$ For 2008, at end-Aug. 
Table 7. Seychelles: Financial Soundness Indicators for the Banking Sector, 2002-08

(Percent, at period's end, unless otherwise indicated)

\begin{tabular}{|c|c|c|c|c|c|c|c|}
\hline & 2002 & 2003 & 2004 & 2005 & 2006 & 2007 & $\frac{2008}{\text { June }}$ \\
\hline \multicolumn{8}{|l|}{ Financial Sector Indicators } \\
\hline Regulatory capital to risk-weighted assets & 31.8 & 20.9 & 21.6 & 20.3 & 19.6 & 15.4 & 17.0 \\
\hline Capital (net worth) to assets & 5.2 & 5.4 & 5.9 & 6.2 & 6.6 & 6.9 & 7.0 \\
\hline Foreign exchange loans to total loans & 2.3 & 8.1 & 9.5 & 14.5 & 21.8 & 30.8 & 32.9 \\
\hline Non-performing loans to gross loans & 2.5 & 3.0 & 5.1 & 3.6 & 4.4 & 2.3 & 2.1 \\
\hline Substandard loans to gross loans & 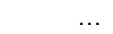 & $\ldots$ & $\ldots$ & 0.4 & 1.9 & $\ldots$ & \\
\hline Provision as percent of non-performing loans & 51.8 & 54.9 & 40.9 & 45.9 & 35.2 & 45.9 & 50.3 \\
\hline \multicolumn{8}{|l|}{ Sectoral distribution of loans } \\
\hline Agriculture and horticulture & $\ldots$ & $\ldots$ & 0.1 & 0.1 & 0.3 & 0.6 & 0.7 \\
\hline Building and construction & $\ldots$ & $\ldots$ & 6.4 & 5.6 & 5.1 & 4.1 & 4.5 \\
\hline Financial institutions & $\ldots$ & $\ldots$ & 10.2 & 14.3 & 7.3 & 8.2 & 9.5 \\
\hline Fishing & $\ldots$ & $\ldots$ & 0.8 & 0.6 & 0.4 & 0.1 & 0.2 \\
\hline Manufacturing & $\ldots$ & $\ldots$ & 0.6 & 0.5 & 0.8 & 0.7 & 0.6 \\
\hline Real estate & $\ldots$ & $\ldots$ & 5.8 & 5.3 & 4.8 & 2.9 & 2.7 \\
\hline Tourism & $\ldots$ & $\ldots$ & 26.7 & 28.3 & 27.0 & 34.9 & 34.2 \\
\hline Trade & $\ldots$ & $\ldots$ & 9.2 & 6.7 & 11.7 & 11.4 & 10.7 \\
\hline Transport & $\ldots$ & $\ldots$ & 0.5 & 0.3 & 0.6 & 2.5 & 2.5 \\
\hline Others & $\ldots$ & $\ldots$ & 11.1 & 13.5 & 12.7 & 10.4 & 12.0 \\
\hline Private households & $\ldots$ & $\ldots$ & 10.9 & 10.7 & 15.9 & 13.5 & 13.2 \\
\hline Mortgage loans & $\ldots$ & $\ldots$ & 17.2 & 14.1 & 12.9 & 9.7 & 9.2 \\
\hline Government & $\ldots$ & $\ldots$ & 0.5 & 0.1 & 0.5 & 0.1 & 0.0 \\
\hline \multicolumn{8}{|l|}{ Earnings and profitability } \\
\hline Net interest income/gross income & 47.9 & 47.7 & 50.7 & 73.4 & 43.8 & 32.3 & \\
\hline Net interest margin & 3.0 & 2.7 & 2.9 & 0.8 & 0.9 & 1.1 & 1.9 \\
\hline Net- non interest margin & -0.1 & 0.1 & 0.0 & -0.2 & -0.1 & 0.5 & 0.0 \\
\hline Non-interest efficiency & 92.9 & 105.5 & 99.4 & 65.2 & 78.7 & 167.2 & 194.3 \\
\hline Return on assets & 2.5 & 2.4 & 2.6 & 2.3 & 0.8 & 1.7 & 1.9 \\
\hline Return on equity & 51.0 & 46.8 & 47.1 & 39.3 & 11.3 & 23.2 & 24.3 \\
\hline Expense/income & 61.0 & 58.0 & 54.0 & 50.2 & 38.5 & 65.1 & 0.0 \\
\hline Interest rate spread (lending minus demand deposit rates) & 8.6 & 8.9 & 7.5 & 7.3 & $\ldots$ & $\ldots$ & 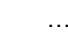 \\
\hline Gross claims on central government / total assets & 60.4 & 61.2 & 50.7 & 68.1 & $\ldots$ & $\ldots$ & $\ldots$ \\
\hline Liquid assets / total assets & 79.3 & 75.2 & 72.3 & 68.9 & 17.0 & 10.0 & \\
\hline Liquid assets / short term liabilities & 85.2 & 77.2 & 71.9 & 68.4 & 59.0 & 40.8 & 61.6 \\
\hline Loans / deposits & 21.2 & 25.4 & 29.7 & 32.0 & 27.5 & 31.7 & 27.6 \\
\hline Excess reserves / broad money & 3.0 & 3.7 & 3.1 & 3.4 & $\ldots$ & $\ldots$ & $\ldots$ \\
\hline Liquid assets / total deposits & 91.6 & 86.0 & 85.3 & 83.3 & 60.0 & 46.0 & $\ldots$ \\
\hline
\end{tabular}

Source: Bank Supervision Division, CBS. 
Table 8. Seychelles: Balance of Payments, 2007-18 (millions of U.S. dollars)

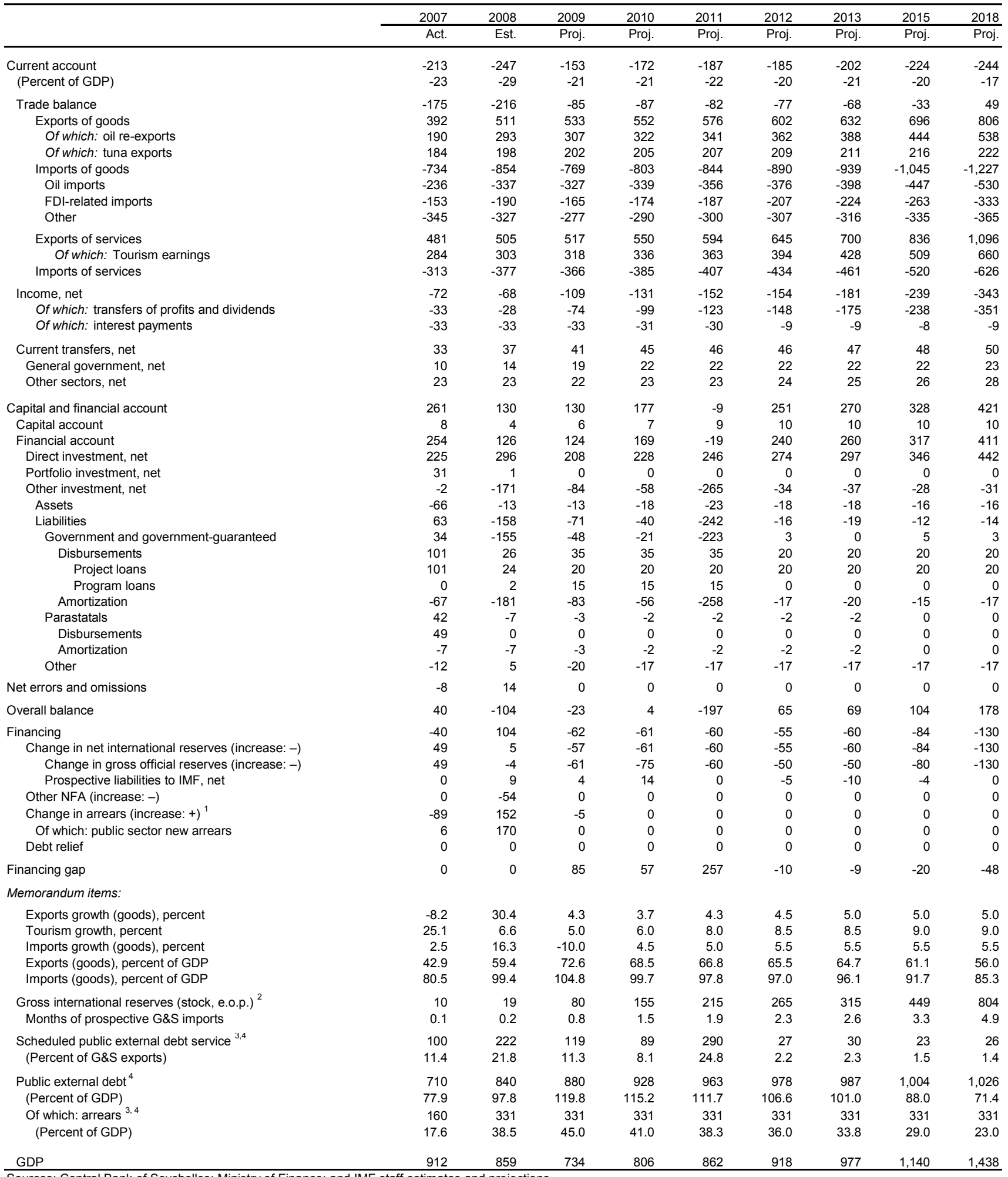

Sources: Central Bank of Seychelles; Ministry of Finance; and IMF staff estimates and projections.

${ }^{1}$ In 2008, includes accelerated promissory notes. In 2008-09, includes repayment of accrued investor profits.

${ }^{2}$ Starting with 2007, refers to CBS gross international reserves net of blocked deposits and project accounts.

${ }^{3}$ Debt service projections are based on exhisting stock of debt and identified new borrowing, assuming no debt restructuring and no repayment of arrears.

${ }^{4}$ Preliminary and subject to reconcilliation with creditors. 
Table 9. Seychelles: Fund Disbursements and Timing of Reviews Under the Prospective Two-Year Stand-By Arrangement, 2008-10

\begin{tabular}{|c|c|c|c|}
\hline \multirow[b]{2}{*}{ Date of availability } & \multirow[b]{2}{*}{ Conditions } & \multicolumn{2}{|c|}{ Amount } \\
\hline & & (millions of SDR) & (percent of quota) \\
\hline November 17, 2008 & Board approval of the SBA arrangement & 6.16 & 70 \\
\hline April 5, 2009 & $\begin{array}{l}\text { Completion of first review (end-December } 2008 \text { quantitative performance } \\
\text { criteria and relevant structural performance criteria) }\end{array}$ & 0.88 & 10 \\
\hline July 5, 2009 & $\begin{array}{l}\text { Completion of second review (end-March } 2009 \text { quantitative performance } \\
\text { criteria and relevant structural performance criteria) }\end{array}$ & 0.88 & 10 \\
\hline October 5, 2009 & $\begin{array}{l}\text { Completion of third review (end-June } 2009 \text { quantitative performance criteria } \\
\text { and relevant structural performance criteria) }\end{array}$ & 0.88 & 10 \\
\hline January 5, 2010 & $\begin{array}{l}\text { Completion of fourth review (end-September } 2009 \text { quantitative performance } \\
\text { criteria and relevant structural performance criteria) }\end{array}$ & 2.2 & 25 \\
\hline April 5, 2010 & $\begin{array}{l}\text { Completion of fifth review (end-December } 2009 \text { quantitative performance } \\
\text { criteria and relevant structural performance criteria) }\end{array}$ & 2.2 & 25 \\
\hline July 5, 2010 & $\begin{array}{l}\text { Completion of sixth review (end-March } 2010 \text { quantitative performance criteria } \\
\text { and relevant structural performance criteria) }\end{array}$ & 2.2 & 25 \\
\hline October 10, 2010 & $\begin{array}{l}\text { Completion of seventh review (end-June } 2010 \text { quantitative performance criteria } \\
\text { and relevant structural performance criteria) }\end{array}$ & 2.2 & 25 \\
\hline
\end{tabular}

Source: IMF staff estimates. 
Table 10. Seychelles: Projected Financing Requirements and Sources, 2008-18 (Millions of U.S. dollars)

\begin{tabular}{|c|c|c|c|c|c|c|c|c|}
\hline & 2008 & 2009 & 2010 & 2011 & 2012 & 2013 & 2015 & 2018 \\
\hline \multicolumn{9}{|l|}{ External Financing } \\
\hline Gross financing requirements & 302.5 & 324.4 & 328.4 & 530.2 & 277.4 & 296.3 & 341.3 & 413.3 \\
\hline External current account deficit (excl. official transfers) & 261.4 & 171.9 & 194.6 & 209.7 & 207.9 & 224.0 & 246.3 & 266.2 \\
\hline Amortization of public debt ${ }^{1}$ & 188.7 & 86.0 & 58.0 & 259.5 & 13.2 & 12.0 & 10.5 & 17.1 \\
\hline Change in arrears (repayment $=+$ ) & -151.7 & 5.0 & 0.0 & 0.0 & 0.0 & 0.0 & 0.0 & 0.0 \\
\hline Gross reserves accumulation (increase $=+$ ) & 4.0 & 61.0 & 75.0 & 60.0 & 50.0 & 50.0 & 80.0 & 130.0 \\
\hline IMF repurchases and charges & 0.0 & 0.4 & 0.8 & 1.0 & 6.3 & 10.3 & 4.4 & 0.0 \\
\hline Available financing & 302.4 & 239.6 & 271.6 & 273.7 & 287.1 & 305.5 & 360.8 & 460.9 \\
\hline Foreign direct investment & 295.9 & 208.5 & 227.5 & 246.4 & 274.3 & 297.0 & 345.8 & 441.6 \\
\hline Disbursements of program support ${ }^{2}$ & 1.6 & 15.0 & 15.0 & 15.0 & 0.0 & 0.0 & 0.0 & 0.0 \\
\hline Multilateral ${ }^{1}$ & 1.6 & 15.0 & 15.0 & 15.0 & 0.0 & 0.0 & 0.0 & 0.0 \\
\hline Bilateral & 0.0 & 0.0 & 0.0 & 0.0 & 0.0 & 0.0 & 0.0 & 0.0 \\
\hline Disbursements of project loans & 24.3 & 20.0 & 20.0 & 20.0 & 20.0 & 20.0 & 20.0 & 20.0 \\
\hline Possible debt relief & 0.0 & 0.0 & 0.0 & 0.0 & 0.0 & 0.0 & 0.0 & 0.0 \\
\hline IMF & 9.4 & 4.1 & 13.8 & 0.0 & 0.0 & 0.0 & 0.0 & 0.0 \\
\hline Other flows ${ }^{3}$ & -28.7 & -8.0 & -4.8 & -7.7 & -7.2 & -11.5 & -5.0 & -0.7 \\
\hline External financing gap & 0.0 & 84.8 & 56.8 & 256.5 & -9.7 & -9.2 & -19.5 & -47.6 \\
\hline \multicolumn{9}{|l|}{ Fiscal Financing } \\
\hline \multicolumn{9}{|l|}{ Gross fiscal requirements } \\
\hline Debt service & 260.4 & 173.8 & 119.5 & 309.9 & 34.3 & 36.6 & 34.4 & 46.1 \\
\hline Interest payments due & 71.6 & 87.8 & 61.5 & 50.4 & 21.1 & 24.6 & 23.9 & 29.0 \\
\hline Domestic & 38.8 & 54.8 & 31.9 & 20.1 & 12.3 & 15.8 & 15.5 & 19.9 \\
\hline External & 32.8 & 33.0 & 29.6 & 30.3 & 8.8 & 8.9 & 8.4 & 9.1 \\
\hline External principal repayments due ${ }^{1}$ & 188.7 & 86.0 & 58.0 & 259.5 & 13.2 & 12.0 & 10.5 & 17.1 \\
\hline Source of funds & 246.5 & 89.0 & 82.8 & 62.7 & 94.7 & 96.2 & 93.4 & 102.5 \\
\hline Primary balance & 61.1 & 44.4 & 53.0 & 58.3 & 53.5 & 54.0 & 48.1 & 51.7 \\
\hline Privatization and long-term leases & 27.9 & 28.2 & 6.2 & 6.3 & 6.4 & 6.6 & 7.0 & 7.7 \\
\hline Domestic (net) & -23.8 & -5.6 & -11.4 & -36.9 & 14.8 & 15.7 & 18.3 & 23.1 \\
\hline External disbursements & 25.8 & 35.0 & 35.0 & 35.0 & 20.0 & 20.0 & 20.0 & 20.0 \\
\hline Change in fiscal arrears (net) & 155.4 & -13.0 & 0.0 & 0.0 & 0.0 & 0.0 & 0.0 & 0.0 \\
\hline Fiscal financing gap ${ }^{4}$ & 13.9 & 84.8 & 36.6 & 247.2 & -60.3 & -59.6 & -59.0 & -56.4 \\
\hline
\end{tabular}

Sources: Central Bank of Seychelles; Ministry of Finance; and IMF staff estimates and projections.

${ }^{1}$ On existing debt and disbursements of new assumed debt, excluding IMF.

${ }^{2}$ Includes loans and grants.

${ }^{3}$ Includes all other net financial flows and errors and omissions.

${ }^{4}$ In 2008 , this also includes the statistical discrepancy and valuation changes. 
Table 11. Seychelles: Indicators of Fund Credit, 2007-18 (Millions of SDR)

\begin{tabular}{|c|c|c|c|c|c|c|c|c|c|}
\hline & 2007 & 2008 & 2009 & 2010 & 2011 & 2012 & 2013 & 2015 & 2018 \\
\hline \multicolumn{10}{|l|}{ Existing Fund credit } \\
\hline Stock $^{1}$ & 0.0 & 0.0 & 0.0 & 0.0 & 0.0 & 0.0 & 0.0 & 0.0 & 0.0 \\
\hline Obligation & 0.0 & 0.0 & 0.0 & 0.0 & 0.0 & 0.0 & 0.0 & 0.0 & 0.0 \\
\hline \multicolumn{10}{|l|}{ Proposed SBA } \\
\hline Disbursements & $\ldots$ & 5.9 & 2.6 & 8.8 & 0.0 & 0.0 & 0.0 & 0.0 & 0.0 \\
\hline Stock $^{1}$ & $\ldots$ & 6.2 & 8.8 & 17.6 & 17.6 & 14.2 & 8.1 & 0.0 & 0.0 \\
\hline Obligations $^{2}$ & $\ldots$ & 0.0 & 0.3 & 0.5 & 0.6 & 4.0 & 6.5 & 2.8 & 0.0 \\
\hline Principal (repayments/repurchases) & $\ldots$ & 0.0 & 0.0 & 0.0 & 0.0 & 3.4 & 6.1 & 2.8 & 0.0 \\
\hline Charges and interest & $\ldots$ & 0.0 & 0.3 & 0.5 & 0.6 & 0.6 & 0.4 & 0.1 & 0.0 \\
\hline Stock of existing and prospective Fund credit ${ }^{1}$ & 0.0 & 6.2 & 8.8 & 17.6 & 17.6 & 14.2 & 8.1 & 0.0 & 0.0 \\
\hline In percent of quota & 0.0 & 70.0 & 100.0 & 200.0 & 200.0 & 161.3 & 92.5 & 0.0 & 0.0 \\
\hline In percent of GDP & 0.0 & 1.1 & 1.9 & 3.4 & 3.2 & 2.4 & 1.3 & 0.0 & 0.0 \\
\hline In percent of exports of goods and services & 0.0 & 0.9 & 1.3 & 2.5 & 2.4 & 1.8 & 1.0 & 0.0 & 0.0 \\
\hline In percent of gross reserves & 0.0 & 51.5 & 17.3 & 17.9 & 12.9 & 8.5 & 4.1 & 0.0 & 0.0 \\
\hline \multicolumn{10}{|c|}{ Obligations to the Fund from existing and prospective } \\
\hline Fund arrangements & 0.0 & 0.0 & 0.3 & 0.5 & 0.6 & 4.0 & 6.5 & 2.8 & 0.0 \\
\hline In percent of quota & 0.0 & 0.3 & 3.0 & 5.7 & 7.3 & 45.6 & 73.8 & 31.8 & 0.0 \\
\hline In percent of GDP & 0.0 & 0.0 & 0.1 & 0.1 & 0.1 & 0.7 & 1.1 & 0.4 & 0.0 \\
\hline In percent of exports of goods and services & 0.0 & 0.0 & 0.0 & 0.1 & 0.1 & 0.5 & 0.8 & 0.3 & 0.0 \\
\hline In percent of gross reserves & 0.0 & 0.3 & 0.5 & 0.5 & 0.5 & 2.4 & 3.3 & 1.0 & 0.0 \\
\hline
\end{tabular}

Sources: IMF Finance Department; and IMF staff estimates and projections

${ }^{1}$ End of period

${ }^{2}$ Repayment schedule based on repurchase obligations. 


\section{APPENDIX \\ SEYCHELLES: LETTER OF INTENT}

October 31, 2008

Mr. Dominique Strauss-Kahn

Managing Director

International Monetary Fund

Dear Mr. Strauss-Kahn:

1. The government of Seychelles is determined to decisively address Seychelles' balance of payments and external debt crisis. Achievements in promoting high living standards and social development are in jeopardy. In 2006, the government initiated an economic reform program, but the global slowdown and sharp food and fuel price increases of 2007-08, have brought longstanding vulnerabilities to a head. In particular, pervasive foreign exchange restrictions and an overvalued pegged exchange rate are no longer tenable. These factors have led to acute foreign exchange shortages, an active parallel market, a sharp rise in inflation to over 30 percent, a depletion of our external reserves and external arrears accumulation. Following missed payments in July and October 2008 on our external commercial debt obligations Seychelles' external rating was downgraded to SD (selective default).

2. We are seeking the support of the International Monetary Fund and the international community more broadly for a strong and comprehensive program aimed at restoring external and internal economic balances. The program is described in the attached memorandum of economic and financial policies (MEFP) for 2008-09. This effort includes the removal of foreign exchange restrictions, a floating of the rupee, a significant fiscal and monetary tightening and the implementation of structural reforms to spur competitiveness and growth. At the same time, we have adopted a targeted social safety net that will help protect the most vulnerable segments of our population. We are preparing to initiate discussions with our external creditors with a view to reaching agreement on a restructuring of our external debt to close financing gaps and to restore public debt sustainability. In support of these important objectives, the Government of Seychelles hereby requests a two-year Stand-by arrangement in an amount of SDR 17.6 million (200 percent of quota).

3. We believe that the economic imbalances and dislocation we are experiencing reflect the need for a broad-based reform of the public sector and economic policies, which will require several years to implement with the sustained support of our partners. These reforms would entail, inter alia, a comprehensive review of the tax system and strengthening of tax administration, the downsizing of public sector employment, and reducing the role of the state in the economy, including further privatization of public 
enterprises. In this light, we will work with the IMF on developing a comprehensive structural reform program that would be implemented over the medium term. Once this work is finalized, we intend to request a longer-term engagement with the Fund under the Extended Fund Facility.

4. We believe that the economic and financial policies set forth in the MEFP are sufficient to ensure that the objectives of the 2008-09 program will be met. If needed, we stand ready to take any further measures that may prove necessary to meet our objectives. We will consult with the Managing Director on the adoption of such measures in advance of revisions to the policies contained in the MEFP, in accordance with the Fund's policies on such consultations. The Seychelles authorities will provide the Managing Director with all the information he may request in order to monitor program implementation and achieve program objectives on schedule.

5. The quarterly quantitative performance criteria and indicative targets for end2008 and 2009 are shown in Table 1. The structural performance criterion and benchmarks are shown in Table 2. The completion of the first review under the program will be based, inter alia, on meeting the performance criteria and structural benchmarks at end-December 2008. The first review will focus on progress in: the reform of the exchange regime; the use of market-based monetary policy; normalizing relations with external creditors; strengthening tax administration and public expenditure management; the preparation of a fundamental review of tax policy; strengthening the CBS act and operations to address areas identified by the safeguards assessment; and a 2009 budget consistent with program objectives.

6. In line with our commitment to transparency, we hereby authorize the IMF to publish this letter, the MEFP, the technical memorandum of understanding and the staff report. We will simultaneously publish these documents in Seychelles.

Sincerely yours,

/s/

James Alix Michel

President

Republic of Seychelles

Attachments:

Memorandum of Economic and Financial Policies

Technical Memorandum of Understanding 


\section{AtTACHMEnT I}

\section{Seychelles: Memorandum of Economic and Financial Policies For 2008-09}

\section{INTRODUCTION}

1. Over the past two decades Seychelles has successfully promoted high living standards and social development. In Africa, Seychelles has the second highest GDP per capita, is one of six upper-middle-income countries, and leads in human development. It is ranked 50th on the 2007 United Nations Development Program Human Development Index, a level comparable to many OECD countries.

2. Since the mid-1990s these achievements have been put increasingly at risk due to persistent macroeconomic imbalances, external shocks and long-standing structural problems. Large fiscal and parastatal deficits have led to rising external and domestic debt and a widening current account deficit. The state's dominance in the economy has further restrained the development of the private sector.

\section{Recognizing these challenges, in 2003 we began a reform and modernization} effort (the Macro-Economic Reform Program-MERP), which entailed a large fiscal adjustment and tax reform, as well as a gradual liberalization of the economy. By early 2007, achievements included a sizable depreciation of the rupee, partial exchange regime liberalization and the replacement of collateralized debt with part of the proceeds of a Eurobond issue. In March 2007, we announced our "Seychelles Strategy 2017", a broadbased 10-year reform strategy which aims at a doubling of nominal per-capita income in ten years and a reduction of public debt from 145 percent of GDP to 60 percent.

4. However, the pace of reform has been too gradual, piecemeal in nature, and insufficient to address the magnitude of the macroeconomic imbalances, so vulnerabilities remained high. The maintenance of a pegged exchange rate, which was not compatible with fiscal and monetary policy, together with pervasive foreign exchange restrictions has led to an overvaluation of the Seychelles rupee, a growing parallel market, and persistent foreign exchange shortages. This in turn has increasingly hampered competitiveness and economic growth. In 2007 we transformed a backlog of rupee deposits (totaling about 15 percent of 2007 GDP) awaiting conversion for transfer abroad into public external debt. In 2007-08, the global oil and food price shock hit the Seychelles economy particularly hard given its dependence on basic imports, with inflation rising sharply to 38 percent (year-on-year) by August 2008. Notwithstanding gradual adjustment of the exchange rate from 5 to 8 rupees to the US dollar between October 2006 and October 2007, the currency remained overvalued, exchange shortages persisted, and official external reserves were virtually exhausted. These imbalances came to a head in July 2008 when we missed a payment due on a privately-placed external debt issue. In October 2008, we were 
unable to make a coupon payment on our outstanding Eurobond. Standard and Poor's has downgraded Seychelles to SD (selective default).

5. The current situation calls both for immediate measures to remove the distortions in the foreign exchange market and restore external and fiscal sustainability, as well as comprehensive structural reforms to sustain growth and competitiveness. We have already taken measures in advance of commencing an IMF-supported program and have started laying the groundwork for future reforms. We will float the Seychelles rupee and have removed all exchange restrictions in order to restore confidence in our domestic currency. The change in exchange regime will be supported by a further significant tightening of fiscal and monetary policies, and we are putting in place a comprehensive debt restructuring strategy aimed at closing financing gaps and restoring debt sustainability. We are also preparing a comprehensive medium-term structural reform program that will remove existing distortions and obstacles to private sector development.

\section{RECENT DEVELOPMENTS}

6. Growth in 2008 has slowed considerably, under the combined impact of the global slowdown, the oil and food price shocks, and foreign exchange shortages. Real GDP growth is projected to be about 3.1 percent in 2008, down from 7.3 percent in 2007 . While construction is still booming, manufacturing activities are sharply declining and growth in a key indicator of tourism activity (visitors nights) has fallen to about 4.5 percent since early 2008 (year to date), from 16.6 percent for the same period in 2007. Inflation has accelerated sharply since mid-2007, driven by a weaker rupee, price liberalization, and the surge in international oil and food prices.

7. The 2008 budget has been implemented broadly as approved, delivering on the government's commitment to a significant tightening. The primary surplus is projected at 5.6 percent of GDP in 2008 (excluding a 1.5 percent of GDP transfer of valuation gains from the Central Bank) compared to a 2.3 percent deficit in 2007). More frequent adjustments toward cost-recovery levels for water and electricity prices are reducing government subsidies to the public utility company, and petroleum product prices are now adjusted monthly to reflect international prices. Despite inflationary pressures, primary spending has also been contained due to low public sector wage rises and tighter spending controls. Increased tax on fuel and a new import levy on automobiles have more than made up for a shortfall on goods and services tax (GST) due to the elimination of GST on 13 basic food items and cooking gas (LPG).

\section{The central bank (CBS) raised reserve requirements in response to rising} inflation. The reserve requirement on domestic currency deposits was increased from 5 to 13 percent as of June 1, 2008 and the same reserve requirement was introduced on foreign currency deposits in September. However, the local asset ratio (LAR-met only by holding domestic treasury obligations) was reduced from 65 to 50 percent, offsetting the increase in 
reserve requirements. Following the decision to remove excess reserves as part of the LAR computation, the LAR was reduced from 50 to 45 percent on September 15, 2008.

9. Based on mid-2008 data, commercial banks are adequately capitalized and have long net open positions in foreign exchange, but are vulnerable to interest rate and associated default risk. As of June 30, banking industry assets totaled about SR 8.8 billion (113 percent of GDP). Domestic lending accounted for only about 25 percent of assets with most funds invested abroad (34 percent), and domestic government securities accounted for 24 percent. Bank regulatory capital, measured on the most stringent capitalization measurenet tangible capitalization (i.e., capital net of all provisions for loan loss and intangibles) stood at 5.6 percent of net assets -40 basis points short of being considered well capitalized. However, banks' large position in treasury securities makes them vulnerable to declines in the values of those investments. Whereas industry capital as of June 30, 2008 covered about 22 percent of bank holdings of government securities, three banks had coverage of only 11 14 percent.

10. The external current account deficit is projected to reach 29 percent of GDP in 2008. The cost of transportation services imports is projected to increase by about

37 percent, while tourism earnings are being affected by the global slowdown, resulting in a significant deterioration of the services balance. The merchandise trade balance is, however, expected to improve somewhat, as the higher fuel and food import bill is largely offset by strong tuna exports and petroleum re-exports. As of end September official reserves had fallen to about US\$15 million, and the balance of payments is increasingly financed by external arrears accumulation.

11. At 151 percent of GDP (2008 figures), public debt is unsustainable. External public debt represents about two-thirds of the total (97.8 percent of GDP), of which 81 percent of GDP is in arrears. We have a small amount of arrears (US\$2.2 million at end-June 2008) to multilateral creditors. We have hired highly qualified financial and legal advisors to assist us in preparing a comprehensive debt strategy and engaging in good-faith discussions with our creditors.

\section{ECONOMic Program for 2008-09}

\section{The objectives of our reform program are to promote macroeconomic stability} and sustainable growth by:

- Achieving full convertibility of the Seychelles rupee and introducing a marketdetermined exchange rate regime;

- $\quad$ Placing public debt on a sustainable path by implementing a comprehensive debt restructuring strategy, coupled with further tightening of fiscal and monetary policy, while preserving financial sector stability; and 
- $\quad$ Reducing the role of the state in economic activity and enhancing the growthgenerating capacity of the private sector by creating conditions conducive private investment.

\section{The macroeconomic framework for the program period (2008-10) and the} medium-term is:

\begin{tabular}{|c|c|c|c|c|c|}
\hline \multicolumn{6}{|c|}{ Seychelles: Summary Table, 2006-2010 } \\
\hline & $\begin{array}{l}2006 \\
\text { Act. }\end{array}$ & $\begin{array}{r}2007 \\
\text { Est. }\end{array}$ & $\begin{array}{l}2008 \\
\text { Proj. }\end{array}$ & $\begin{array}{l}2009 \\
\text { Proj. }\end{array}$ & $\begin{array}{l}2010 \\
\text { Proj. }\end{array}$ \\
\hline \multicolumn{6}{|c|}{ (Annual percentage change) } \\
\hline Real GDP & 8.3 & 7.3 & 3.1 & -0.5 & 3.5 \\
\hline Consumer price index (average) & -1.4 & 5.7 & 32.2 & 33.8 & 12.6 \\
\hline \multicolumn{6}{|c|}{ (Percent of GDP) } \\
\hline Overall fiscal balance & -6.2 & -9.8 & -1.8 & -6.1 & -1.1 \\
\hline Primary balance & -0.6 & -2.3 & 7.1 & 6.2 & 6.6 \\
\hline Total public debt & 139.5 & 146.0 & 151.3 & 161.3 & 149.5 \\
\hline Domestic & 85.8 & 74.1 & 53.5 & 41.5 & 34.3 \\
\hline External & 53.7 & 71.9 & 97.8 & 119.8 & 115.2 \\
\hline Current account balance & -13.9 & -23.4 & -28.8 & -20.9 & -21.4 \\
\hline
\end{tabular}

- $\quad$ The program assumes a contraction in GDP in 2009 of about 0.5 percent, in part reflecting the recent deterioration of global economic conditions. A progressive recovery is projected in 2010 and beyond with average real GDP growth of about 5 percent, under the impulse of rising foreign investment in tourism following the lifting of exchange restrictions and other bottlenecks, which have hampered investment and growth.

- The real effective exchange rate is expected to depreciate sharply in late 2008 , with small and gradual real appreciation thereafter.

- $\quad$ Reflecting pass-through of the anticipated exchange rate depreciation, inflation would peak in the second quarter of 2009 at about 41 percent and gradually decline to 22 percent at end-2009.

- The current account balance is projected to improve significantly in 2009 , to a deficit of about 21 percent of GDP, and to remain at about that level through the medium term. Merchandise imports are expected to decline sharply (by about 10 percent in US dollar terms) in 2009 under the impact of the devaluation and a decline in FDI-related imports, before a gradual recovery broadly compatible with GDP growth in 2010 and beyond. The growth of goods exports is expected to be moderate at about 4 percent in 2009. Over the medium-term services exports, largely 
tourism, are expected to grow more strongly under the impulse of rising direct foreign investment, improved competitiveness, and the elimination of exchange restrictions.

- In the absence of external debt restructuring, public sector debt would increase to 169 percent of GDP in 2009, and remain at unsustainably high levels over the medium-term. Domestic debt would decline through a combination of fiscal restraint and negative real interest rates, particularly on long-term bonds. Debt servicing capacity is extremely limited in 2009-11 and highly dependent on the availability of program lending from multilaterals.

\section{A. Exchange Regime and Exchange Rate Policy}

14. We intend to reform fundamentally the exchange rate regime with a view to eliminate foreign exchange shortages, restore confidence in the Seychelles rupee as legal tender and enhance external competitiveness. In particular we are committed to removing all exchange restrictions and allowing the exchange rate of the rupee to be marketdetermined.

15. We believe that the current exchange rate peg is no longer viable, owing to the very low level of official foreign exchange reserves, limited external financing options, and large external debt obligations. We have taken the necessary preparatory steps to ensure that the exit from the peg is as orderly as possible (below). The following preparations have been completed as of end-October 2008.

- $\quad$ Amend the Central Bank (CBS) Act to repeal CBS determination of the exchange rate.

- $\quad$ Repeal Foreign Earnings (Regulations) Act, under which the extensive exchange controls were imposed.

- $\quad$ Remove requirements to pay in foreign exchange.

- $\quad$ Revoke requirements under the Exchange Control Act that (i) persons who are not authorized dealers must conduct foreign currency transactions (i.e., buying, selling, lending, or borrowing gold and foreign currency) with authorized dealers; (ii) persons authorized to buy foreign currency in the course of their business must sell such foreign currency to financial institutions (i.e., banks and exchange bureaus).

- $\quad$ Amend the Financial Institutions Act to authorize a new class of foreign exchange bureaus that may operate in accounts in addition to notes, coins, and travelers' cheques. 
In addition:

- We will prepare and submit to the National Assembly a modernized, simplified and transparent foreign exchange act by end-June 2009.

- With technical assistance from the IMF, we are establishing a platform at the Central Bank for interbank foreign exchange (FX) trading. While an augmented real-time gross settlement system should be introduced over the coming year, a manual bookentry system at the CBS will be used in the short term.

- We are reforming our monetary policy framework in order to conduct monetary policy based on reserve money targeting. Weekly auctions for 91-day treasury bills, and the establishment of a weekly auction for a central bank deposit facility (established in mid September) have already allowed for more efficient liquidity management and market-determined interest rates. The higher market-determined domestic interest rates observed in the run-up to the float will help contain possible exchange rate overshooting.

- We are working closely with commercial banks to ensure that they promptly establish internal rules for FX trading and risk management based on international best practices.

\section{B. Debt Restructuring Strategy}

\section{The success of our adjustment and reform program requires external financial} support, including a restructuring of our external debt. We are committed to sustaining a strong fiscal effort over the medium term. However, no plausible fiscal adjustment can deliver-on its own-funds sufficient to close our near term financing gaps and return our future debt service payments to sustainable levels. On September 30, 2008, we publicly announced that we would seek to restructure about US\$800 million of external debt, and requested the support of our creditors. With the assistance of our legal and financial advisors, we are committed to developing a comprehensive debt restructuring strategy, consistent with the Fund's lending into arrears policy, with particular focus on information transparency, intercreditor equity, and dialogue with all creditor groups. We will seek a restructuring of our external liabilities aimed at restoring public debt sustainability, and consistent with our ability to pay. Immediate and sizable cash flow relief in the short- to medium-term, sustained reduction of our debt service burden, and significant balance of payments support from our international partners, will be necessary. With regard to domestic debt, we will need to assure the stability of our banking system which has a large portion of its assets in government debt. We have approached multilateral creditors with whom we have arrears seeking agreement on an arrears clearance strategy.

\section{Strengthening public debt management forms an integral part of our adjustment} strategy. We will submit to the National Assembly a Public Debt Law, defining a legal framework for public debt management, and specifying the roles and responsibilities of the bodies engaged in contracting and managing public debt by end-December 2008. As agreed with IMF staff, we will formulate a medium-term public debt strategy, aimed at achieving an 
optimal trade-off between cost and risk of public debt and consistent with long-run debt sustainability. We will increase transparency of public debt management by publishing quarterly and annual reports on the implementation of the debt strategy. We also plan to strengthen the rules governing provision of government guarantees and start charging guarantee fees. We would welcome technical assistance in these areas from the IMF's Monetary and Capital Markets Department. As part of our strategy, we also commit to refrain from contracting or guaranteeing new loans outside of the limits set-out in the program, including project financing, and we will not accumulate new arrears to external or domestic creditors.

\section{Fiscal Policy}

18. The further consolidation of public finances is central to the program. We are committed to implementing a large and sustained fiscal adjustment that will help both anchor the move to a floating exchange rate regime and allow for a gradual reduction in public debt. Primary surpluses of about 6.5 percent of GDP will be maintained in 2009-10, easing gradually over the medium term. These objectives will be achieved through a combination of expenditure restraint, including the elimination of subsidies and a reduction of the wage bill in real terms (from about 9.1 percent of GDP in 2008 to 6.4 percent of GDP in 2010) as part of our plan to reduce the size of the public sector, tax policy measures including the removal of exemptions, strengthened tax administration and public financial management, public sector reform, and further privatization of public enterprises.

\section{Fiscal measures}

19. We are committed to taking urgent measures to reinforce fiscal revenue. We will apply the goods and services tax (GST) to all locally-manufactured and imported goods, except for 13 basic food items, and remove discretionary powers to grant exemptions. The following revenue measures will be introduced in the fourth quarter of 2008 according to the schedule below:

\begin{tabular}{|l|l|}
\hline \multicolumn{1}{|c|}{ Action } & \multicolumn{1}{|c|}{ Timing } \\
\hline $\begin{array}{l}\text { Raise and harmonize taxes on locally-produced and imported cigarettes } \\
\text { to SR500 per 200 cigarettes. }\end{array}$ & October 1, 2008 \\
\hline Introduce 10 percent withholding tax on interest income for residents. & October 1, 2008 \\
\hline Extend GST to all telecom companies. & October 1, 2008 \\
\hline $\begin{array}{l}\text { Announce the introduction of the GST of 15 percent on residential rental } \\
\text { income, effective January 1, 2009. }\end{array}$ & October 10, 2008 \\
\hline $\begin{array}{l}\text { Announce the removal of the exemption on interest income by } \\
\text { companies (Tax Act) effective January 1, 2009. }\end{array}$ & November 1, 2008 \\
\hline Reintroduce GST on locally produced soft drinks. & November 1, 2008. \\
\hline Raise GST on tourism services from 7 percent to 10 percent. & November 1, 2008 \\
\hline $\begin{array}{l}\text { Raise specific taxes/excise tax rates for both locally manufactured and } \\
\text { imported alcohol to adjust for inflation. }\end{array}$ & November 1,2008 \\
\hline
\end{tabular}


and as part of the 2009 budget, we will introduce the following revenue measures:

\begin{tabular}{|l|l|}
\hline \multicolumn{1}{|c|}{ Action } & \multicolumn{1}{|c|}{ Timing } \\
\hline Raise environmental levy to SR25 from SR10 per month per household. & January 1, 2009 \\
\hline Adjust fees, fines, charges and rents and royalties for inflation. & January 1, 2009 \\
\hline Reinstate GST on LPG. & January 1, 2009 \\
\hline Raise GST on tourism services from 10 percent to 12 percent. & November 1, 2009 \\
\hline $\begin{array}{l}\text { Repeal all provisions for discretionary exemptions in the Trade Tax and } \\
\text { Business Tax Acts }\end{array}$ & January 1, 2009 \\
\hline
\end{tabular}

20. We are committed to replacing costly and inefficient direct and indirect product subsidies with a well-targeted social safety net. Over the past 20 years, the Seychelles' government has provided a generous and broad-based social safety net. Now, as the economy undergoes structural reforms to restore competitiveness, we are in the process of finalizing a review of the welfare system. The primary aim of this review is to adopt a multi-dimensional approach to the question of welfare support. This approach will aim at protecting the most vulnerable segments of our population that have been hard hit by the rise in inflation, particularly increased food prices. But the new safety net will go beyond monetary transfers, which in some instances can be a disincentive for people to seek employment: while providing assistance in a quick and effective way (applicants will receive a response within 3 days), it will also establish a means-testing system, and include an explicit exit strategy. The agency responsible for implementing the new welfare legislation will be operational by November 1, 2008, and will be funded out of the budget. The specific subsidies being eliminated include:

\begin{tabular}{|l|l|}
\hline \multicolumn{1}{|c|}{ Action } & \multicolumn{1}{c|}{ Timing } \\
\hline Abolish fishermen fuel subsidy coupons. & October 1, 2008 \\
\hline $\begin{array}{l}\text { Eliminate indirect universal product subsidies and replace with a } \\
\text { targeted social safety net by enacting the Welfare Agency Act. }\end{array}$ & November 1, 2008 \\
\hline Eliminate SR90 per month electricity rebate for households. & January 1, 2009 \\
\hline $\begin{array}{l}\text { Raise and maintain Seychelles Public Transportation Company (SPTC) } \\
\text { bus fare at operating cost-recovery levels. }\end{array}$ & January 1, 2009 \\
\hline $\begin{array}{l}\text { Eliminate implicit and explicit subsidies for Agro Industries, } \\
\text { Hatcheries, Seychelles Trading Company (STC), and Coevity Prawns. }\end{array}$ & January 1, 2009 \\
\hline $\begin{array}{l}\text { Eliminate LPG subsidy by the state oil company (SEPEC) (about SR3 } \\
\text { per kg.). }\end{array}$ & January 1,2009 \\
\hline
\end{tabular}

\section{These changes are additional to the expenditure measures that have already}

been taken, including the implementation in 2008 of a hiring freeze for the public sector; the establishment of a public enterprise monitoring unit in the Ministry of Finance to reinforce parastatal performance monitoring, reporting, better assess quasi-fiscal risks, and the enforcement of a full cost recovery policy in the provision of public utilities. 


\section{Fiscal structural reforms}

22. Strengthening the public financial management framework and the budgetary process should underpin and facilitate fiscal consolidation. We will strengthen the budget formulation and execution process to ensure that resources can be allocated and used efficiently and that established spending limits are respected. In particular, an IMF mission recently conducted a public financial management review, and we commit ourselves to implementing its recommendations. In particular, we are reviewing options for expenditure rationalization as suggested in the report, including outsourcing non-core activities (see below), and plan to strengthen the budget preparation, implementation and monitoring processes, including through the preparation of a consistent medium-term macroeconomic framework.

23. A high-level government task force, headed by the Minister of Finance, is laying the groundwork for major public service reform. The task force is conducting a comprehensive review of the range of services provided by the government, with a view to eliminating duplication and to outsourcing services that can be provided more efficiently by the private sector. We believe public sector employment has become bloated and given continued strong demand for labor from the private sector, there is considerable scope for public sector employment rationalization. We intend to reduce the number of government employees by 12.5 percent in 2009 through a voluntary and involuntary departure scheme. A separation package is expected to provide sufficient time and means for former public employees to be retrained and employed in the private sector. A voluntary scheme will be conducted in October/November 2008, which would be followed by involuntary redundancies in the event that the voluntary scheme does not achieve the targeted employment reductions, with the departures scheduled to take place by January 1, 2009.

\section{We are convinced that a fundamental review of the tax system is urgently}

needed. The current system has many differentiated rates of tax, high overall tax rates for businesses, and a significant number of exemptions, particularly for foreign investors. Our objective is to have a simple, fair, and equitable system, featuring low, harmonized rates and a broader tax base, which will reduce incentives for evasion. Such a fundamental review needs to be well prepared, and we have requested technical assistance from the IMF's fiscal affairs department.

25. Strengthened tax administration and improved governance are key in enhancing confidence that the tax system is fair and equitable. As an immediate step the Seychelles Revenue Commission has launched tax audits of the 20 largest enterprises (by turnover), in the tourism, banking, construction, and fishing sectors, to be completed by end-June 2009 . We are also strengthening tax administration and reinforcing efforts to recover unpaid taxes. We have requested technical assistance on tax administration from the IMF's fiscal affairs department. 
26. We are actively pursuing the further privatization of public enterprises, with a view to encouraging private sector activity. Parastatals are costly to the budget due to extensive direct and indirect subsidies, and some are involved in activities that can be more efficiently provided by the private sector. Our privatization program will continue over the next year with the divestiture of the Seychelles Savings Bank, the Agro Industries, the Animal Feed Factory and the Coetivy Prawn Farm. Going forward we intend to avoid retaining minority stakes in the firms we privatize. In March 2008 we created a government agency (Societé Seychelloise d'Investissement; SSI ) to strengthen the monitoring of firms in which the government has a significant stake. In addition to the tax audits of the largest firms, the SSI will commission management audits of firms with large state holdings, including of the tuna cannery plant.

\section{Monetary Policy}

27. Monetary policy will play an important role in seeking to establish price stability, with greater emphasis on liquidity management. The CBS will rely more actively on market-based monetary policy instruments to achieve price stability following the shift to a flexible exchange rate. The exchange rate anchor will be replaced by a reserve money target, and indirect, market-based monetary policy instruments are being developed to allow the CBS to manage liquidity actively. As part of the new monetary policy, domestic interest rates have already increased and are likely to rise further, especially in the period around the floating of the rupee. The introduction of facilities for trading T-bills, foreign exchange and deposits at the central bank will promote more efficient liquidity management by commercial banks and support the development of an active inter-bank market. The new framework will create a healthier financial environment by improving efficiency and competition in the financial sector. The CBS and the government are committed to providing a regular and predictable supply of instruments over a range of maturities to facilitate market development and the establishment of a market-based yield curve.

28. The CBS is committed to eliminating distortions in the financial market over the program period. Burdensome financial regulations underpinning the current system of administrative monetary policy instruments will be streamlined and gradually phased out. In particular:

- $\quad$ The LAR will be phased out over the program period as conditions permit, in consultation with IMF staff, so as to promote lending to the private sector. It will be replaced by a supervisory liquidity requirement for prudential purposes, and financial supervision will be strengthened.

- $\quad$ Statutory commercial bank reserves will be remunerated at $0.25 \%$ per annum. However, excess reserves are no longer remunerated and no longer form part of the LAR.

- $\quad$ The CBS introduced weekly auctions for a liquidity deposit facility on September 22, 2008. Initially, deposits will be auctioned for 7, 14 and 28 days in amounts which will be determined by liquidity sterilization objectives. 
- $\quad$ The CBS is also providing a facility for the trading of government securities at market rates of discount. Weekly auctions of 91-day T-bills started October 3, 2008.

29. The CBS continues to need international support to build capacity for policy monitoring and implementation. We have benefited from IMF technical assistance in central banking, foreign exchange markets and banking supervision. We welcome expert visits from the IMF's Monetary and Capital Market Department to continue to assist us in: establishing an interbank market in foreign exchange, government securities, and bank deposits with the CBS; initiating automation of this market; introducing a monetary framework based on reserve money targeting; and reinforcing banking supervision. Furthermore, we have requested a long-term monetary advisor to help us deal with the transition from a fixed to floating exchange rate regime.

30. The CBS is committed to addressing areas identified by the IMF safeguards assessment mission of September 2008. We have already invited international audit firms to tender for the external audit of the 2008 accounts. For the 2008 and future audits, we also commit to appointing only international audit firms with recognized experience in central bank audits. The 2008 audit requirements will be further formalized by developing a Supplementary Statement of Work, specifying, inter alia: (i) an audit partner with recognized experience in central bank audits, (ii) full compliance with International Standards on Auditing, and (iii) that quarterly audits of key monetary data, as specified in the TMU, will be conducted in addition to the financial statements audit. The data will be submitted to the IMF in conformity with the program quarterly quantitative performance criteria throughout the program period, beginning with December 2008 data. With IMF assistance, we also intend to strengthen the governance and transparency aspects of the CBS Act and CBS operations in 2008-2009, in line with the recommendations of the safeguards assessment and previous IMF recommendations in 2008-09. As a first step, we will address the current lack of formal procedures for CBS's transactions on behalf of government, in particular:

\begin{tabular}{l|c|}
\multicolumn{1}{|c|}{ Action } & Timing \\
\hline $\begin{array}{l}\text { Approve a memorandum of understanding, under Article 34 of the CBS act, } \\
\text { formalizing the operational terms and conditions under which the CBS acts } \\
\text { as agent for the government. }\end{array}$ & End-December 2008 \\
\hline
\end{tabular}

\section{E. Financial Sector Stability}

31. We are fully aware that the envisaged changes in the exchange rate regime and monetary policy framework will, against the background of global financial turbulence, pose challenges to the stability of the financial sector in the short run. Based on tighter credit quality standards, and given that mid-2008 data showed strong net open positions in foreign currencies, a depreciation of the Seychelles rupee would improve the capital position of most banks. However, these foreign exchange positions can change quickly and we will closely monitor them. Another concern is the impact of higher interest rates on default rates 
by borrowers. Government-owned financial institutions would also be affected both by exchange rate as well as interest rate risk.

32. We are committed to carefully monitoring the impact of the exchange rate regime change on banks and non-banks' balance sheet, and to taking all measures necessary to maintain the stability and soundness of the financial system. In this light, the government has provisioned a contingency in the 2009 budget to cover for potential losses and recapitalization needs of the state-owned financial institutions. A reassessment of the strategic role of public non-bank financial institutions will also be undertaken, and we are seeking technical assistance to create a specialized oversight function at the Ministry of Finance and advise on options available to the government.

\section{F. Transparency and Good Governance}

33. Private investment is a key component of our country's sustained economic growth over the medium-term, and we shall take the necessary steps to ensure that all potential investors are treated with equity and with the highest level of transparency. This will entail the revamping of the process by which new direct investment is attracted to remove discretionary incentives and ensure a level playing field. The authority for approving new projects will be centralized at the Ministry of Finance, with the final approval resting with the cabinet. We will ensure that the investment code is uniformly applied, and that all discretionary ministerial exemptions are removed.

34. We are committed to enforce the highest standards of transparency and accountability in the public and private sectors. In August 2008 we adopted the Public Officers Ethics Act, which provides for a code of conduct and ethics for civil servants, requiring financial declarations and prohibiting conflicts of interest. The Public Procurement Act, modeled on the COMESA standard, will be passed by December 2008. The objective of the act is to standardize procurement procedures within the government by modernizing and harmonizing regulations and procedures. Transparency, competitiveness, and efficiency will be enhanced as tender procedures will ensure competitive bidding through strict and uniform requirements regarding minimum number of bidders and public disclosure of all bids. In July 2008, we amended the Anti-Money Laundering (AML) Act to establish a Financial Intelligence Unit with powers of investigation and sanction, and to strengthen the proper enforcement of AML regulations by enabling the Supreme Court to order civil proceedings for the preservation and disposal of proceeds of criminal conduct under the Act.

\section{G. Statistical Issues}

35. In spite of significant improvements, we recognize that there remain deficiencies in key macroeconomic data - especially deflator estimates, and foreign trade statistics, which limit their usefulness for surveillance, economic analysis, and policy formulation. The government will further strive to improve the quality, periodicity, and timeliness of macroeconomic statistics. The government will request technical assistance in these areas 
from the Statistics Department of the Fund. We will also strive to implement the GFS classification in order to present our fiscal accounts in the IMF format for easier budget monitoring and reporting.

\section{H. Program financing}

36. For 2008, the program is financed, after disbursement of US\$1.6 million in financial assistance from the European Union and of the first tranche of the prospective SBA of 70 percent of quota (SDR 6.16 million) from the IMF. For 2009, the external nonproject financing requirement is expected to be covered by disbursements from the IMF under the prospective SBA (30 percent of quota; SDR 2.64 million; US\$3.85 million), from multilateral creditors (US\$15 million) and from external debt relief (US\$85million).

\section{Program Monitoring}

\section{The SBA will be monitored by quarterly program and financing assurances}

reviews. The quarterly quantitative performance criteria and indicative targets for end-2008 and 2009 are shown in Table 1. The structural benchmarks and performance criterion for the first review are shown in Table 2. The non zero ceilings on the contracting or guaranteeing of external debt are to allow for nomal public project finance and program support from multilateral institutions exclusively.

38. The completion of the first review under the program will be based on meeting the quantitative performance criteria at end-December 2008. It will focus on progress in: the reform of the exchange regime; the use of market-based monetary policy, normalizing relations with external creditors; the preparation of a fundamental review of tax policy; the strengthening of tax administration and public expenditure management; strengthening the CBS act and operations to address areas identified by the safeguards assessment; and a 2009 budget consistent with program objectives. The first program and financing assurances review under the Stand-by arrangement is scheduled to be completed in early April 2009, and the second program and financing assurances review should be completed in early July 2009. The attached Technical Memorandum of Understanding (TMU) defines the quantitative performance criteria, indicative targets and adjusters under the program. Seychelles will avoid introducing new exchange restrictions, multiple currency practices, or bilateral payments agreements in contradiction with Article VIII of the IMF's Articles of Agreement and imposing any import restrictions for balance of payments reasons. The authorities stand ready to adopt any additional measures, in consultation with Fund staff, which may become necessary to ensure program success. 
Table 1. Seychelles: Quantitative Performance Criteria Under the Stand-By Arrangement, 2008-09

(Millions of Seychelles rupees; end-period data)

\begin{tabular}{|c|c|c|c|c|c|c|c|}
\hline & \multicolumn{3}{|c|}{2008} & \multicolumn{4}{|c|}{$2009^{1}$} \\
\hline & $\begin{array}{l}\text { June } \\
\text { Act }\end{array}$ & $\begin{array}{c}\text { Sept } \\
\text { Est }\end{array}$ & Dec. & Mar. & Jun. & Indicative & Dec. \\
\hline \multicolumn{8}{|l|}{$\overline{\text { Performance criteria }^{1}}$} \\
\hline Net international reserves of the CBS, in millions of US dollars (floor) ${ }^{2}$ & 14 & 14 & 19 & 20 & 18 & 57 & 80 \\
\hline Reseve money (ceiling) & 1282 & 1271 & 1151 & 1146 & 1261 & 1393 & 1386 \\
\hline Primary balance of the consolidated government (cumulative floor) ${ }^{3,4}$ & 229 & 420 & 560 & 73 & 88 & 299 & 622 \\
\hline The contracting or guaranteeing of new external debt by the public sector (in millions of US dollars; cumulative ceiling) ${ }^{3}$ & & & 15 & 10 & 10 & 30 & 35 \\
\hline \multicolumn{8}{|l|}{ subceiling: } \\
\hline The contracting or guaranteeing of new short-term external debt by the public sector (in millions of US dollars; cumulative ceiling) ${ }^{3}$ & & & 0 & 0 & 0 & 0 & 0 \\
\hline The accumulation of external payments arrears by the public sector (ceiling) ${ }^{5}$ & & & 0 & 0 & 0 & 0 & 0 \\
\hline The accumulation of domestic payment arrears by the public sector (ceiling) & & & 0 & 0 & 0 & 0 & 0 \\
\hline \multicolumn{8}{|l|}{ Memorandum items } \\
\hline External non project financing (in millions of US dollars; cumulative) ${ }^{3}$ & & & 0 & -10 & -23 & -11 & -19 \\
\hline Program financing support ${ }^{3}$ & & & 2 & 0 & 0 & 15 & 15 \\
\hline Cash payments on foreign debt service ${ }^{3}$ & & & 2 & 10 & 23 & 26 & 34 \\
\hline Program accounting exchange rates & 8.00 & 8.00 & 14.00 & 14.00 & 14.00 & 14.00 & 14.00 \\
\hline SR/USD (end-of-quarter) & 1.58 & 1.46 & & & & & \\
\hline USD/Euro (end of quarter) & 1.99 & 1.84 & & & & & \\
\hline USD/UK pound (end of quarter) & 1.63 & 1.56 & & & & & \\
\hline \multicolumn{8}{|l|}{ USD/SDR (end of quarter) } \\
\hline Reserve requirement (percent of deposits) & 13 & 13 & 13 & 13 & 13 & 13 & 13 \\
\hline Local asset ratio (percent of deposits) & 50 & 45 & 45 & 45 & 45 & 45 & 45 \\
\hline
\end{tabular}

Sources: Seychelles authorities and Fund staff estimates and projections.

${ }^{1}$ Targets for June, September and December 2009 are indicative.

${ }^{2}$ The floor will be adjusted downwards (upwards) for any shorffall (excess) in external non-project financial support from that assumed in the program.

${ }_{3}^{3}$ Cumulative flows from the beginning of the callendar year.

${ }^{4}$ The floor will be adjusted upwards for any unused amounts of the contingency in the budget for the recapitalization of the banking sector assumed in the program. Amounts of the contingency in excess

of programmed amounts need to be funded within the program limits.

${ }^{5}$ The non-accumulation of new external payment arrears constitutes a continous performance criterion. Excludes arrears for which a rescheduling agreement is sought. 
Table 2. Seychelles-Structural Benchmarks and Performance Criterion, 2008-June 2009

Measure

Target date

Status

\section{Structural performance criterion}

- Complete tax audits by Seychelles Revenue Commission of

end-June 2009 the 20 largest companies (paragraph 25).

\section{Structural benchmarks}

- Submit to parliament a Public Debt Law, defining a legal

end-December 2008 framework for public debt management, and specifying the roles and responsibilities of the bodies engaged in contracting and managing public debt (paragraph 17).

- Parliamentary approval of a Public Procurement Act end-December 2008 (paragraph 34).

- Approve a memorandum of understanding, under Article 34 of

end-December 2008 the CBS act, formalizing the operational terms and conditions under which the CBS acts as agent for the government. (paragraph 30) 


\section{ATtACHMENT II}

\section{SEYCHELLES: TECHNICAL MEMORANDUM OF UNDERSTANDING}

1. This technical memorandum of understanding presents the definitions of variables included in the quantitative performance criteria and indicative targets set out in the memorandum of economic and financial policies (MEFP), the key assumptions, and the reporting requirements of the Government and the Central Bank of Seychelles (CBS) needed to adequately monitor economic and financial developments. The quantitative performance criteria and indicative targets, and the structural performance criterion and benchmarks for 2008-09 are listed in Tables 1 and 2 of the MEFP, respectively.

\section{QUANTITATIVE PERFORMANCE CRITERIA}

\section{A. Net International Reserves of the CBS (floor)}

\section{Definition}

2. Net international reserves (NIR) of the CBS are defined for program monitoring purposes as reserve assets of the CBS, minus reserve liabilities of the CBS (including liabilities to the IMF). Reserve assets of the CBS are claims on nonresidents that are readily available (i.e., liquid and marketable and free of any pledges or encumberments and excluding project balances held in CBS accounts), controlled by the CBS, and held for the purpose of intervening in foreign exchange markets. They include holdings of SDRs, holdings of foreign exchange, demand and short-term deposits at foreign banks abroad, fixed-term deposits abroad that can be liquidated without penalty, and any holdings of investment-grade securities. Reserve liabilities of the CBS comprise liabilities to nonresidents contracted by the CBS, any net off-balance-sheet position of the CBS (futures, forwards, swaps, or options) with either residents or nonresidents, including those to the IMF.

Net International Reserves of the CBS

(as of October 13, 2008)

\begin{tabular}{lc}
\hline & (in millions of U.S. dollars) \\
Net foreign assets of the CBS & 92.7 \\
Foreign assets & 14.6 \\
Official reserves (A) & 14.6 \\
Other claims & 0 \\
Foreign liabilities & 0 \\
Liabilities vis-à-vis correspondents (excluding IMF) & 0 \\
Liabilities to the IMF (B) & 0 \\
Other liabilities & 0 \\
Net International Reserves (A-B) & 14.6 \\
\hline
\end{tabular}




\section{Calculation method}

3. For program monitoring purposes, reserves assets and liabilities at each test date, must be converted into U.S. dollars using the end of period exchange rates assumed in the program.

\section{Monitoring and reporting}

4. At each program test date, the quarterly net international reserves data submitted by the CBS to the IMF will be audited by the CBS external auditors in accordance with International Standards on Auditing, to ensure conformity with the program definition and calculation methods. Reports should be submitted to the CBS, with a copy to the IMF, no later than two months after each test date.

\section{Adjusters}

5. The floor on the CBS's NIR will be adjusted upward (downward) by the amount by which the new external balance of payments financing exceeds (falls short of) the amounts assumed in the program (MEFP Table 1). The floors will also be adjusted upwards (downwards) by the amount that external debt service payments fall short (exceed) the amounts assumed in the program.

\section{B. Reserve Money (Ceiling)}

\section{Definition}

6. Reserve money is equivalent to currency issued and deposits held by financial institutions at the central bank (bank reserves). Evaluation of performance of reserve money with respect to the program ceiling will take account of any changes in regulations affecting the level of banks' required reserves.

\section{Monitoring and reporting}

7. For each program test date, the quarterly reserve money data submitted by the CBS to the IMF will be audited by the CBS' external auditors in accordance with International Standards on Auditing, to ensure conformity with the program definition. Reports should be submitted to the CBS, with a copy to the IMF, no later than two months after each test date.

\section{Adjusters}

8. The reserve money target would be lowered (raised) for any reduction (increase) in the reserve requirements from those assumed in the program. A change in the reserve requirement coefficient will change the reserve money (RM) ceilings according to the following formula: 


$$
\Delta \mathrm{RM}=\Delta \mathrm{r}_{\mathrm{D}} * \mathrm{DD}_{0}+\Delta \mathrm{r}_{\mathrm{F}} * \mathrm{DF}_{0}
$$

where: $\mathrm{DD}_{0}$ denotes the level of domestic currency deposits and $\mathrm{DF}_{0}$ denotes the level of foreign currency deposits to which the reserve requirements for domestic currency and foreign currency deposits, respectively, apply during the period immediately preceding the date when the new reserve regulation becomes effective; $\Delta r_{D}$ and $\Delta r_{F}$ denote the change in the reserve requirement coefficient for domestic currency and foreign currency deposits, respectively.

\section{Primary balance of the consolidated government (cumulative floor)}

9. The consolidated government primary balance from above the line on a commitment basis is defined as total consolidated government and social security fund revenues (excluding privatization and long-term lease income receipts) less all noninterest (primary) expenditures of the government and social security fund.

\section{Adjusters}

10. The floor on the primary surplus of the consolidated government will be adjusted upwards by the cumulative amount of the contingency for recapitalizing the state-controlled financial institutions which is not used for that purpose. Any amounts spent for the recapitalizing of the state-controlled financial institutions in excess of programmed contingency will need to be funded within the program limit on the primary balance.

\section{Public External Debt (ceiling)}

11. The ceiling applies to the contracting or guaranteeing of new external liabilities by the public sector (including the central government, the CBS, and all public agencies and parastatals for operations that are not directly linked to commercial activities). The ceiling does not apply to the use of Fund resources, operations related to external debt restructuring; normal import related credits; purchases of treasury securities by non-residents; or borrowing by parastatals in the conduct of normal commercial operations. The non zero ceilings on the contracting or guaranteeing of external debt are to allow for nomal public project finance and program support from multilateral institutions exclusively. Debt shall be valued in U.S. dollars at program exchange rates.

- A zero subceiling on short-term external debt applies continuously to the contracting or guaranteeing of short-term external debt by the public sector, with an original maturity of up to and including one year. .

12. For the purpose of this performance criterion, the term "debt" has the meaning set forth in point No. 9 of the Executive Board's Guidelines on Performance Criteria with Respect to Foreign Debt (Decision No. 12274-(00/85)). Debt is understood to mean a current, non contingent liability, created under a contractual arrangement through the provision of value in the form of assets (including currency) or services, and which requires the obligor to make one or more payments in the form of assets (including currency) or services, at some future points in time; these payments will discharge the principal and/or interest liabilities 
incurred under the contract. The ceiling on contracting official and officially guaranteed external debt includes all form of debt, including:

(i) loans, i.e., advances of money to the obligor by the lender made on the basis of an undertaking that the obligor will repay the funds in the future (including deposits, bonds, debentures, commercial loans, and buyers credits) and temporary exchanges of assets that are equivalent to fully collateralized loans under which the obligor is required to repay the funds, and usually pay interest, by repurchasing the collateral from the buyer in the future (such as repurchase agreements and official swap arrangements);

(ii) suppliers credits, i.e., contracts where the supplier permits the obligor to defer payments until some time after the date on which the goods are delivered or services are provided; and,

(iii) leases, i.e., arrangements under which property is provided which the lessee has the right to use for one or more specified period(s) of time that are usually shorter than the total expected service life of the property, while the leasor retains title to the property. The debt is the present value (at the inception of the lease) of all lease payments expected to be made during the period of the agreement excluding those payments that cover the operation, repair, or maintenance of the property.

Arrears, penalties, and judicially awarded damages arising from the failure to make payment under a contractual obligation that constitutes debt are debt.

\section{E. External arrears of the public sector}

13. The non-accumulation of arrears to external creditors will be a continuous performance criterion under the program. External payments arrears for program monitoring purposes are defined as the amount of external debt service due and not paid within the contractually agreed period, including contractual and late interest. Arrears resulting from the nonpayment of debt service for which a clearance framework has been agreed or a rescheduling agreement is sought are excluded from this definition.

\section{F. Budget expenditure arrears}

14. The non-accumulation of budget expenditure arrears will be a continuous performance criterion under the program. Budget expenditure arrears are defined as the sum of (1) any invoice that has been received by a spending agency from a supplier of goods, services, and capital goods delivered and verified, and for which payment has not been made within the contractually agreed period, or in the absence of a grace period, within 30 days; (2) unpaid wages, pensions, or transfers, pending for longer than 30 days to domestic or foreign residents, irrespective of the currency denomination of the debt.

\section{DATA AND INFORMATION}

15. The Seychelles authorities (government and CBS) will provide Fund staff with the following data and information according to the schedule provided. 


\section{The CBS will report}

Weekly (within one week from the end of the period):

- Net international reserves

- The CBS balance sheet.

- Contracts of any new external loan agreements entered into by the CBS.

- The daily average exchange rate of the Seychelles rupee for the previous five days (in Seychelles rupees per U.S. dollar) as posted by the CBS and a table on the number and size of daily transactions in the market.

- The foreign exchange cash flow.

- The results of the liquidity deposit auctions, primary treasury bill auctions, and secondary auctions.

Monthly (within 4 weeks from the end of the month):

- Monthly balance sheet of the CBS.

- The monetary survey.

- Financial soundness indicators.

- Structure of interest rates.

- Stock of government securities in circulation by holder (banks and nonbanks) and by original maturity.

\section{The Ministry of Finance will report}

Weekly (within one week from the end of the period):

- Notification of payments coming due on external debt, which were not made (increase in arrears).

Monthly (within 4 weeks from the end of the month):

- Consolidated government operations on a commitment basis and cash basis in the IMFsupported program format.

- The detailed revenues and expenditures of the central government and social security fund.

- Monthly accounts of the public non-bank financial institutions.

- Monthly treasury report.

- Stock and flow of external debt by creditor.

- Statement on budget expenditure and external debt service arrears. Data on the clearance of arrears will distinguish between domestic and external obligations and between those referring to scheduled interest payments, scheduled principal repayments, and commercial and other current transactions.

- The contracts of any new external loan agreements entered into by the government and parastatals.

16. The government and CBS will consult with Fund staff on all economic and financial measures that would have an impact on program implementation, and will provide any additional relevant information as requested by Fund staff. 


\section{APPENDIX II}

\section{SeyChelles: DebT Sustainability AnAlysis}

This debt sustainability analysis (DSA) confirms that Seychelles' public debt is unsustainable. The analysis argues that this remains the case even if a strong and sustained fiscal adjustment is implemented. A comprehensive public debt restructuring is critical for restoring debt sustainability. Nevertheless, Seychelles is likely to remain highly vulnerable to a wide variety of shocks for an extended period of time. Against this background, engagement in constructive good-faith discussions with all external creditors is critical.

\section{Structure of Public Debt and Recent Developments}

1. Seychelles's public and publicly guaranteed (PPG) debt burden is among the highest in the world. ${ }^{5}$ As of end-August 2008, the PPG debt stock is estimated at 151 percent of GDP (Table 1). External public sector debt is 94 percent of GDP (54 percent of total public debt) and is largely held by commercial and official bilateral creditors (see text chart). ${ }^{6}$ Domestic public debt outstanding accounts for about 57 percent of GDP (38 percent of total public debt), predominantly held by the domestic commercial banking sector and the Central Bank of Seychelles (CBS).

\section{The currency composition of} Seychelles' public debt has changed considerably over the last few years. Since 2006, the share of external debt has been rapidly rising - increasing from 38 percent in 2006 to 62 percent of total public debt in August-2008 - adding to severe sensitivity of debt ratios to fluctuation in the exchange rate.

\footnotetext{
${ }^{5}$ For the purpose of this DSA, public sector is defined as non-financial public sector and includes debt contracted by non-financial parastatals. The stock data and service projections are preliminary as the data have not yet been reconcilled with creditors.

${ }^{6}$ Staff understands that there is some collateralized commercial external debt.
} 
3. The maturity structure (residual basis) of the domestic public debt is skewed toward shorter maturities. More than half of domestic debt is due to mature over the course of the next two years. Thus, rollover risks may be significant in the near term.

\section{Arrears to commercial and} official creditors have been rising rapidly. Since 2006, external arrears have nearly tripled, increasing from 13 percent to more than 36 percent of GDP. As of end-August 2008, arrears to commercial creditors represented almost half of the total, and Paris Club official bilateral creditors 40 percent. Arrears to multilateral creditors are relatively small (US\$2.2 million, 0.3 percent of GDP), primarily to Arab Bank for Economic Development in Africa and OPEC.

\section{The accumulation of external} arrears accelerated in the second semester of 2008, resulting in a series of downgrades of Seychelles' external credit ratings (Table 1). Following the July non-payment and consequent acceleration of a privately-placed external amortizing note, arrears to commercial creditors increased by about 14 percent of GDP, resulting in the Standard \& Poor's downgrade of the external credit rating to SD (selected default). On October 1, 2008, Standard \& Poor's downgraded the Eurobond (US\$230 million, 9.125 percent due 2011) to "D" (default) and assigned a recovery rating of " 4 ", indicating expectation of an average recovery of 30-50 percent on defaulted debt. ${ }^{7}$

\footnotetext{
7 This downgrade was triggered by the Ministry of Finance's announcement of its intention to miss a coupon payment falling due on October 3, 2008.
}

Seychelles: External Arrears on PPG Debt, End-August 2008. (in percent of total external arrears)

External arrears by creditor

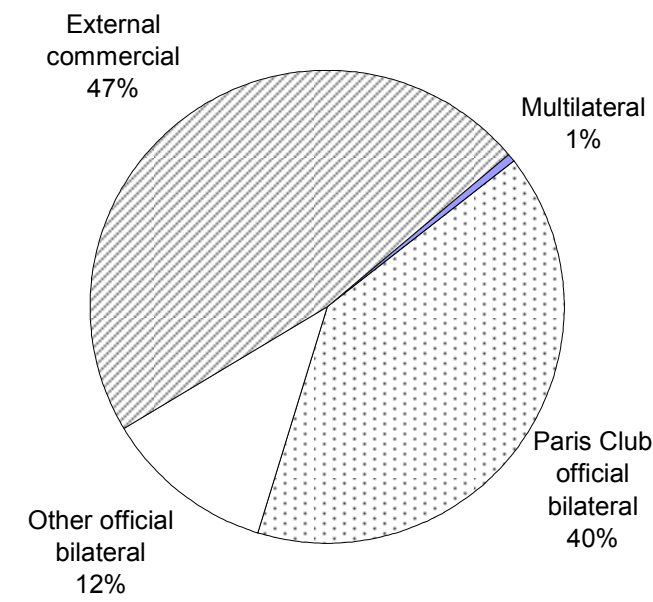

Source: Ministry of Finance; Central Bank of Seychelles, and IMF staff calculations. payment falling due on October 3,2008 . 


\section{Macroeconomic Assumptions}

The debt sustainability analysis is based on the following medium- and long-term macroeconomic assumptions, which are consistent with the framework presented in the staff report:

- $\quad$ Against the background of strong fiscal effort and the significant exchange rate adjustment accompanying floating the exchange rate, the near-term economic growth is projected to be subdued, with real GDP shrinking by about 0.5 percent in 2009 . Economic growth is expected to recover relatively fast, however, supported by the foreign direct investment in tourism (see below). Annual real GDP growth is assumed to be around 5 percent in the long term, broadly consistent with Seychelles' long-term historical average.

- $\quad$ Reflecting the pass-through of the exchange rate depreciation, inflation would peak in 2009 at about 34 percent but, supported by tighter fiscal and monetary stance, would gradually decline to its long-term level of about 3 percent by 2012 .

- $\quad$ Notwithstanding a US\$3.4 billion pipeline of approved foreign-financed projects in tourism, net FDI inflows in the medium-term are projected to decline significantly, with 2009 inflows falling by about 30 percent in absolute terms (a drop of about 4 percent of GDP) relative to its 2008 level. FDI inflows are expected to recover gradually over the medium term on account of the improved business environment following the elimination of exchange restrictions (i.e., elimination of impediments to profits repatriation), recouping its recent levels by $2012-13 .{ }^{8}$ This path reflects an assumption that going forward investors will face elevated cost of financing projects in Seychelles due to the country's higher risk premium and, more generally, higher cost and availability of capital on account of tight world-wide credit conditions and greater risk aversion. The long-term FDI-to-GDP ratio is assumed to stabilize at about 30 percent of GDP.

- Under the impulse of foreign direct investment, tourism earnings are projected to grow by 9 percent per annum in the long run. However, some moderation of tourism receipts is expected in the near term on account of slower world-wide economic growth.

- The non-interest external current account deficit is projected to improve from 26.7 percent of GDP in 2008 to 16.4 percent of GDP in 2009, mostly reflecting a significant import compression (a drop of about 10 percent) following liberalization

\footnotetext{
${ }^{8}$ FDI inflows are relatively neutral for the balance of payments as foreign-financed investments have import content of 85-90 percent and result in outflows in the form of repatriated profits. As a result, the debt sustainability outlook is not very sensitive about the specific assumption on FDI inflows.
} 
of the exchange rate regime. Over the longer term, however, the non-interest external current account deficit is projected to widen moderately to an average of about 18.5 percent of GDP, as rising tourism earnings are offset by higher tourism- and FDI-related imports and mounting repatriation abroad of investors' profits and dividends.

- $\quad$ On the fiscal front, projections assume a large and frontloaded fiscal tightening. The primary balance improves by 9.4 percentage points of GDP in 2008 and the primary surplus remains over 6 percent of GDP in 2009-11. The fiscal stance relaxes with the primary surplus gradually declining from 5.2 percent of GDP in 2012 to 3.6 percent in 2018. Government revenues are projected to average 35.5 percent of GDP in 200918 , while primary expenditures are projected to decline from 37.5 percent of GDP in 2007 to an average of about 32 percent of GDP in 2016-18.

- Debt sustainability analysis assumes no restructuring of the domestic public debt due to risks it may pose to Seychelles banking system. ${ }^{9}$ However, a period of negative (or low positive) real interest rates on long term government fixed coupon bond in 200810 significantly erodes domestic debt as inflation is high and domestic interest rates are relatively low. Substantial privatization and long-term lease income in 2008-09 reduce domestic debt, though this factor diminishes over time. In addition to the aforementioned primary surpluses, healthy real GDP growth from 2010 also aids debt reduction.

- The foreign reserves target of at least three months of prospective imports is assumed to be reached by 2015 .

\section{Non-Restructuring Scenario}

\section{The scenario is built on the assumption that external financing gaps are closed} by new external borrowing (Table 3 ). ${ }^{10}$ All external arrears are assumed to be cleared through refinancing. With a caveat of the significant uncertainty about specific terms of new external commercial borrowing of a highly indebted country with large payment arrears, we assume that Seychelles could borrow at LIBOR plus 800 basis points with 10 year maturity and one year grace period. ${ }^{11}$ While in principle a case could be made that Seychelles may currently face an even tougher terms with steeper risk premium, the analysis of this section is

\footnotetext{
${ }^{9}$ See staff report for a detailed assessment of banking sector's capacity to absorb domestic debt restructuring.

${ }^{10}$ An alternative way to think about this scenario is to treat it as if Seychelles was getting cash flow relief from its creditors that comes in the form of a flow refinancing of its financing gaps and arrears.

${ }^{11}$ The assumed risk premium is designed to mimic the average 2008 EMBI spreads on sovereign external debt of other highly indebted countries with significant vulnerabilities, for which trading of debt securities is more active.
} 
quite illuminating and should be viewed as a lower (optimistic) bound of the country's debt sustainability outlook.

7. The new borrowing scenario shows that the level of public debt would remain unsustainable (Table 2a, Figure 1a). Over the course of the next ten years, the debt-to-GDP ratio is projected to rise to over 183 percent of GDP, a level clearly inconsistent with public debt sustainability. Furthermore, the bound tests highlight that the evolution of public debt is extremely sensitive to the underlying assumptions, with even moderate shocks triggering even more problematic dynamics.

8. Correspondingly, external debt ratios rise sharply in 2009 to 128 percent of GDP due to the impact of the exchange rate depreciation and continue growing throughout the projection periods (Table $2 \mathrm{~b}$, Figure $1 \mathrm{~b}$ ). External debt-to-GDP ratio is projected to continue rising to 165 percent of GDP in 2018, leaving the economy highly vulnerable to a wide spectrum of shocks: even modest shocks to current account deficit and, importantly, nominal interest rate puts external debt indicators on the even more explosive path.

9. Given the magnitude of Seychelles' public debt burden, a comprehensive debt restructuring involving creditors accepting significant concessions is required to restore public debt sustainability. Moreover, the staff analysis suggests that even with a sharp reduction in the debt service burden consistent with the long-term ability to pay, Seychelles is likely to remain highly vulnerable to a wide variety of shocks for an extended period of time. 
Table 1. Seychelles: Public sector debt ${ }^{1}$

\begin{tabular}{|c|c|c|c|c|}
\hline & 2006 & 2007 & 2008 & 2008 \\
\hline & & & end-June & end-Aug \\
\hline & \multicolumn{4}{|c|}{ (in percent of GDP) } \\
\hline Public sector debt & 138.9 & 151.9 & 149.8 & 151.3 \\
\hline Public sector external debt & 53.1 & 77.9 & 92.3 & 94.1 \\
\hline Multilateral & 4.2 & 5.6 & 5.6 & 6.3 \\
\hline Bilateral & 18.5 & 22.5 & 25.3 & 29.0 \\
\hline Paris Club & 13.6 & 16.4 & 18.1 & 18.7 \\
\hline Others & 4.9 & 6.2 & 7.2 & 10.3 \\
\hline Commercial & 30.4 & 49.8 & 61.4 & 58.8 \\
\hline Banks & 9.8 & 11.0 & 19.6 & 17.8 \\
\hline Eurobond & 20.7 & 25.2 & 26.8 & 26.8 \\
\hline Amortizing note ${ }^{2,3}$ & 0.0 & 13.6 & 15.0 & 14.2 \\
\hline Arrears & 12.8 & 17.6 & 20.9 & 36.4 \\
\hline Multilateral & 0.0 & 0.3 & 0.2 & 0.3 \\
\hline Bilateral & 10.7 & 14.7 & 17.2 & 18.9 \\
\hline Paris Club & 10.4 & 13.1 & 14.7 & 14.7 \\
\hline Others & 0.4 & 1.6 & 2.4 & 4.2 \\
\hline Commercial & 2.0 & 2.6 & 3.6 & 17.3 \\
\hline Banks & 2.0 & 2.6 & 3.6 & 3.1 \\
\hline Eurobond & 0.0 & 0.0 & 0.0 & 0.0 \\
\hline Amortizing note ${ }^{2,3}$ & 0.0 & 0.0 & 0.0 & 14.2 \\
\hline Public sector domestic debt & 85.8 & 74.1 & 57.5 & 57.3 \\
\hline Central Bank of Seychelles & 20.8 & 18.6 & 14.2 & 15.6 \\
\hline Commercial banks & 49.6 & 41.4 & 31.9 & 31.3 \\
\hline Other financial institutions & 1.7 & 1.5 & 1.4 & 1.2 \\
\hline Parastatals & 0.0 & 0.1 & 0.0 & 0.2 \\
\hline Social Security Fund & 0.8 & 0.8 & 0.7 & 0.6 \\
\hline Pension Fund & 5.1 & 4.4 & 3.1 & 3.1 \\
\hline Others $^{4}$ & 7.7 & 7.2 & 6.4 & 5.2 \\
\hline \multicolumn{5}{|l|}{ Memorandum items: } \\
\hline Nominal GDP (in millions of Seychelles rupees) & 5,342 & 6,113 & 7,878 & 7,878 \\
\hline Nominal GDP (in millions of US dollars) & 968 & 912 & 859 & 859 \\
\hline
\end{tabular}

Sources: Ministry of Finance; Central Bank of Seychelles, and IMF staff calculations

${ }^{1}$ Preliminary and subject to reconcilliation with creditors.

${ }^{2}$ Changes due to Euro appreciation against the US\$.

${ }^{3}$ In 2008, includes accelerated ammortizing notes (Euro 83.05 million, under repayment schedule 1).

${ }^{4}$ This includes private individuals and companies. 
Table 2a. Seychelles: Public Sector Debt Sustainability Framework for Non-Restructuring Scenario, 2005-2018

(In percent of GDP, unless otherwise indicated)

\begin{tabular}{|c|c|c|c|c|c|c|c|c|c|c|c|c|c|c|}
\hline & \multicolumn{3}{|c|}{ Actual } & \multicolumn{11}{|c|}{ Projections } \\
\hline & 2005 & 2006 & 2007 & 2008 & 2009 & 2010 & 2011 & 2012 & 2013 & 2014 & 2015 & 2016 & 2017 & 2018 \\
\hline $\begin{array}{l}\text { Public sector debt } 1 / \\
\text { o/w foreign-currency denominated }\end{array}$ & $\begin{array}{r}147.1 \\
46.6\end{array}$ & $\begin{array}{r}139.5 \\
53.7\end{array}$ & $\begin{array}{r}151.9 \\
77.9\end{array}$ & $\begin{array}{r}150.5 \\
97.8\end{array}$ & $\begin{array}{l}\mathbf{1 6 8 . 6} \\
128.0\end{array}$ & $\begin{array}{l}162.8 \\
129.4\end{array}$ & $\begin{array}{l}164.1 \\
138.4\end{array}$ & $\begin{array}{l}164.8 \\
144.5\end{array}$ & $\begin{array}{l}166.7 \\
150.4\end{array}$ & $\begin{array}{l}167.6 \\
155.6\end{array}$ & $\begin{array}{l}170.1 \\
159.7\end{array}$ & $\begin{array}{l}173.8 \\
162.5\end{array}$ & $\begin{array}{l}\mathbf{1 7 8 . 1} \\
164.2\end{array}$ & $\begin{array}{l}\mathbf{1 8 2 . 7} \\
164.7\end{array}$ \\
\hline $\begin{array}{l}\text { Change in public sector debt } \\
\text { Identified debt-creating flows }(4+7+12)\end{array}$ & $\begin{array}{l}-15.1 \\
-11.0\end{array}$ & $\begin{array}{l}-7.6 \\
-5.6\end{array}$ & $\begin{array}{r}12.4 \\
0.8\end{array}$ & $\begin{array}{r}-1.4 \\
-12.6\end{array}$ & $\begin{array}{l}18.1 \\
223\end{array}$ & $\begin{array}{l}-5.8 \\
-6.7\end{array}$ & $\begin{array}{l}1.3 \\
2.0\end{array}$ & $\begin{array}{l}0.7 \\
1.5\end{array}$ & $\begin{array}{l}1.9 \\
3.1\end{array}$ & 0.9 & $\begin{array}{l}2.5 \\
2.9\end{array}$ & $\begin{array}{l}3.7 \\
3.7\end{array}$ & $\begin{array}{l}4.3 \\
4.3\end{array}$ & $\begin{array}{l}4.6 \\
4.6\end{array}$ \\
\hline Primary deficit & -7.3 & 0.6 & 2.3 & -7.1 & -6.2 & -6.6 & -6.8 & -5.8 & -5.5 & -4.9 & -4.2 & -3.8 & -3.6 & -3.6 \\
\hline Revenue and grants & 42.1 & 43.4 & 36.2 & 35.9 & 35.7 & 35.5 & 35.5 & 35.5 & 35.5 & 35.5 & 35.5 & 35.5 & 35.5 & 35.5 \\
\hline Primary (noninterest) expenditure & 34.8 & 43.9 & 38.5 & 28.8 & 29.5 & 28.9 & 28.8 & 29.7 & 30.0 & 30.6 & 31.3 & 31.7 & 31.9 & 31.9 \\
\hline Automatic debt dynamics $2 /$ & -2.4 & -7.5 & 0.7 & -2.2 & 32.5 & 0.6 & 9.5 & 8.1 & 9.3 & 7.3 & 7.7 & 8.1 & 8.5 & 8.7 \\
\hline Contribution from interest rate/growth differential $3 /$ & -2.4 & -7.6 & -10.2 & -25.2 & -10.9 & -6.5 & 4.6 & 5.6 & 7.0 & 7.3 & 7.7 & 8.1 & 8.5 & 8.7 \\
\hline Of which contribution from real interest rate & 9.2 & 3.5 & -1.3 & -21.5 & -11.5 & -1.4 & 12.0 & 13.2 & 14.6 & 15.0 & 15.5 & 16.0 & 16.5 & 16.9 \\
\hline Of which contribution from real GDP growth & -11.5 & -11.1 & -8.9 & -3.7 & 0.6 & -5.1 & -7.3 & -7.6 & -7.6 & -7.7 & -7.8 & -7.9 & -8.0 & -8.2 \\
\hline Contribution from exchange rate depreciation $4 /$ & 0.0 & 0.2 & 10.8 & 23.0 & 43.4 & 7.1 & 4.8 & 2.5 & 2.3 & 0.0 & 0.0 & 0.0 & 0.0 & 0.0 \\
\hline Other identified debt-creating flows & -1.3 & 1.3 & -2.2 & -3.2 & -4.0 & -0.8 & -0.7 & -0.7 & -0.7 & -0.6 & -0.6 & -0.6 & -0.6 & -0.5 \\
\hline Privatization receipts (negative) & -1.3 & -3.8 & -2.2 & -3.2 & -4.0 & -0.8 & -0.7 & -0.7 & -0.7 & -0.6 & -0.6 & -0.6 & -0.6 & -0.5 \\
\hline Recognition of implicit or contingent liabilities & 0.0 & 5.1 & 0.0 & 0.0 & 0.0 & 0.0 & 0.0 & 0.0 & 0.0 & 0.0 & 0.0 & 0.0 & 0.0 & 0.0 \\
\hline Other (specify, e.g. bank recapitalization) & 0.0 & 0.0 & 0.0 & 0.0 & 0.0 & 0.0 & 0.0 & 0.0 & 0.0 & 0.0 & 0.0 & 0.0 & 0.0 & 0.0 \\
\hline Residual, including asset changes (2-3) & -4.1 & -2.0 & 11.7 & 11.1 & -4.2 & 1.0 & -0.7 & -0.9 & -1.2 & -0.8 & -0.4 & 0.0 & 0.0 & 0.0 \\
\hline Public sector debt-to-revenue ratio $1 /$ & 349.5 & 321.6 & 419.5 & 419.5 & 471.8 & 458.6 & 462.1 & 464.5 & 468.9 & 472.2 & 479.2 & 489.8 & 502.0 & 514.9 \\
\hline $\begin{array}{l}\text { Gross financing need } 5 / \\
\text { in billions of U.S. dollars }\end{array}$ & $\begin{array}{r}61.3 \\
0.5\end{array}$ & $\begin{array}{r}55.9 \\
0.5\end{array}$ & $\begin{array}{r}44.3 \\
0.4\end{array}$ & $\begin{array}{r}47.4 \\
0.4\end{array}$ & $\begin{array}{r}49.7 \\
0.4\end{array}$ & $\begin{array}{r}34.1 \\
0.3\end{array}$ & $\begin{array}{r}66.7 \\
0.6\end{array}$ & $\begin{array}{r}31.6 \\
0.3\end{array}$ & $\begin{array}{r}34.8 \\
0.3\end{array}$ & $\begin{array}{r}34.7 \\
0.4\end{array}$ & $\begin{array}{r}33.9 \\
0.4\end{array}$ & $\begin{array}{r}35.3 \\
0.4\end{array}$ & $\begin{array}{r}38.8 \\
0.5\end{array}$ & $\begin{array}{r}42.5 \\
0.6\end{array}$ \\
\hline \multicolumn{15}{|l|}{ Key Macroeconomic and Fiscal Assumptions } \\
\hline Real GDP growth (in percent) & 7.5 & 8.3 & 7.3 & 3.1 & -0.5 & 3.5 & 5.0 & 5.0 & 5.0 & 5.0 & 5.0 & 5.0 & 5.0 & 5.0 \\
\hline Average nominal interest rate on public debt (in percent) 6/ & 3.7 & 4.2 & 6.1 & 7.5 & 17.4 & 11.7 & 14.0 & 11.9 & 12.6 & 12.8 & 13.0 & 13.2 & 13.3 & 13.3 \\
\hline Average nominal interest rate on forex debt (in percent) $6 /$ & 1.7 & 2.6 & 7.5 & 3.5 & 16.6 & 12.0 & 15.6 & 13.1 & 13.4 & 13.5 & 13.5 & 13.6 & 13.6 & 13.7 \\
\hline Average real interest rate (nominal rate minus change in GDP deflator, in percent) & 5.8 & 2.7 & -0.6 & -17.5 & -9.8 & -0.6 & 8.4 & 8.9 & 9.7 & 9.9 & 10.1 & 10.3 & 10.4 & 10.4 \\
\hline Nominal depreciation of local currency (LC per dollar) & 0.0 & 0.4 & 21.4 & 36.8 & 48.2 & 5.8 & 3.6 & 1.7 & 1.5 & 0.0 & 0.0 & 0.0 & 0.0 & 0.0 \\
\hline Nominal appreciation (increase in US dollar value of local currency, in percent) & 0.0 & -0.4 & -17.6 & -26.9 & -32.5 & -5.5 & -3.4 & -1.7 & -1.5 & 0.0 & 0.0 & 0.0 & 0.0 & 0.0 \\
\hline Inflation rate (GDP deflator, in percent) & -2.1 & 1.5 & 6.7 & 25.0 & 27.2 & 12.2 & 5.5 & 3.1 & 2.9 & 2.9 & 2.9 & 2.9 & 2.9 & 2.9 \\
\hline Growth of real primary spending (deflated by GDP deflator, in percent) & 3.4 & 36.9 & -6.0 & -23.0 & 2.1 & 1.5 & 4.4 & 8.3 & 6.3 & 7.0 & 7.4 & 6.3 & 5.7 & 5.0 \\
\hline Primary deficit & -7.3 & 0.6 & 2.3 & -7.1 & -6.2 & -6.6 & -6.8 & -5.8 & -5.5 & -4.9 & -4.2 & -3.8 & -3.6 & -3.6 \\
\hline \multicolumn{15}{|l|}{ A. Alternative Scenarios } \\
\hline A1. Key variables are at their historical averages in 2008-12 7/ & & & & 150.5 & 181.7 & 193.6 & 202.1 & 208.2 & 213.9 & 217.3 & 221.2 & 225.6 & 230.1 & 234.8 \\
\hline A2. No policy change (constant primary balance) in $2008-12$ & & & & 150.5 & 177.2 & 180.3 & 191.6 & 201.8 & 213.6 & 223.7 & 235.3 & 248.3 & 262.1 & 276.7 \\
\hline \multicolumn{15}{|l|}{ B. Bound Tests } \\
\hline B1. Real interest rate is at baseline plus one-half standard deviations & & & & 150.5 & 178.4 & 182.6 & 195.6 & 209.3 & 225.9 & 242.4 & 262.3 & 285.6 & 311.9 & 341.0 \\
\hline B2. Real GDP growth is at baseline minc & & & & 150.5 & 170.9 & 167.7 & 172.0 & 176.2 & 182.3 & 187.9 & 195.7 & 205.7 & 217.0 & 229.4 \\
\hline $\begin{array}{l}\text { B3. Primary balance is at baseline minus one standard deviation } \\
\text { and and }\end{array}$ & & & & 150.5 & 174.2 & 174.1 & 181.6 & 188.8 & 197.6 & 205.5 & 215.3 & 226.8 & 239.3 & 252.5 \\
\hline B4. Combination of B1-B3 using one-quarter standard deviation shocks & & & & 150.5 & 175.2 & 175.9 & 184.7 & 193.5 & 204.3 & 214.4 & 226.9 & 241.7 & 258.0 & 275.7 \\
\hline B5. One time 15 percent additional real depreciation in $2009 \mathrm{~g} /$ & & & & 150.5 & 206.8 & 201.2 & 204.7 & 207.3 & 211.6 & 214.5 & 219.1 & 225.2 & 232.0 & 239.2 \\
\hline B6. 10 percent of GDP increase in other debt-creating flows in 2009 & & & & 150.5 & 178.6 & 172.9 & 174.8 & 175.9 & 178.4 & 179.9 & 182.9 & 187.3 & 192.3 & 197.5 \\
\hline
\end{tabular}

$1 /$ Public sector covers non-finacial public sector and the IMF loan to the CBS. Debt is on a gross basis. External and domestic financing gaps are assumed to be closed by additional borrowing. 2/ Derived as $[(r-p(1+g)-g+a e(1+r)] /(1+g+p+g p))$ times previous period debt ratio, with $r=$ interest rate; $p=$ growth rate of GDP deflator; $g=$ real GDP growth rate; $a=$ share of foreign-currency denominated debt; and $\mathrm{e}=$ nominal exchange rate depreciation (measured by increase in local currency value of U.S. dollar).

$3 /$ The real interest rate contribution is derived from the denominator in footnote $2 /$ as $r-\pi(1+g)$ and the real growth contribution as $-g$.

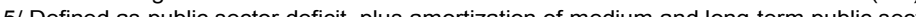

ector debt, plus short-term debt at end of previous period.

$6 /$ Derived as nominal interest expenditure divided by previous period debt stock.

7/ The key variables include real GDP growth; real interest rate; and primary balance in percent of GDP.

8/ The implied change in other key variables under this scenario is discussed in the text.

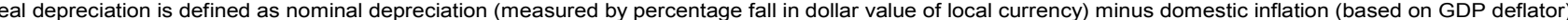

$10 /$ Assumes that key variables (real GDP growth, real interest rate, and other identified debt-creating flows) remain at the level of the last projection year. 
Table 2b. Seychelles: External Debt Sustainability Framework for Non-Restructuring Scenario, 2005-2018

(In percent of GDP, unless otherwise indicated)

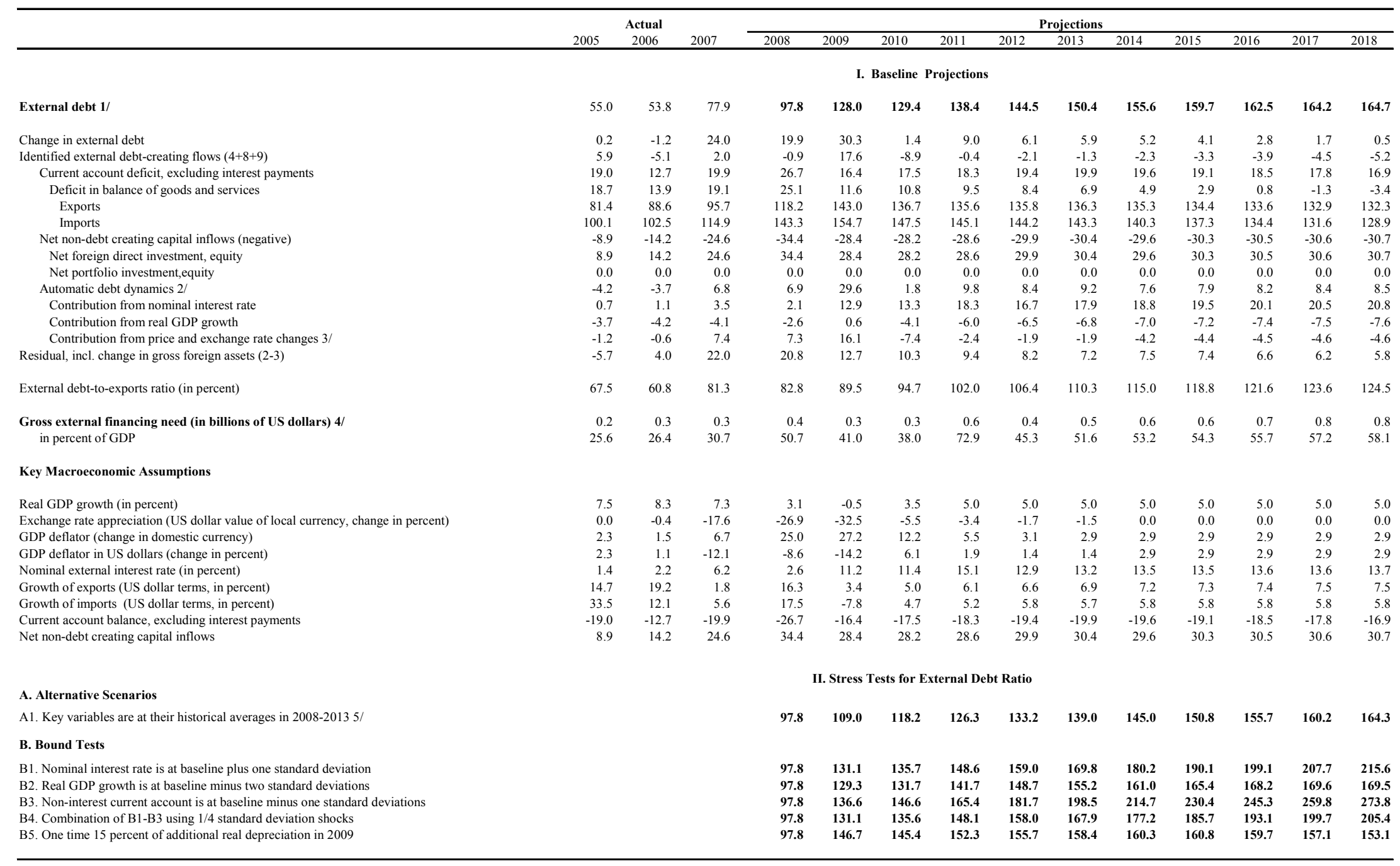

1/ External financing gaps and arrears are assumed to be closed by external borrowing at LIBOR plus 800bps, with 10 year maturity and one year grace period.

2/ Derived as $[\mathrm{r}-\mathrm{g}-\rho(1+\mathrm{g})+\varepsilon \alpha(1+\mathrm{r})] /(1+\mathrm{g}+\rho+\mathrm{g} \rho)$ times previous period debt stock, with $\mathrm{r}=$ nominal effective interest rate on external debt; $\rho=$ change in domestic GDP deflator in US dollar terms,

$\mathrm{g}=$ real GDP growth rate, $\mathrm{e}=$ nominal appreciation (increase in dollar value of domestic currency), and $\mathrm{a}=$ share of domestic-currency denominated debt in total external deb.

$3 /$ The contribution from price and exchange rate changes is defined as $[-\rho(1+\mathrm{g})+\varepsilon \alpha(1+\mathrm{r})] /(1+\mathrm{g}+\rho+\mathrm{g} \rho)$ times previous period debt stock. $\rho$ increases with an appreciating domestic currency $(\varepsilon>0)$

and rising inflation (based on GDP deflator).

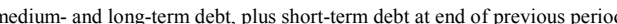

作 
Table 3. Seychelles: Balance of Payments: Non-Restructuring Scenario, 2007-18

(in millions of U.S. dollars)

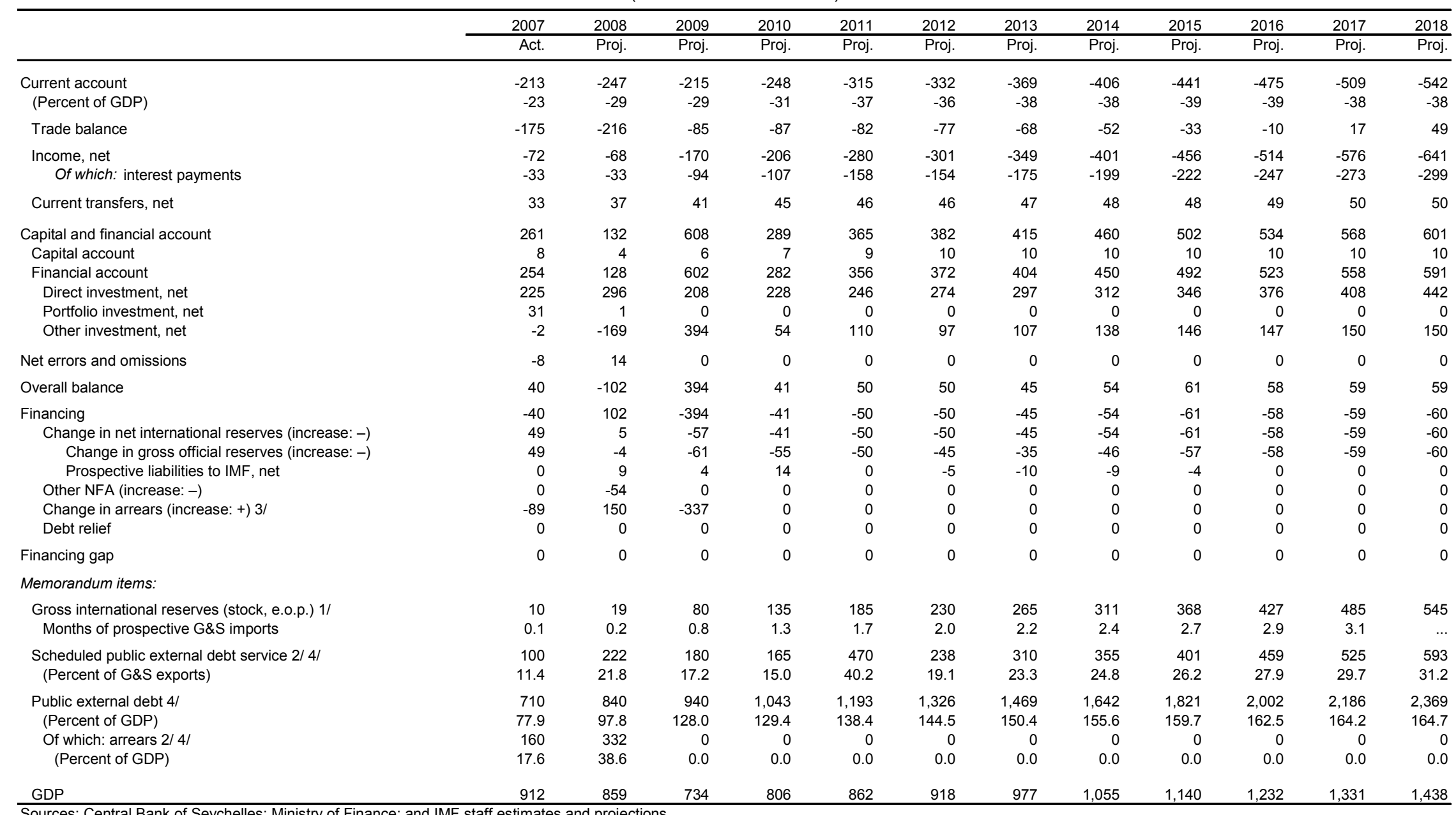

Sources: Central Bank of Seychelles; Ministry of Finance; and IMF staff estimates and projections

1/ Starting with 2007, referes to CBS gross international reserves net of blocked deposits and project accounts.

2/ Assuming external financing gaps are closed by new borrowing at LIBOR plus 800 bps and no debt restructuring.

$3 /$ In 2008, includes accelerated promissory notes. In 2008-09, includes repayment of accrued investor profits.

4/ Preliminary and subject to reconcilliation with creditors. 
Figure 1a. Public DSA: Bound Tests for Non-Restructuring Scenario 1/ (Public debt in percent of GDP)
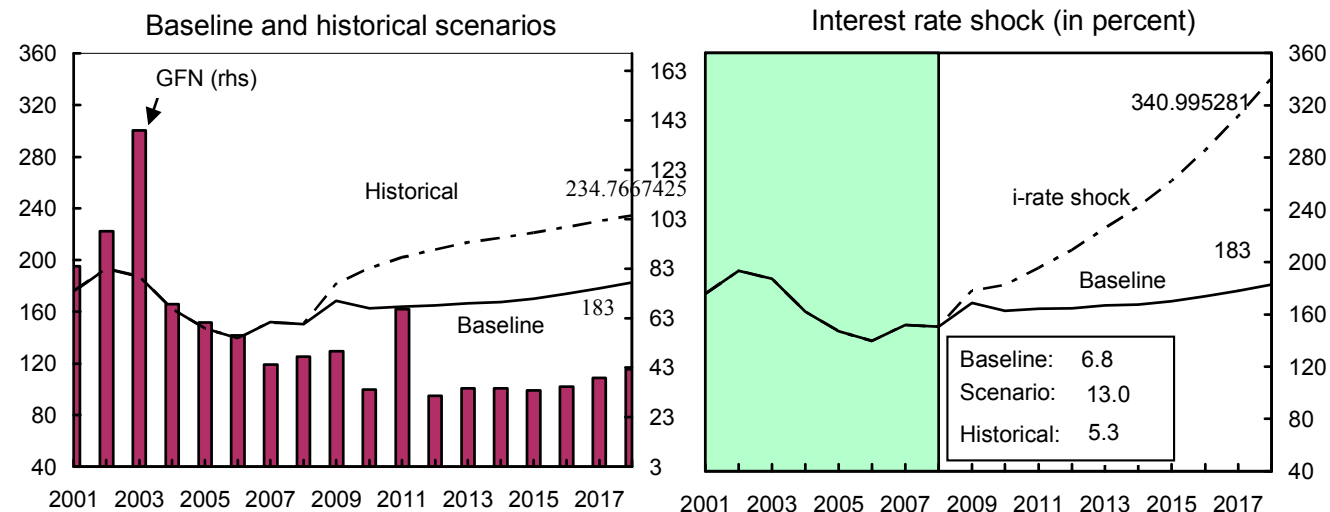

200120032005200720092011201320152017

Primary balance shock and no policy change scenarios

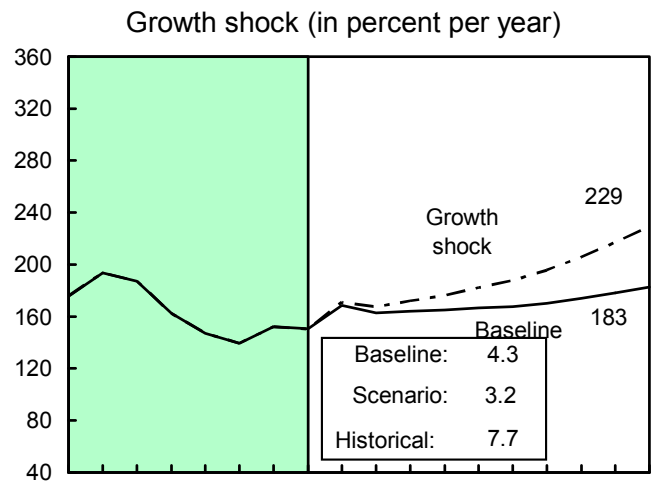
(constant primary balance)

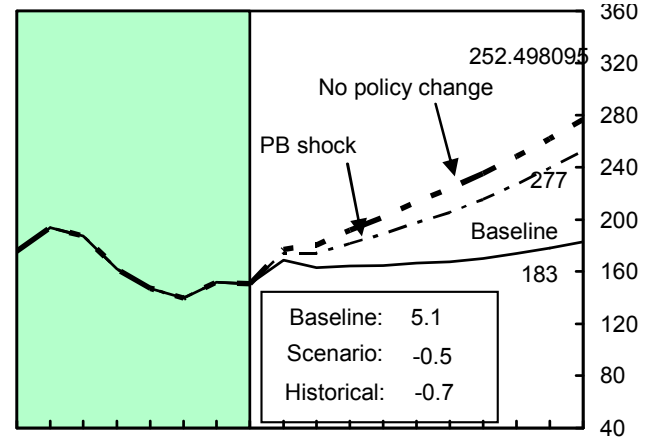

200120032005200720092011201320152017

200120032005200720092011201320152017
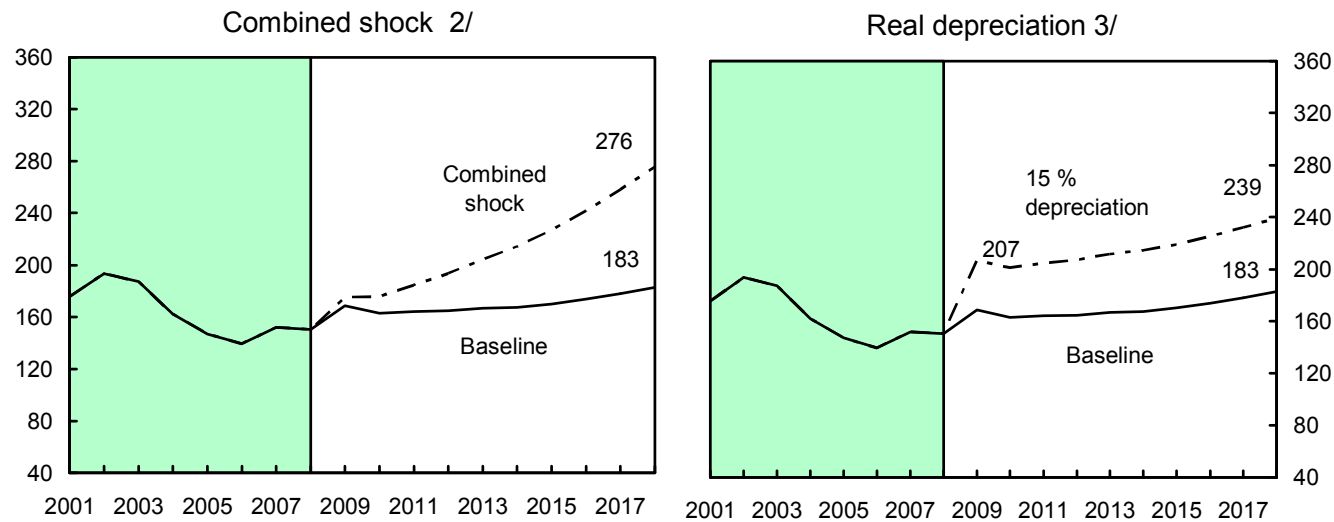

200120032005200720092011201320152017

Sources: International Monetary Fund, Country desk data, and staff estimates.

$1 /$ Shaded areas represent actual data. Individual shocks are permanent one standard deviation shocks (two s.d. for growth). Figures in the boxes represent average projections for the respective variables in the baseline and scenario being presented. Ten-year historical average for the variable is also shown.

2/ Permanent 1/4 standard deviation shocks applied to real interest rate, growth rate, and primary balance. $3 /$ One-time additional real depreciation of 15 percent in 2009, with real depreciation defined as nominal depreciation (measured by percentage fall in dollar value of local currency) minus domestic inflation (based on GDP deflator). 
Figure 1b. External DSA: Bound Tests for Non-Restructuring Scenario 1/ (External debt in percent of GDP)

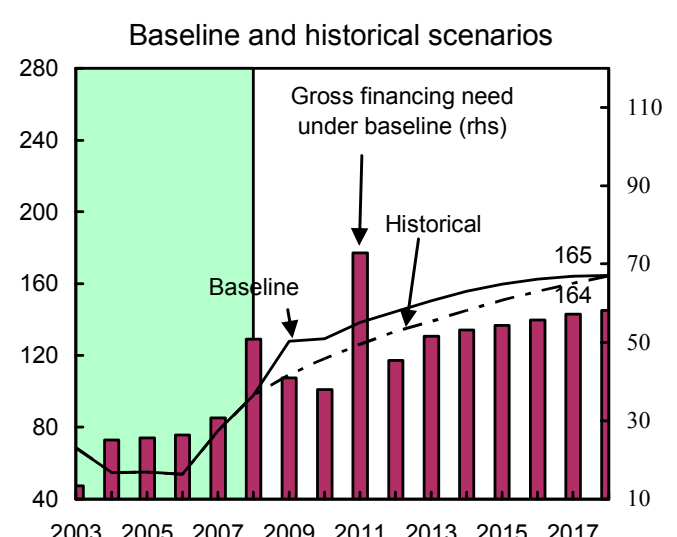

20032005200720092011201320152017

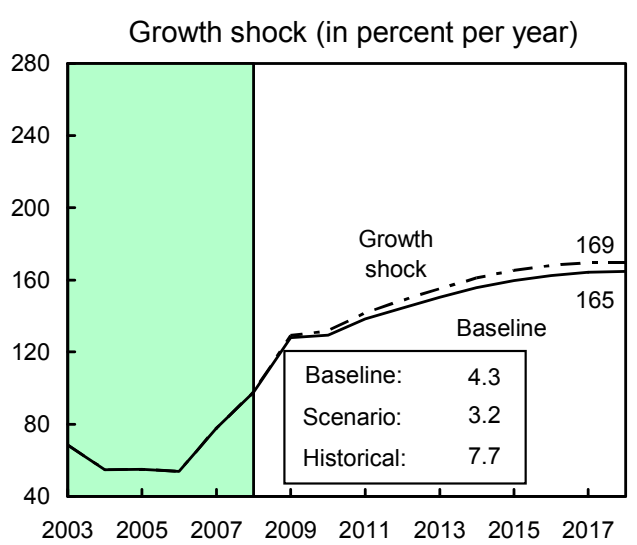

Combined shock $2 /$

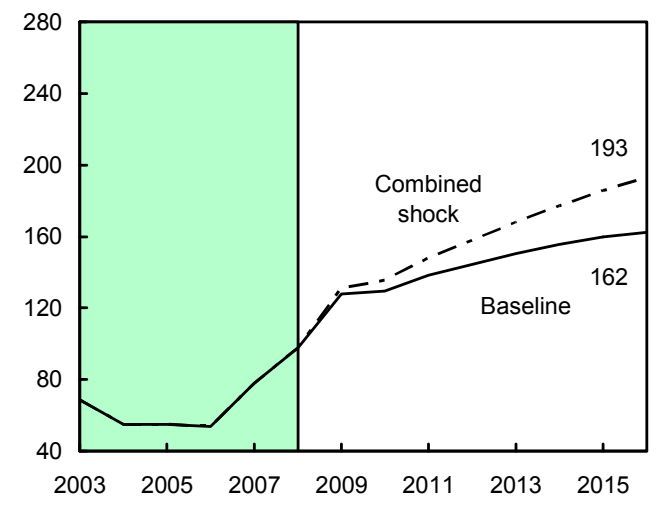

Interest rate shock (in percent)

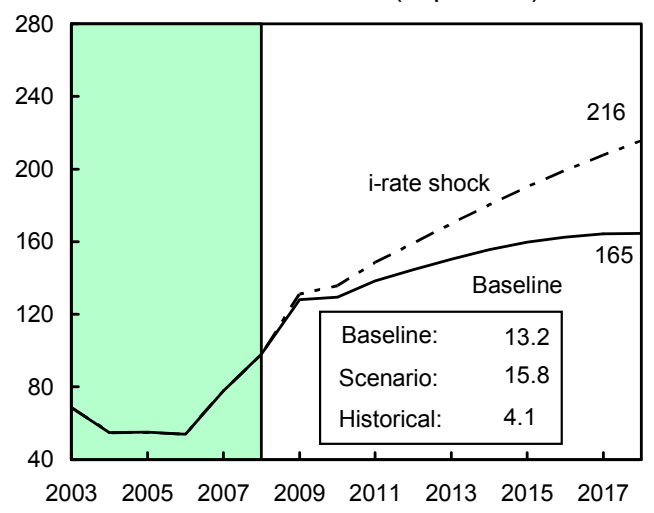

Non-interest current account shock

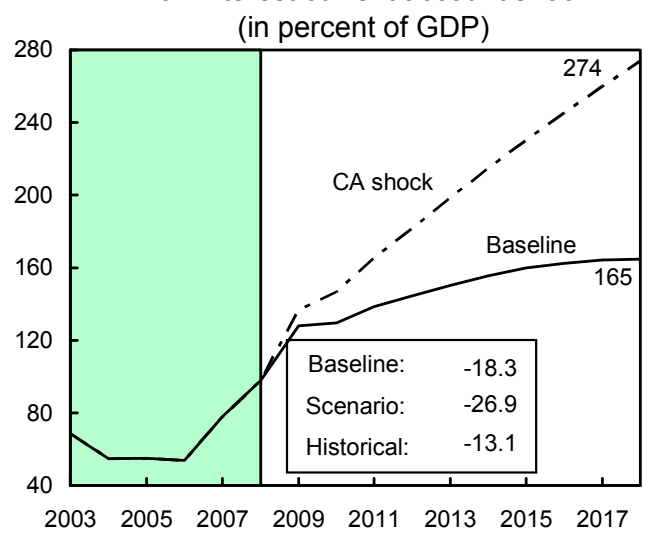

$200320052007200920112013 \quad 20152017$

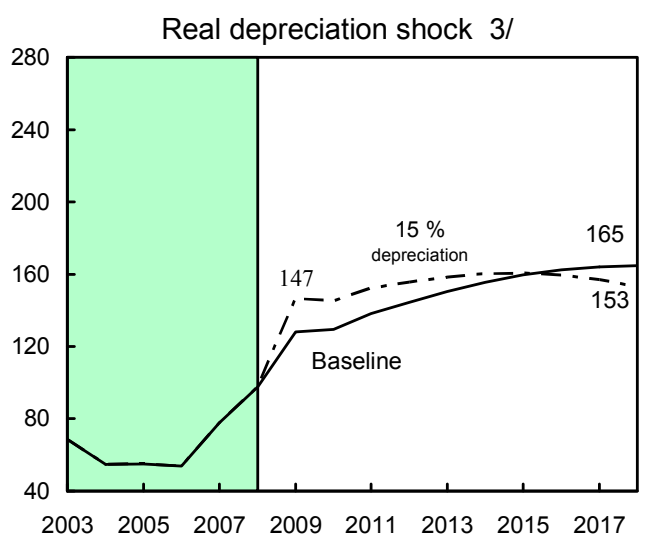

Sources: International Monetary Fund, Country desk data, and staff estimates.

1 / External financing gap is assumed to be closed by external borrowing at LIBOR plus $800 \mathrm{bps}$, with 10 year maturity and one year grace period. Shaded areas represent actual data. Individual shocks are permanent one standard deviation shocks (two standard deviations for growth shock). Figures in the boxes represent average projections for the respective variables in the baseline and scenario being presented. Ten-year historical average for the variable is also shown.

2/ Permanent 1/4 standard deviation shocks applied to real interest rate, growth rate, and current account balance.

3/ One-time real depreciation of additional 15 percent occurs in 2009. 


\section{INTERNATIONAL MONETARY FUND}

\section{SEYCHELLES}

Staff Report for the 2008 Article IV Consultation and Request for a Stand-By Arrangement-Informational Annex

Prepared by the African Department (In consultation with other departments)

Approved by Thomas Krueger (AFR) and Philip Gerson (SPR)

October 31, 2008

- $\quad$ Relations with the Fund.

- Joint World Bank-IMF Work Program. Joint Management Action Plan.

- $\quad$ Relations with the African Development Bank Group.

- $\quad$ Statistical Issues. Assesses the quality of statistical data. 


\section{Seychelles: Relations With THE FUND}

(As of September 30, 2008)

I. Membership Status: Joined 6/30/77. Article VIII.

II. General Resources Account

Quota

Fund holdings of currency

Reserve Position in Fund

III. SDR Department

Net cumulative allocation

Holdings

IV. Outstanding Purchases and

Loans:

V. Financial Arrangements: $\underline{\text { SDR Million }}$

8.80

8.80

0.00

$\underline{\text { SDR Million }}$

0.41

0.00

None

None $\frac{\text { \% Quota }}{100.0}$
99.97
0.04

$\%$ Allocations

100.0

0.70

VI. Projected Obligations to the Fund (SDR Million: based on existing use of resources and present holdings of SDRs):

\begin{tabular}{l|ccccc}
\hline & \multicolumn{5}{|c}{ Forthcoming } \\
\hline & $\mathbf{2 0 0 8}$ & $\mathbf{2 0 0 9}$ & $\mathbf{2 0 1 0}$ & $\mathbf{2 0 1 1}$ & $\mathbf{2 0 1 2}$ \\
Principal & & & & & \\
Charges/interest & 0.00 & 0.01 & 0.01 & 0.01 & 0.01 \\
Total & 0.00 & 0.01 & 0.01 & 0.01 & 0.01 \\
\hline
\end{tabular}

VII. Implementation of HIPC Initiative: Not applicable

\section{Safeguards Assessments:}

The Central Bank of Seychelles (CBS) has not previously been subject to a safeguards assessment. The assessment conducted in connection with the prospective stand-by arrangement is now substantially complete and included a staff visit to the CBS in September/October 2008. Staff found high risks in all areas of the CBS' safeguards framework. The authorities agreed to implement remedial measures, including steps to be monitored under the program. 


\section{Exchange Rate Arrangement:}

On October 9, 2006, the Central Bank revised the composition of the basket of currencies that determines the value of the Seychelles rupee. The new basket is composed of three currencies (instead of previously six): the euro (59.1 percent), the pound sterling (30.2 percent), and the U.S. dollar (10.7 percent). With the revision of the basket, the appreciation limit of US\$ $1=$ SR5.50, which was introduced on July 1 , 2003, was removed. From October 2006 to October 2007, the rupee was gradually devalued to SR/US\$8, and has been kept at this level since then.

Seychelles has maintained a number of restrictions on current international transactions subject to Fund jurisdiction under Article VIII Sections 2, 3, and 4, including a restriction on the transfer of profits and dividends, and a foreign exchange allocation mechanism. Exchange market liberalization will set the stage for the elimination of restrictions on the making of payments and transfers for current international transactions that are subject to Fund approval under Article VIII.

\section{Article IV Consultations:}

Seychelles is currently on a 12-month consultation cycle. The 2006 Article IV consultation was concluded by the Executive Board on March 27, 2007. 
XI. Technical Assistance (1999-December 2007):

\begin{tabular}{|c|c|c|c|}
\hline Department & Head of Mission & Subject & Date \\
\hline STA/AFR & Mr. Dublin & $\begin{array}{l}\text { Assess statistical } \\
\text { databases. }\end{array}$ & March 1999 \\
\hline STA & Mr. Pritchett & $\begin{array}{l}\text { Advise on government } \\
\text { finance statistics. }\end{array}$ & March 2000 \\
\hline FAD & Mr. Sunley & $\begin{array}{l}\text { Review indirect taxes, } \\
\text { including customs duties. }\end{array}$ & June 2000 \\
\hline MAE & Ms. Brenner & $\begin{array}{l}\text { Module } 2 \text { assessment of } \\
\text { offshore financial center } \\
\text { and measures to combat } \\
\text { money laundering and the } \\
\text { financing of terrorism. }\end{array}$ & June/July 2002 \\
\hline MFD/LEG & Ms. Vadasz & $\begin{array}{l}\text { Advise on the redrafting of } \\
\text { the Central Bank of } \\
\text { Seychelles Act and the } \\
\text { Financial Institutions Act. }\end{array}$ & $\begin{array}{l}\text { January/ February } \\
2003\end{array}$ \\
\hline MFD/LEG & Mr. Darbar & $\begin{array}{l}\text { Anti-money laundering } \\
\text { and combating the } \\
\text { financing of terrorism and } \\
\text { banking supervision issues }\end{array}$ & July/August 2004 \\
\hline STA & Mr. Rajcoomar & $\begin{array}{l}\text { Multisector } \\
\text { statistics/GDDS mission }\end{array}$ & August 2004 \\
\hline STA & Mr. Freeman & National Accounts/CPI & May/June 2005 \\
\hline MFD/LEG & Mr. Lonnberg & $\begin{array}{l}\text { Strengthening Capacity in } \\
\text { Critical Central Banking } \\
\text { Areas, including } \\
\text { AML/CFT-Legal, } \\
\text { Institutional, and } \\
\text { Supervisory Frameworks }\end{array}$ & July 2006 \\
\hline LEG & Mr. Beekarry & $\begin{array}{l}\text { Advise on AML/CFT } \\
\text { measures and the } \\
\text { establishment of the FIU }\end{array}$ & $\begin{array}{l}\text { September/October } \\
2006\end{array}$ \\
\hline STA & Mr. Alexander & $\begin{array}{l}\text { National } \\
\text { accounts/CPI/GDDS }\end{array}$ & $\begin{array}{l}\text { October/ } \\
\text { November } 2006\end{array}$ \\
\hline
\end{tabular}




\begin{tabular}{|c|c|c|c|}
\hline Department & Head of Mission & Subject & Date \\
\hline $\mathrm{MCM}$ & Mr. Bartholomew & $\begin{array}{l}\text { Multipurpose mission: } \\
\text { Monetary operations, } \\
\text { monetary research, } \\
\text { banking supervision, } \\
\text { payment systems, foreign } \\
\text { exchange markets, and } \\
\text { nonbank financial } \\
\text { institution supervision. }\end{array}$ & $\begin{array}{l}\text { November/ } \\
\text { December } 2007\end{array}$ \\
\hline STA & Mr. Dessart & $\begin{array}{l}\text { Dissemination of GDDS } \\
\text { National Summary Data } \\
\text { Page }\end{array}$ & April 2008 \\
\hline STA & Mr. Armknecht & Consumer price index & April 2008 \\
\hline $\mathrm{MCM}$ & Mr. Faulk & $\begin{array}{l}\text { Banking supervision, } \\
\text { drafting of new financial } \\
\text { sector related regulations }\end{array}$ & April 2008 \\
\hline $\mathrm{MCM}$ & Mr. Robotham & $\begin{array}{l}\text { National payment systems } \\
\text { project }\end{array}$ & May/June 2008 \\
\hline FAD & Mr. Khemani & $\begin{array}{l}\text { Strengthening expenditure } \\
\text { rationalization and budget } \\
\text { management }\end{array}$ & July 2008 \\
\hline LEG & Mr. Baban & $\begin{array}{l}\text { Exchange Rate and } \\
\text { Exchange Control } \\
\text { Regimes }\end{array}$ & September 2008 \\
\hline FIN & Mr. Hauge & Safeguards assessment & October 2008 \\
\hline
\end{tabular}

XII. Resident Representative None 


\section{Seychelles: JoInt World BANK-IMF Work Program, 2008-09}

(As of October 24, 2008)

\begin{tabular}{|c|c|c|c|}
\hline Title & Products & $\begin{array}{c}\text { Provisional } \\
\text { timing of } \\
\text { mission }\end{array}$ & $\begin{array}{c}\text { Expected } \\
\text { delivery date }\end{array}$ \\
\hline \multicolumn{4}{|c|}{ A. Mutual information on relevant work programs } \\
\hline Bank & $\begin{array}{l}\text { A. Strategy and Analytical Work } \\
\text { Interim Strategy Note } \\
\text { Public Expenditure Review (PER) } \\
\text { Public Expenditure Review (PER, Phase 2) } \\
\text { Update to FIAS report (improving the business } \\
\text { environment and private sector development) } \\
\text { Poverty Assessment Report } \\
\text { Joint Country Procurement Assessment Report (CPAR) } \\
\text { and Country Financial Accountability Assessment (CFAA) } \\
\text { B. Ongoing and New Projects } \\
\text { GEF grant implementation (tsunami reconstruction, } \\
\text { disaster management, fisheries capacity) } \\
\text { Development Policy Loan (DPL 1) } \\
\text { Development Policy Loan (DPL 2) }\end{array}$ & $\begin{array}{l}\text { Ongoing } \\
\text { Identification } \\
\text { mission: } \\
\text { November } 2008 \\
\text { Identification } \\
\text { mission: } \\
\text { November } 2009\end{array}$ & $\begin{array}{l}\text { January } 2009 \\
\text { April } 2009 \\
\text { February } 2010 \\
\text { February } 2010 \\
\text { October } 2009\end{array}$ \\
\hline Fund & $\begin{array}{l}\text { Program and surveillance work } \\
\text { 1. Article IV consultation and approval of 2-year Stand-By } \\
\text { Arrangement (SBA) } \\
\text { 2. Quarterly program and financing assurances reviews under the } \\
\text { SBA } \\
\qquad \text { - } \quad \text { First review } \\
\quad \text { - Third review } \\
\text { - Fourth review (if needed) } \\
\text { 3. Discussion on medium-term structural reform agenda that } \\
\text { could be supported by a successor arrangement under the EFF. } \\
\text { Technical assistance and capacity building } \\
\text { 1. FAD technical assistance mission on tax policy and revenue } \\
\text { administration review. } \\
\text { 2. MCM technical assistance on reforming the monetary policy } \\
\text { framework (long-term monetary advisor, automation of interbank } \\
\text { market, reserve money management) strengthening bank } \\
\text { supervision, and CBS governance. } \\
\text { 3. MCM technical assistance on public debt management }\end{array}$ & $\begin{array}{l}\text { September } 2009 \\
\text { February } 2009 \\
\text { May } 2009 \\
\text { August } 2009 \\
\text { November } 2009 \\
\text { August 2009 } \\
\text { (preliminary) } \\
\\
\text { First quarter } \\
\text { 2009 } \\
\text { Ongoing }\end{array}$ & $\begin{array}{l}\text { April } 2009 \\
\text { July } 2009 \\
\text { October } 2009 \\
\text { January } 2010 \\
\\
\text { October } 2009 \\
\text { (preliminary) }\end{array}$ \\
\hline
\end{tabular}




\begin{tabular}{|c|c|c|c|}
\hline Title & Products & $\begin{array}{c}\text { Provisional } \\
\text { timing of } \\
\text { mission }\end{array}$ & $\begin{array}{c}\text { Expected } \\
\text { delivery date }\end{array}$ \\
\hline \multicolumn{4}{|c|}{ B. Requests for work program inputs } \\
\hline $\begin{array}{l}\text { Bank } \\
\text { request to } \\
\text { Fund }\end{array}$ & $\begin{array}{l}\text { Medium-term macro-economic and fiscal framework to inform } \\
\text { Public Expenditure Reviews } \\
\text { Debt Sustainability Analysis }\end{array}$ & $\begin{array}{l}\text { n.a. } \\
\text { n.a. }\end{array}$ & $\begin{array}{l}\text { October } 2009 \\
\text { October } 2009\end{array}$ \\
\hline $\begin{array}{l}\text { Fund } \\
\text { request to } \\
\text { Bank }\end{array}$ & $\begin{array}{l}\text { 1. Assessment of the poverty impact of a devaluation, strategy on } \\
\text { strengthening the social safety net and enhancing targeting of } \\
\text { social assistance. } \\
\text { 2. Policy note on civil service reform. } \\
\text { 3. Policy note on parastatal reform and privatization. } \\
\text { 4. Strategy on improving business environment and promoting } \\
\text { private sector investment }\end{array}$ & $\begin{array}{l}\text { TBD } \\
\text { TBD } \\
\text { TBD } \\
\text { TBD }\end{array}$ & $\begin{array}{l}\text { February-March } \\
2009 \\
\\
\text { June } 2009 \\
\text { June } 2009 \\
\text { June } 2009\end{array}$ \\
\hline \multicolumn{4}{|c|}{ C. Agreement on joint products and missions } \\
\hline \begin{tabular}{|l|} 
Joint \\
products
\end{tabular} & $\begin{array}{l}\text { Joint mission to discuss a medium-term structural reform agenda } \\
\text { focusing on: social safety net targeting; civil service reform, } \\
\text { parastatal reform; and promoting private sector investment }\end{array}$ & $\begin{array}{l}\text { May } 2009 \\
\text { (preliminary) }\end{array}$ & $\begin{array}{l}\text { August } 2009 \\
\text { (preliminary) }\end{array}$ \\
\hline
\end{tabular}




\title{
III. SEyChelles: Relations With THE AFriCAN DeVElopMent BANK GROUP
}

\author{
(As of October 2008)
}

The African Development Bank Group commenced operations with the Republic of Seychelles in 1978 and has since approved 19 operations comprising 15 projects, one study and three lines of credit for the country. Cumulative approvals as of October 2008 (there were no approvals between 2001 and 2006 when the country was under sanctions) amounted to UA 84.87 million, ${ }^{1}$ of which 73 percent was from the African Development Bank (ADB), 14 percent from the Nigeria Trust Fund (NTF), and the remaining 13 percent from the African Development Fund (ADF) (Table 1). Reflecting government priorities, most of the operations were in the social sector (46 percent). This was followed by the financial sector (16 percent), agricultural sector (15 percent), transportation (13 percent), water supply and sanitation (10 percent) and industrial sector (1 percent). Before sanctions were imposed, about 76.8 percent of the total commitments on all approved loans had been disbursed and the balance of 23.2 percent was cancelled after sanctions were applied.

The country was under sanctions with the African Development Bank Group since February 16, 2000 due to the arrears situation. On October 6, 2006 the Seychelles authorities made a payment of US\$ 40 million as a first installment towards the clearance of its arrears owed to the African Development Bank Group and paid the balance of US\$ 6.75 million on November 14, 2006. The African Development Bank Group consequently lifted all sanctions and started discussions on possible reengagement with the country. Unfortunately, progress was limited because from the second half of 2007 the country occasionally experienced difficulties in meeting its obligations and intermittently slipped back into arrears. Seychelles is now current on its obligations and an agreement has been reached with the government for a joint ADB-World Bank reengagement strategy.

In the interim, the African Development Bank Group has been focusing on the possibilities for the country to access grant resources, such as those available under the African Water Facility and the Middle Income Countries' (MIC) Technical Assistance Fund. Under the African Water Facility, a grant amounting to $€ 955,000$ was signed in May 2008 to finance the preparation of the Water Development Plan aimed at improved water management and governance, and identifying priority investment projects for funding, in order to meet Seychelles' water needs up to 2030. The study is expected to be completed by December 2009. In addition, two proposals that the Government has submitted for consideration under the MIC Technical Assistance Fund are being processed. One request for a grant amounting to UA 600,000 aims mainly to support human resource development, training and capacity building as well as the establishment of the Seychelles University Foundation. The other request is for a grant amounting to US\$ 500,000 to finance studies for a Submarine Cable System to link Seychelles to East Africa.

\footnotetext{
${ }^{1}$ UA $1=$ US\$ 1.55722 as at October 27, 2008.
} 


\section{Seychelles: Relations with the African Development Bank Group}

Table 1. Operations Summary as at 15 October, 2008

Operations since: 1978

Total Number of Operations 19: 15 Projects, 1 Study, 3 Lines of Credit

\begin{tabular}{lrrrr}
\hline $\begin{array}{l}\text { Source of } \\
\text { Financing }\end{array}$ & $\begin{array}{c}\text { Commitments } \\
\text { (UA mission) }\end{array}$ & $\begin{array}{c}\text { Percentage } \\
\text { Share }\end{array}$ & $\begin{array}{c}\text { Disbursed } \\
\text { Amount } \\
\text { (UA mission) }\end{array}$ & $\begin{array}{c}\text { Percentage } \\
\text { Disbursed }\end{array}$ \\
\hline ADB & 62.19 & 73 & 44.12 & 70.9 \\
ADF/TAF & 10.68 & 13 & 10.68 & 100.0 \\
NTF & 12.00 & 14 & 10.39 & 86.6 \\
\hline Total & 84.87 & 100 & 65.19 & 76.8 \\
\hline
\end{tabular}




\section{SEyChelles: Statistical ISSUES}

Data provision has some shortcomings, but it is broadly adequate for surveillance. The country is participating in the General Data Dissemination System (GDDS) and government finance statistics modules of the Anglophone Africa project funded by the U.K. Department for International Development (DFID). The country has participated in the GDDS since December 2006. Despite recent efforts to improve statistical capacity, the country will likely require sustained technical assistance and additional resources for statistical development over the medium term in order to significantly improve the quality of economic statistics.

\section{Real sector statistics}

National accounts data are prepared on a calendar-year basis with 1986 serving as the base year for constant price measures. In February 2008, the National Statistics Bureau published new provisional national accounts estimates for 2004-2007 with 2006 as the base year. The overall level of GDP was revised up by 25 percent in current prices due to improved coverage and methodology. Further revisions are planned for late 2008 or early 2009. There are considerable delays in compiling and disseminating volume measures of GDP.

Tourism statistics are compiled on a weekly and monthly basis. Production indicators are compiled quarterly, and both are reported to the IMF in a timely manner.

Data on average earnings and employment by sector are collected on a quarterly basis by the National Statistics Bureau, but there are no data on unit labor costs. The central bank publishes a monthly estimate of the unemployment rate.

The consumer price index (CPI) utilizes expenditure weights derived from the household budget survey of May 2006-July 2007. The base period is July 2007. Prices are collected on or around the $15^{\text {th }}$ of every month.

\section{Government finance statistics}

Government finance statistics are recorded on a cash basis broadly consistent with the Government Finance Statistics Manual (1986). The authorities have participated in a GFS pilot study that presented government finance statistics in the GFSM 2001 analytic framework and are currently participating in a DFID financed technical assistance project. The project - as follow-up to the pilot study - aims at improving the cash-based statistics for operational and reporting purposes while also laying the foundations for the implementation of accrual-based measures of fiscal performance and extending the institutional coverage to include nonfinancial public corporations.

Annual data on consolidated central government transactions are reported for publication in the Government Finance Statistics Yearbook (GFSY). The authorities have recently prepared 
cash data on central government budgetary operations for publication in the IFS using the GFSM 2001 Statement of Sources and Uses of Cash.

\section{Monetary and financial statistics}

Monetary data are reported regularly to STA for publication in the IFS. The analytical framework underlying the compilation of monetary statistics is generally sound. An integrated monetary database has been developed and is fully operational using the standardized report forms (SRF) for reporting monetary data to the Fund. The SRF-based monetary data have been published in the IFS Supplement since its March 2007 issue.

\section{External sector statistics}

The authorities have made substantial progress in adopting the methodology of the fifth edition of the Balance of Payments Manual. Trade data are reported on a quarterly basis, but with some delay. Balance of payments data are reported to the Statistics and African Departments generally nine months after the reference period, but provisional estimates are provided to missions seven months after the reference period.

The quality of balance of payments data is impaired by the operations of the foreign exchange parallel market, which divert transactions away from the banking system and into the informal sector. Since the hiring of financial advisors, considerable progress has been made recently in collecting and updating data on public sector external debt and debt-service and external payments arrears. 


\section{SEYCHELLES: TABLE OF COMMON INDICATORS REQUIRED FOR SURVEILLANCE}

(As of October 30, 2008)

\begin{tabular}{|c|c|c|c|c|c|}
\hline & $\begin{array}{c}\text { Date of } \\
\text { latest } \\
\text { observation }\end{array}$ & $\begin{array}{c}\text { Date } \\
\text { received }\end{array}$ & $\begin{array}{c}\text { Frequency } \\
\text { of } \\
\text { Data }^{6}\end{array}$ & $\begin{array}{l}\text { Frequency } \\
\text { of } \\
\text { Reporting }^{6}\end{array}$ & $\begin{array}{l}\text { Frequency } \\
\text { of } \\
\text { publication }^{6}\end{array}$ \\
\hline Exchange Rates & $10 / 24 / 08$ & $10 / 24 / 08$ & Daily & Daily & Daily \\
\hline $\begin{array}{l}\text { International Reserve Assets and Reserve } \\
\text { Liabilities of the Monetary Authorities }{ }^{1}\end{array}$ & 06/30/08 & $08 / 06 / 08$ & Daily & Daily & Daily \\
\hline Reserve/Base Money & Aug. 08 & $10 / 24 / 08$ & Monthly & Monthly & Monthly \\
\hline Broad Money & Aug. 08 & $10 / 24 / 08$ & Monthly & Monthly & Monthly \\
\hline Central Bank Balance Sheet & Aug. 08 & $10 / 24 / 08$ & Monthly & Monthly & Monthly \\
\hline $\begin{array}{l}\text { Consolidated Balance Sheet of the Banking } \\
\text { System }\end{array}$ & Aug. 08 & $10 / 24 / 08$ & Monthly & Monthly & Monthly \\
\hline Interest Rates $^{2}$ & $10 / 24 / 08$ & $10 / 24 / 08$ & Weekly & Weekly & Weekly \\
\hline Consumer Price Index & $09 / 31 / 08$ & $10 / 21 / 08$ & Monthly & Monthly & Monthly \\
\hline $\begin{array}{l}\text { Revenue, Expenditure, Balance and } \\
\text { Composition of Financing }{ }^{3}-\text { Central } \\
\text { Government }\end{array}$ & Sept. 08 & $10 / 16 / 08$ & Monthly & Monthly & Monthly \\
\hline $\begin{array}{l}\text { Stocks of Central Government and Central } \\
\text { Government-Guaranteed Domestic Debt }\end{array}$ & $08 / 31 / 08$ & $09 / 15 / 08$ & Monthly & Monthly & Quarterly \\
\hline External Current Account Balance & $06 / 30 / 08$ & $09 / 15 / 08$ & Quarterly & Quarterly & Quarterly \\
\hline Exports and Imports of Goods and Services & $03 / 31 / 08$ & $09 / 30 / 07$ & Monthly & Irregular & Irregular \\
\hline GDP/GNP & $12 / 31 / 07$ & 03/03/08 & Annual & Annual & Irregular \\
\hline Gross External Debt & $08 / 31 / 08$ & $09 / 15 / 08$ & Monthly & Monthly & Irregular \\
\hline International Investment Position ${ }^{6}$ & $\ldots$ & $\ldots$ & NA & NA & NA \\
\hline
\end{tabular}

${ }^{1}$ Includes reserve assets pledged or otherwise encumbered as well as net derivative positions.

${ }^{2}$ Both market-based and officially determined, including discount rates, money market rates, rates on treasury bills, notes and bonds.

${ }^{3}$ Foreign, domestic bank, and domestic nonbank financing.

${ }^{4}$ The general government consists of the central government (budgetary funds, extra budgetary funds, and social security funds) and state and local governments.

${ }^{5}$ Including currency and maturity composition.

${ }^{6}$ Includes external gross financial asset and liability positions vis-à-vis nonresidents.

${ }^{7}$ Daily (D), Weekly (W), Monthly (M), Quarterly (Q), Annually (A), Irregular (I); or Not Available (NA). 


\title{
INTERNATIONAL MONETARY FUND
}

\section{Seychelles-Staff Report for the 2008 Article IV Consultation and Request for a Stand-By Arrangement Supplementary Information}

\author{
Prepared by the staff of the African Department \\ (in consultation with other departments) \\ Approved by Mark Plant (AFR) and Philip Gerson (SPR)
}

November 12, 2008

This supplement reports on economic and policy developments since the staff report was finalized. The staff appraisal remains unchanged.

1. A number of major program reforms became effective on November 1, 2008. The main components of the program were outlined by President Michel in a speech to the nation on October 31 and have been well received by the business community. The population had been prepared through an extensive information campaign, and the changes were for the most part widely anticipated.

- $\quad$ The national assembly approved laws to remove all controls on foreign exchange and market float of the rupee on October 31. On the first trading day (November 3), the rupee depreciated by about 37 percent against the U.S. dollar, in line with expectations. Exchange rates were highly variable during the first week, but there were no major runs on the currency. As of November 11 the rupee had depreciated a further 12 percent (Figure 1). The authorities are processing over 20 requests to license foreign exchange bureaus, which are critical to making the foreign exchange market competitive. Fund technical assistance has been helping the authorities with the Figure 1. Seychelles: T-Bill and Exchange Rate Developments (The rupee against major currencies; T-bill rate (tender issue, 91 days); Oct. to Nov. 2008)

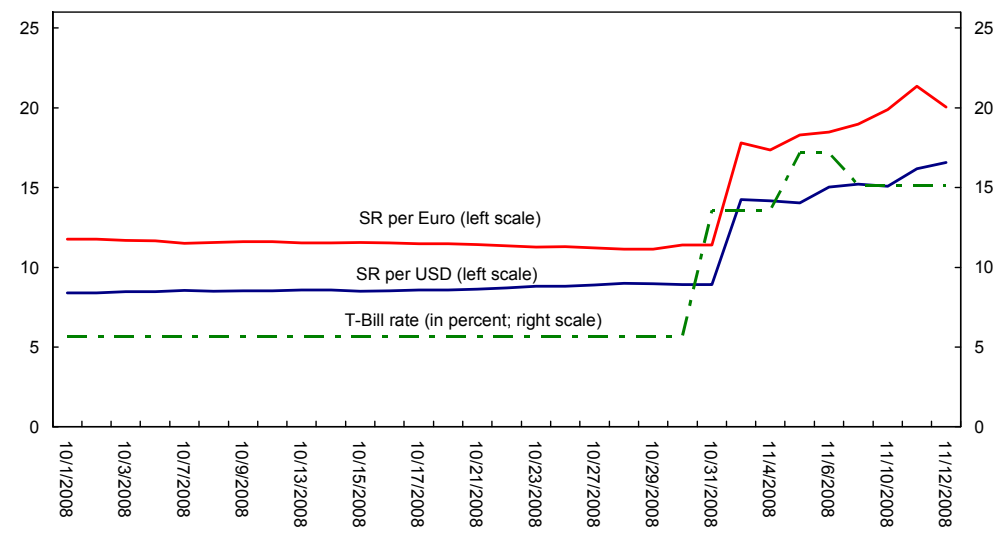
transition and with drafting market arrangements. 
- Indirect product subsidies were eliminated, and the National Assembly approved the creation of the agency on welfare, responsible to implement a targeted social safety net. The safety net is essential to the authorities' strategy to mitigate the impact of the reforms on the population. The President also announced a graduated public sector wage increase that is below the rate of inflation and a series of programmed revenue measures.

- $\quad$ The Central Bank of Seychelles (CBS) announced that domestic price stability will be the policy objective of the central bank. The nascent interbank market for deposits at the central bank and for treasury bills has begun and interest rates are rising (Table 1). Interest rates will need to rise further in coming weeks to positive real levels to support the new policy framework. A new CBS Governor, a former Fund staff member, was appointed on November 1 after the incumbent resigned. As the safeguards mission recommended, the CBS has tendered for an external audit that meets international audit standards and expects to finalize contract discussions shortly.

\begin{tabular}{|c|c|c|c|c|c|c|c|c|}
\hline \multicolumn{9}{|c|}{ Table. Seychelles: Interest Rates, September-November 2008} \\
\hline \multicolumn{9}{|c|}{ Treasury Bills (weekly auction results; average tender rate in percent) } \\
\hline Maturity period & 23-Sep & 3 -Oct & 10 -Oct & $17-$ Oct & 24-Oct & $31-$ Oct & 5 -Nov & $7-\mathrm{Nov}$ \\
\hline 91 days & 5.9 & 8.7 & 10.2 & 10.2 & 10.5 & 13.6 & 17.2 & 15.1 \\
\hline \multicolumn{9}{|c|}{ Deposit Auction Arrangement (weighted average DAA rate in percent) } \\
\hline Maturity periods & 22-Sep & $1-\mathrm{Oct}$ & 8 -Oct & 15-Oct & 22 -Oct & $29-$ Oct & 5 -Nov & $12-\mathrm{Nov}$ \\
\hline 7 days & 5.3 & 5.7 & 7.4 & 8.2 & 8.6 & 9.4 & 9.5 & 9.9 \\
\hline 14 days & 5.1 & 6.8 & 7.1 & 8.6 & 9.6 & 11.0 & 11.1 & n.a. \\
\hline 28 days & 5.3 & 7.7 & 7.8 & n.a. & 10.4 & 11.6 & 11.8 & n.a. \\
\hline
\end{tabular}

\section{Program financing assurances have been received from Paris Club creditors for} the Stand-By Arrangement. In view of Seychelles' unsustainable debt situation, and in accordance with the principles of the Evian approach, creditors also confirmed their commitment to consider a debt stock reduction at some appropriate time in the future.

3. The authorities are beginning discussions with other creditors. The authorities and their financial advisors will commence a round of meetings with private creditors in Europe and the Middle East in the week of November 17, 2008. They have also begun discussions with non-Paris Club official creditors. 
4. In a move to strengthen governance, the President and each member of cabinet signed and submitted declarations of their assets to the ethics commission on November 5, as the 2008 Public Officers' Ethics Act requires.

5. Recent economic developments are generally as projected.

- $\quad$ Real sector developments suggest a deceleration in tourism. While tourism spending for the first six months was up 39 percent over the same period in 2007, in the third quarter, it was down by 37 percent compared to 2007.

- $\quad$ Inflation eased in September to 34.2 percent as energy prices declined.

- $\quad$ Data through end-September reveal a better fiscal outturn than projected. The nine month primary surplus was 5.8 percent of GDP compared to a projected 5.3 percent, largely because tax revenues were higher than expected.

- $\quad$ Monetary indicators are in line with the program. Reserve money growth has been contained, and foreign reserves are above the end-2008 performance criterion floor.

6. Staff welcomes the decisive implementation of the bold and difficult reform measures by the authorities, which bodes well for the success of the program. 


\section{IMF Executive Board Concludes 2008 Article IV Consultation with Seychelles}

On November 14, 2008, the Executive Board of the International Monetary Fund (IMF) concluded the Article IV consultation with Seychelles. ${ }^{1}$

\section{Background}

Seychelles is in the midst of an acute balance of payments and public debt crisis, which jeopardizes its high living standards and economic development. Despite step devaluations in 2006-07, the exchange rate has not been consistent with economic fundamentals for some years. Competitiveness has been undermined by expansionary fiscal and monetary policies inconsistent with the maintenance of the pegged exchange rate regime. External debt rose to unsustainable levels, complex exchange controls and restrictions were progressively introduced and foreign exchange shortages ensued. A parallel foreign exchange market flourished and dollarization rose.

Reform efforts since 2003 have brought about some fiscal adjustment, trade reform and partial economic liberalization, but have been insufficient to address longstanding macroeconomic imbalances and vulnerabilities. In mid-2008, facing the near exhaustion of official foreign reserves, the authorities missed a payment on a privately-placed external debt issue in July and on a Eurobond payment in October. Standard and Poor's has downgraded Seychelles to SD (selective default).

\footnotetext{
${ }^{1}$ Under Article IV of the IMF's Articles of Agreement, the IMF holds bilateral discussions with members, usually every year. A staff team visits the country, collects economic and financial information, and discusses with officials the country's economic developments and policies. On return to headquarters, the staff prepares a report, which forms the basis for discussion by the Executive Board. At the conclusion of the discussion, the Managing Director, as Chairman of the Board, summarizes the views of Executive Directors, and this summary is transmitted to the country's authorities.
} 
The oil and food price shocks, together with the global slowdown, have exacerbated vulnerabilities. GDP growth, which has been strong since 2005 on account of high hotel-related foreign direct investment (FDI) and tourism receipts, is projected to sharply decline in 2008 due to foreign exchange shortages and less buoyant tourism growth. Inflation has risen rapidly following the increase in world food and fuel prices and the 2006-07 devaluations. The external current account deficit is projected to widen due to lower growth in tourism receipts, the petroleum and food price shock, and higher costs of transportation services. As of mid-October, official reserves had fallen to very low levels and the balance of payments is increasingly financed by external arrears accumulation. In light of these developments, in 2008 the authorities began to tighten fiscal and monetary policy.

The authorities have requested Fund assistance in support of a comprehensive reform strategy aimed at restoring internal and external balances. The reforms include a fundamental liberalization of the exchange regime, involving the elimination of all exchange restrictions and a float of the rupee; a significant and sustained tightening of fiscal policy backed by a reduction in public employment and the replacement of indirect subsidies with a targeted social safety net; a reform of the monetary policy framework to focus on liquidity management based on indirect instruments; and a reduction in the role of the state in the economy to boost private sector development, through further privatization, enhanced fiscal governance, and a review of the tax regime.

Although the authorities' proposed fiscal adjustment is heavily frontloaded and sustained over several years, a comprehensive debt restructuring involving a substantial reduction in the debt service burden consistent with Seychelles' long-term ability to pay will be needed to place public debt on a sustainable path. At almost 151 percent of GDP, public debt is unsustainable. External public debt represents some 95 percent of GDP (US\$808 million), of which over 40 percent is arrears, mostly to Paris Club creditors and on the private placement. There is a small amount of arrears to multilateral creditors. Following the missed payments on commercial obligations, the authorities announced that they had hired qualified financial and legal advisors and that they would approach creditors to seek an agreement on a comprehensive debt restructuring, consistent with their ability to pay.

\section{Executive Board Assessment}

Seychelles faces a severe economic crisis-characterized by large fiscal and balance of payments imbalances built up over several years, an unsustainable public debt burden, mounting arrears, and dwindling foreign reserves - which has been exacerbated by the global economic turmoil. Executive Directors accordingly welcomed the authorities' determination to undertake far-reaching economic reforms aimed at putting the economy back on the track of sustainable economic growth and development. This reform effort merits the support of the international community, including through comprehensive public debt restructuring.

Directors commended the authorities' upfront liberalization of the exchange regime and the float of the rupee. The removal of extensive exchange restrictions and discretionary regulations as part of the reform program is essential to restore credibility of the currency and unify the parallel and official exchange rates. Several Directors emphasized that, at this juncture, there is little 
alternative to a floating market-determined exchange rate regime, especially as official reserves are largely depleted. However, further reflection will be required on the best long-run monetary policy framework and exchange rate regime for Seychelles.

Directors saw the significant tightening of fiscal policy in 2008 as a crucial element of macroeconomic stabilization, and welcomed the accompanying provision of targeted support for the most vulnerable groups. Key to program success will be the implementation of strong fiscal policy reforms needed to maintain sizable primary surpluses over the medium term. These include introduction of a targeted social safety net to replace indirect product subsidies and tax exemptions and continuation of the public sector employment retrenchment exercise.

The public debt of Seychelles is unsustainable, even with the significant fiscal adjustment envisaged. Directors welcomed the authorities' good faith efforts to work with official bilateral and commercial creditors on a debt restructuring strategy aimed at reestablishing public debt sustainability consistent with Seychelles' long-term payment capacity, based on the principles of transparency, inter-creditor equity, and open dialogue with all creditor groups. They underlined the importance of steps to strengthen public debt management. Directors looked forward to a more comprehensive Debt Sustainability Analysis (DSA) to be provided at the time of the first review of the stand-by arrangement as well as to regular updates on financing assurances and safeguards.

Directors welcomed the major strengthening of the monetary policy framework under way, notably in enhancing the ability of the Central Bank of Seychelles (CBS) to manage liquidity through indirect market-based monetary intervention. This will require closer collaboration between the CBS and Ministry of Finance to improve liquidity forecasting and management. Directors supported the authorities' efforts to strengthen financial sector supervision, and noted that the budget includes a provision for the potential recapitalization needs of the sector.

Directors commended the authorities for taking several important measures to bolster public sector governance and transparency, and encouraged the authorities to address all areas of concern identified in the safeguards assessment. Steps to address weaknesses in data quality and timeliness with technical assistance from the Fund will also be important.

Directors recognized that a comprehensive and sustained structural reform effort will be needed to underpin economic growth and competitiveness over the medium term, and welcomed the authorities' intention to articulate such a medium-term structural reform agenda in 2009 with input from the Fund, the World Bank, and other partners.

Public Information Notices (PINs) form part of the IMF's efforts to promote transparency of the IMF's views and analysis of economic developments and policies. With the consent of the country (or countries) concerned, PINs are issued after Executive Board discussions of Article IV consultations with member countries, of its surveillance of developments at the regional level, of post-program monitoring, and of ex post assessments of member countries with longer-term program engagements. PINs are also issued after Executive Board discussions of general policy matters, unless otherwise decided by the Executive Board in a particular case. 
Seychelles: Selected Economic and Financial Indicators, 2005-08

\begin{tabular}{|c|c|c|c|c|}
\hline & 2005 & 2006 & 2007 & $\begin{aligned} 2008 \\
\text { Est. }\end{aligned}$ \\
\hline & \multicolumn{4}{|c|}{$\begin{array}{c}\text { (Annual percentage change, unless } \\
\text { otherwise indicated) }\end{array}$} \\
\hline \multicolumn{5}{|l|}{ National income and prices } \\
\hline Nominal GDP (in millions of Seychelles rupees) & 4,861 & 5,342 & 6,113 & 7,878 \\
\hline Real GDP & 7.5 & 8.3 & 7.3 & 3.1 \\
\hline \multirow[t]{2}{*}{ Retail price index ${ }^{1}$} & 0.8 & -1.4 & 5.7 & 32.2 \\
\hline & \multicolumn{4}{|c|}{$\begin{array}{l}\text { Annual change in percent of beginning-of- } \\
\text { period broad money, unless otherwise } \\
\text { indicated) }\end{array}$} \\
\hline \multicolumn{5}{|l|}{ Money and credit } \\
\hline Domestic credit & 1.8 & -9.6 & 8.9 & 6.2 \\
\hline Broad money (M2(p)) ${ }^{2}$ & 1.7 & 3.0 & -14.9 & 2.6 \\
\hline Reserve Money ${ }^{3}$ & 3.4 & 32.7 & -23.1 & 3.4 \\
\hline \multirow[t]{2}{*}{ Interest rate (average during period, 91-day bill) } & 2.8 & 3.2 & 3.6 & $\ldots$ \\
\hline & \multicolumn{4}{|c|}{ (Percent of GDP) } \\
\hline \multicolumn{5}{|l|}{ Savings and investment } \\
\hline Gross national savings & 14.6 & 14.2 & 9.1 & 4.9 \\
\hline Gross investment & 34.3 & 28.1 & 32.5 & 33.6 \\
\hline \multicolumn{5}{|l|}{ Government budget } \\
\hline Total revenue, excluding grants & 41.1 & 42.0 & 35.9 & 35.4 \\
\hline Identified expenditure and net lending & 40.4 & 49.6 & 46.0 & 37.6 \\
\hline Current expenditure & 35.1 & 41.5 & 40.8 & 32.2 \\
\hline Capital expenditure and net lending & 5.3 & 8.0 & 5.1 & 5.4 \\
\hline Overall balance, including grants (above the line) & 1.7 & -6.2 & -9.8 & -1.8 \\
\hline Primary balance & 7.3 & -0.6 & -2.3 & 7.1 \\
\hline Total public debt ${ }^{4}$ & 147.1 & 139.5 & 146.0 & 151.3 \\
\hline Domestic & 100.5 & 85.8 & 74.1 & 53.5 \\
\hline External & 46.6 & 53.7 & 71.9 & 97.8 \\
\hline \multicolumn{5}{|l|}{ External sector } \\
\hline \multirow[t]{2}{*}{ Current account balance after official transfers } & -19.7 & -13.9 & -23.4 & -28.8 \\
\hline & \multicolumn{4}{|c|}{ (US\$ millions, unless otherwise indicated) } \\
\hline Gross official reserves (end of year) & 56.1 & 112.7 & 9.8 & 18.7 \\
\hline In months of imports, c.i.f. & 0.7 & 1.3 & 0.1 & 0.2 \\
\hline In percent of broad money & 6.3 & 13.0 & 8.0 & 35.0 \\
\hline
\end{tabular}

Sources: Central Bank of Seychelles; Ministry of Finance; and staff estimates and projections.

${ }^{1}$ Annual averages. The official retail price index is believed to understate substantially the rate of inflation.

${ }^{2}$ M2 plus domestic currency balances earmarked for pending import requests ("pipeline").

${ }^{3}$ In annual percentage change.

${ }^{4}$ Including arrears. 
Press Release No. 08/282

International Monetary Fund

FOR IMMEDIATE RELEASE

Washington, D.C. 20431 USA

November 14, 2008

\section{IMF Executive Board Approves US\$26 Million Stand-By Arrangement for Seychelles}

The Executive Board of the International Monetary Fund (IMF) today approved a two-year Stand-By Arrangement (SBA) to support Seychelles' bold economic reform effort, with total access equivalent to SDR 17.6 million (about US\$26.1 million). An amount equivalent to SDR 6.16 million (about US\$9.13 million) will be made available immediately. The balance will be disbursed in seven quarterly installments over the next two years, subject to the Executive Board's reviews of performance under the arrangement.

Following the Executive Board's discussion on the Seychelles, Mr. Takatoshi Kato, Deputy Managing Director and Acting Chairman, made the following statement:

"The Seychelles authorities are to be commended for their strong commitment to, and good start in, implementing a far-reaching reform program to address the macroeconomic imbalances that have built up over the past decades.

“The authorities' fundamental liberalization of the exchange regime, involving the elimination of all exchange restrictions and a float of the rupee, is a critical reform step to address the underlying causes of the balance of payments crisis. The availability of foreign exchange at a market-determined price should, in due time, facilitate a rebound of economic activity. In the near term, however, activity is likely to be subdued due to both the necessary domestic adjustment effort as well as the worsening international outlook.

“The authorities' reform program includes a marked tightening of fiscal policy, but leaves significant room for targeted social programs. Strong fiscal policy reforms, including the removal of tax exemptions and strengthening of public financial management, need to be sustained in order to secure substantial primary surpluses over the medium term. The public sector employment retrenchment exercise, together with the replacement of indirect product subsidies by a targeted social safety net, are important reform components.

"Even with the significant fiscal tightening envisaged, Seychelles' public debt would remain unsustainable. Good faith negotiations with official bilateral and commercial external 
creditors are critical in order to secure a debt restructuring aimed at reestablishing public debt sustainability, consistent with Seychelles' long-term payment capacity.

"The Central Bank of Seychelles (CBS) has strengthened its ability to manage liquidity, through the introduction of indirect market-based instruments. The program includes measures to contain the risks to the financial system by bolstering supervision and a fiscal provision for potential recapitalization needs by state-owned financial institutions.

"The comprehensive and bold nature of the authorities' reform program merits the support of the international community. While there are risks to the program, including from a global downturn, the early and important policy reforms the authorities have already undertaken are indicative of their strong ownership of the reform effort," Mr. Kato said. 


\section{Background and Program Summary}

Seychelles is in the midst of an acute balance of payments and public debt crisis, which jeopardizes the population's living standard and the country's economic development.

Large macroeconomic imbalances and vulnerabilities resulting from longstanding unsustainable macroeconomic policies, combined with recent external shocks, culminated in mid-2008 with the near-exhaustion of foreign reserves and missed payments on public debt obligations. Growth is declining and inflation has risen sharply. The exchange rate was pegged at a level incompatible with fundamentals. In combination with a complex system of exchange restrictions and controls this resulted in economic dislocation, a parallel exchange market, and pervasive dollarization of the domestic economy.

The authorities have requested Fund assistance in support of a comprehensive reform program. Acknowledging that past reform efforts have been insufficient to address imbalances and vulnerabilities, the authorities have begun implementing a package of major macroeconomic and structural reforms, including:

- A fundamental liberalization of the exchange regime, involving the elimination of all exchange restrictions and a float of the rupee was introduced in early November;

- $\quad$ A significant and sustained tightening of fiscal policy backed by a reduction in public employment and the replacement of indirect subsidies by a targeted social safety net;

- $\quad$ A reform of the monetary policy framework to focus on liquidity management based on indirect instruments; and

- A reduction in the role of the state in the economy to boost private sector development, through further privatization, enhanced fiscal governance, and a review of the tax regime.

However, to close external financing gaps and put public debt on a sustainable path, these strong reform efforts will need to be complemented by a comprehensive public debt restructuring, involving a substantial reduction in public debt service obligations over the long term to levels consistent with the country's payments capacity.

The reforms are heavily frontloaded, with the bulk of the fiscal adjustment and other key measures implemented in the fourth quarter of 2008. The projected turnaround in the primary fiscal balance from 2007 amounts to about 8 percent of GDP in 2008, with sustained annual primary surpluses of about $6 \frac{1}{2}$ percent through 2011 . Fiscal reforms also include the removal of tax exemptions, a strengthening of tax administration and public financial management. 
Seychelles: Selected Economic and Financial Indicators, 2005-08

\begin{tabular}{l}
\hline \\
National income and prices \\
Nominal GDP (in millions of Seychelles rupees) \\
Real GDP \\
Retail price index ${ }^{1}$
\end{tabular}

Money and credit

Domestic credit

Broad money $(\mathrm{M} 2(\mathrm{p}))^{2}$

Reserve Money ${ }^{3}$

Interest rate (average during period, 91-day bill)

Savings and investment

Gross national savings

Gross investment

$\begin{array}{rrrr}14.6 & 14.2 & 9.1 & 4.9\end{array}$

$\begin{array}{llll}34.3 & 28.1 & 32.5 & 33.6\end{array}$

Government budget

Total revenue, excluding grants

Identified expenditure and net lending Current expenditure

Capital expenditure and net lending

Overall balance, including grants (above the line)

Primary balance

Total public debt ${ }^{4}$

Domestic

External

$\begin{array}{rrrr}4,861 & 5,342 & 6,113 & 7,878 \\ 7.5 & 8.3 & 7.3 & 3.1 \\ 0.8 & -1.4 & 5.7 & 32.2\end{array}$

Annual change in percent of beginning-ofperiod broad money, unless otherwise indicated)

$\begin{array}{rrrr}1.8 & -9.6 & 8.9 & 6.2 \\ 1.7 & 3.0 & -14.9 & 2.6 \\ 3.4 & 32.7 & -23.1 & 3.4 \\ 2.8 & 3.2 & 3.6 & \ldots\end{array}$

(Percent of GDP)

External sector

Current account balance after official transfers

$\begin{array}{rrrr}41.1 & 42.0 & 35.9 & 35.4 \\ 40.4 & 49.6 & 46.0 & 37.6 \\ 35.1 & 41.5 & 40.8 & 32.2 \\ 5.3 & 8.0 & 5.1 & 5.4 \\ 1.7 & -6.2 & -9.8 & -1.8 \\ 7.3 & -0.6 & -2.3 & 7.1 \\ 147.1 & 139.5 & 146.0 & 151.3 \\ 100.5 & 85.8 & 74.1 & 53.5 \\ 46.6 & 53.7 & 71.9 & 97.8 \\ & & & \\ -19.7 & -13.9 & -23.4 & -28.8\end{array}$

(US\$ millions, unless otherwise indicated)

Gross official reserves (end of year)

$\begin{array}{llll}56.1 & 112.7 & 9.8 & 18.7\end{array}$

In months of imports, c.i.f.

$\begin{array}{llll}0.7 & 1.3 & 0.1 & 0.2\end{array}$

In percent of broad money

$\begin{array}{llll}6.3 & 13.0 & 8.0 & 35.0\end{array}$

Sources: Central Bank of Seychelles; Ministry of Finance; and staff estimates and projections.

${ }^{1}$ Annual averages. The official retail price index is believed to understate substantially the rate of inflation.

${ }^{2}$ M2 plus domestic currency balances earmarked for pending import requests ("pipeline").

${ }^{3}$ In annual percentage change.

${ }^{4}$ Including arrears. 


\section{Statement by Christopher Legg, Executive Director for Seychelles and Simon Duggan, Advisor to Executive Director November 14, 2008}

\section{Background}

Following independence in 1976, Seychelles pursued a development model centered around the creation of a social welfare state that successfully raised standards of health, education and housing to amongst the best in Africa. While successful in raising social capital and per capita income, this development model became financially unsustainable, with achievements in social development increasingly funded through the accumulation of public debt at commercial rates.

In 2003 the Government embarked on a reform and modernization effort (the Macro-Economic Reform Program) that promoted Seychelles' transition toward a market-based economy, and in 2007 launched a strategy (Seychelles Strategy 2017) for doubling nominal per capita income and achieving a substantial reduction in public sector debt. By early 2008 achievements included: a large fiscal adjustment; the removal of most universal subsidies; privatization of many state-owned enterprises; and a substantial reduction in the pegged exchange rate (from 5.5 to 8 rupees to the US dollar over a 12-month period). These reforms had some success, with economic growth averaging above 7 per cent from 2005 to 2007. The pace of reform was not sufficient, however, to address the magnitude of Seychelles' macroeconomic imbalances, so vulnerabilities remained high.

In the midst of this transition, Seychelles has been hit very hard by the food and fuel crisis and global slowdown, exposing economic fragilities and placing enormous pressure on Seychelles' external position. Inflation has risen to over 35 per cent, foreign exchange shortages intensified and economic growth slowed abruptly. As a percentage of GDP, Seychelles' current account deficit has doubled from 14 per cent in 2006 to a projected 29 per cent in 2008, driven by higher global food and fuel prices and lower tourism earnings due to the slowdown in Europe. Seychelles' overall balance of payments position has deteriorated from a small surplus in 2007 to a substantial deficit in 2008, funded through a reduction in foreign exchange reserves and increased arrears to both official and commercial creditors. Seychelles' debt and balance of payments crisis came to a head in July 2008 when the Government missed a payment due on a privately-placed external debt issue, and in October 2008 when the Government was unable to make a coupon payment on a Eurobond, prompting Standard and Poor's to downgrade Seychelles to SD (Selective Default).

Seychelles' Minister of Finance, Mr. Danny Faure, wrote to the Managing Director at the end of June 2008 requesting an IMF-supported program. The support provided by Fund staff since that time on the design of Seychelles' economic reform program has been outstanding. Following open and constructive dialogue with Fund staff, Seychelles is now seeking a two-year Stand-By Arrangement to support a comprehensive reform program directed at achieving macroeconomic and sustainable private sector led growth. 


\section{Economic Reform Program}

The key pillars of the Government's economic reform program are: full liberalisation of the exchange regime; a significant tightening of fiscal policy; tighter monetary policy under a new market-based operating framework; the replacement of universal subsidies with a targeted social safety net; and a smaller and more efficient public service. The Government has substantively put these reforms in place - a tangible demonstration of their resolve - and is committed to taking additional measures as necessary to achieve program objectives.

\section{Exchange Regime and Exchange Rate Policy}

Seychelles' external vulnerabilities are manifested in a misaligned exchange rate, sustained by pervasive foreign exchange restrictions. Lack of confidence in the rupee has fostered an active parallel market. In 2007 the Central Bank of Seychelles (CBS) started to gradually remove exchange restrictions, shifting foreign exchange dealing to the commercial banks and allowing individuals to open foreign exchange accounts. While these were important steps in the right direction, extensive restrictions remained - including a system of foreign exchange retention and rationing operated by the CBS at the official rate to ensure that essential foreign exchange needs could be met - and excess demand for foreign currency persisted at the official exchange rate.

The CBS reduced the pegged exchange rate by 45 per cent against the SUS over the 12 months to October 2007; however, most restrictions remained in place and the nominal depreciation was compromised by loose liquidity conditions and increased spending by state-owned enterprises, including to fund a doubling of Seychelles' fuel import bill, adding to inflationary pressures and undermining competitiveness gains.

With a very low level of foreign exchange reserves, limited external financing options and large external debt obligations, the Government concluded that a pegged exchange rate regime was no longer viable. Therefore, on 1 November 2008 Seychelles eliminated all foreign exchange controls and floated the rupee. On the day of the float, the exchange rate depreciated from 8.9 rupees to the US dollar to around 15 - broadly in line with the previous parallel market rate. Consistent with international best-practice, the CBS will operate in the foreign exchange market to avoid excessive volatility, meet the Government's foreign exchange needs and accumulate international reserves over time, but will not seek to influence the exchange rate level.

The Government and CBS are committed to supporting the float through tightened fiscal and monetary policy, thereby minimizing over-shooting of the exchange rate, reducing second-round inflationary effects and ensuring that nominal exchange rate depreciation translates to increased external competitiveness.

Monetary Policy

Prior to liberalizing the exchange rate, the Central Bank introduced a market-based monetary policy framework directed at establishing price stability through greater 
emphasis on reserve money management. In early-2008 the CBS started actively trading in the secondary market for government securities and in early-October introduced weekly auctions for both Treasury Bills and a central bank deposit facility. Implementation is proceeding well, with T-Bill auctions well-covered, higher domestic interest rates supporting demand for the rupee and a positive yield curve emerging. The CBS is committed to achieving price stability through tighter liquidity conditions and increased interest rates.

The Government and CBS have also been working intensively with public and private financial institutions, both before and after the float, to assist their transition towards the new exchange regime and monetary policy framework. Our authorities are confident that introduction of facilities for trading T-Bills, foreign exchange and deposits at the CBS will promote more efficient liquidity management and support the development of an active inter-bank market.

Seychelles is also committed to addressing risks identified by the IMF's recent safeguards assessment rapidly and comprehensively.

\section{Fiscal Policy}

The Government achieved a significant fiscal tightening in 2008, in line with the Budget announced in December 2007. The primary fiscal balance improved from a 2.3 per cent of GDP deficit in 2007 to an estimated 5.6 per cent of GDP surplus in 2008 (excluding the transfer of valuation gains from the CBS). This is being achieved through a combination of new measures, tight controls on nominal expenditure and revenue buoyancy following a period of high growth and inflation. Nonetheless, the overall fiscal balance is expected to record a $3 \frac{1}{2}$ per cent of GDP deficit in 2008, reflecting scheduled interest payments on public sector debt of around 10 per cent of GDP.

Looking ahead, the Government will maintain primary fiscal surpluses of around 6 $1 \frac{1}{2}$ per cent of GDP in 2009-2010 - even as nominal GDP growth slows - through measures that will improve the structural fiscal position by some 5 percentage points of GDP. The authorities recognise the importance of tightening fiscal policy to support the objectives of the exchange rate float and monetary policy. The Government is also striving to maximize the funds available for debt repayment as it works towards normalizing relations with official and commercial creditors. A comprehensive list of revenue and expenditure measures supporting the fiscal projections are outlined in the authorities' Memorandum of Economic and Financial Policies (MEFP), many of which have already been introduced.

The fiscal position will also be supported by strengthened public financial management, tax administration and public debt management. Following up on the recommendations of a recent IMF public financial management review, the Ministry of Finance is considering options to further rationalise expenditure - including with the assistance of the World Bank - and will implement measures to strengthen budget preparation, implementation and monitoring processes. The Seychelles Revenue Commission has launched tax audits of the 20 largest enterprises and bolstered its capacity. On public debt management, the Government will submit to the National Assembly a Public Debt Law before the end of 2008 
and will formulate a medium-term public debt strategy that complies with the stringent limits on the contracting or guaranteeing of new loans specified under its proposed Stand-By Arrangement.

\section{$\underline{\text { Structural Reforms }}$}

The program's fiscal objectives are supported by the replacement of universal subsidies with a targeted social safety net. The Government has repealed universal product subsidies and is enforcing a cost-recovery policy in the provision of public utilities, thereby eliminating a social welfare system that had been in place for over 20 years. In its place, a Welfare Agency has been established to manage a new system of means-tested income support that will protect the most vulnerable segments of the population while ensuring that incentives to work are maintained. Importantly, the social safety net will be time-limited to guard against welfare dependency. The Government also recently announced a modest increase in the statutory minimum wage, public sector wages and social security benefits, partially offsetting substantial declines over the last two years.

The Government is committed to reforming the public sector to support the fiscal position, boost productivity and promote private sector activity. The public sector accounts for over 50 per cent of the Seychellois workforce, with the government currently engaged in areas that could be more efficiently provided by the private sector. In recent years the Government has privatized a large number of state-owned enterprises and this process will continue. A high-level government taskforce, headed by the Minister of Finance, is conducting a comprehensive review of the range of services provided by the government to achieve further rationalization. Moreover, in late October the Government announced a 12.5 per cent reduction in the public sector workforce by 1 January 2009. This will be achieved primarily through a voluntary departure scheme, supported by a retraining and placement program to assist employees to transition to the private sector. A low unemployment rate and significant importation of labour, primarily in the construction and tourism sectors, provide clear evidence of the private sector's capacity to absorb this cadre of available workers. Through containing public sector wage increases, the reduction in government employees will place downward pressure on the Government's wage bill.

The Government will undertake a fundamental review of the tax system in 2009 that will aim for simplification, a broadening of the tax base and low harmonized tax rates. A number of important measures have already been taken in this direction, including the removal of various GST and income tax exemptions and an adjustment to the GST rate on tourism services. The next step is the removal of all provisions for discretionary exemptions in the Trade Tax and Business Tax Acts from 1 January 2009. With the assistance of the Fund, the Government is aiming to complete the review of the tax system in mid-2009.

\section{International Support}

Policy adjustment on its own will not be sufficient to relieve Seychelles' debt and balance of payments crisis. Closing Seychelles' near term financing gaps and returning future debt service payments to a sustainable level will also require upfront balance of 
payments assistance under an IMF-supported program, debt restructuring and direct financial support from donors.

On 30 September the Government announced that it will seek the support of creditors in the restructuring of around \$US800 million of external debt. Seychelles' public debt is over 150 per cent of GDP, two-thirds of which is external and some \$US313 million is in arrears. With the assistance of legal and financial advisors, the Government is committed to developing a comprehensive debt restructuring strategy focused on the principles of transparency, inter-creditor equity and open dialogue with all creditor groups. As a starting point in this process, approval of an IMF-supported adjustment program will provide the basis for discussions with the Paris Club creditors, who have indicated their willingness to consider Seychelles' debt under an Evian approach.

More broadly, Seychelles will require the assistance of donors to meet its financing needs over the life of the program and to support the investments necessary to place the economy on a sustainable growth path. The authorities welcome the positive signals that they have received from the World Bank and African Development Bank and look forward to engaging the support of bilateral development partners in the near future.

\section{Conclusion}

President Michel announced the Government's economic reform program in an address to the nation on 31 October. The President emphasised in his speech that implementation will be challenging, with recovery from the current economic crisis only possible after a process of substantial adjustment. President Michel also stressed that this is a defining moment in Seychelles' history, highlighting the importance of making a break from the policies of the past and emphasising that strong implementation of the Government's economic reform program will underpin sustained growth and prosperity over the medium term. Importantly, the Government's reform program has attracted broad support politically, amongst the local business community and within civil society.

The sentiment of the President's address is captured in the program's macroeconomic projections, which show that - through adherence to their comprehensive economic reform program and with the support of the international community - Seychelles' GDP is expected to contract slightly in 2009 before staging a recovery from 2010, inflation is forecast to peak in the second quarter of 2009 before declining steadily over the projection period, and the current account balance is projected to improve significantly from 2009.

As the above reforms take hold and macroeconomic stability is restored, the Government will increasingly focus on addressing structural impediments to Seychelles' growth and development. The authorities are working with the IMF, World Bank and African Development Bank on developing a comprehensive medium-term structural reform program. Once this work is finalised, the Government intends to request a longer-term engagement with the Fund under a successor Extended Fund Facility arrangement. 
Finally, my Seychellois authorities would like to thank the Managing Director, Deputy Managing Director Kato and Ms. Sayeh for their support. They also extend their deepest gratitude to the IMF's Mission Chief, Mr. Paul Mathieu, and his team for their hard work and dedication in assisting the design of Seychelles' economic reform program. 